\title{
Index for Volume 100
}

AUTHOR AND SUBJECT INDEX. Page numbers of errata are in italic.

Abad, J. A., S1, S173

Abad, Z., S150, S153

Abad, Z. G., S150

Abbas, H. K., 532, S1

Abbasi, P. A., S1

ABC transporters, Cercospora coffeicola on coffee and, S121

Abd-Elgawad, M. M., S1

Abdelkarim, M. M., S2

Abel, C. A., S1

Abeywickrama, K., 1057

Abies balsamea, climate change and tree dieback and decline in Maine, S195

Ablova, I. B., S65

Abonyi, F., S51

Abou Ghanem-Sabanadzovic, N., S2, S112

Abou Tabl, A., S176

Abouzeid, M., S34

Abrahamsen, U., S36

Abrameit, A., S54

Abramova, S., S207

Abril, M., S134

Abscisic acid

Fusarium oxysporum on melon and production of, modification by Trichoderma harzianum and Glomus intraradices, 682

and Phytophthora capsici infection, S104 and Phytophthora spp. on tomato and chrysanthemum, salt-induced susceptibility, 871 and resistance of rice against Rhizoctonia solani, S146

Acacia koa (koa), Fusarium oxysporum on, in

Hawaii, S118

Acanthorhynchus vaccinii, on cranberry, S101

Accinelli, C., S1

Acevedo, M., 511, S45

Achar, P., S2

Achenbach, U. C., S15

Acholeplasma palmae, Acholeplasmavirus P1 from, S29

Acholeplasmavirus P1, from Acholeplasma palmae, S29

Achor, D. S., 756, 949

Acibenzolar

and systemic acquired resistance against Xanthomonas citri subsp. citri, $\mathrm{S} 42$

for Xanthomonas fragariae on strawberry, S83 for Xanthomonas perforans on tomato, S178 for Xanthomonas sp. on shrub rose, S177

Acidovorax spp.

A. avenae subsp. citrulli

on cucurbits, survival in stored seeds, S200 quorum sensing, virulence and seed-toseedling transmission, S148

on watermelon, effect of mechanism of infestation on localization, S148

A. citrulli, PAMDB and, 208

Acosta, T., S96

Acosta-Leal, R., 127, S2, S120, S149

Acremonium zeae, on maize, interactions with Aspergillus flavus, $\mathrm{S} 137$

ACTTS2 (ACT-toxin synthesis) gene, of Alter-

naria alternata, and pathogenicity, 120

Adams, G. C., 337

Adams, I., S154

Adaptive cluster sampling, for estimating plant disease incidence, 663

Adaskaveg, J., S2, S163, S166

Adaskaveg, J. E., 738, S141

Adelfinskaya, Y., S63

Adhikari, T. B., S3, S45, S76

Adjuvant, fungicide performance assessment and, S142

Adkins, S., 1194, S70, S134
Adkison, H., S129

ADON (acetyl-deoxynivalenol). See Deoxynivalenol

Adult-plant resistance, of wheat against stripe rust, identification of genomic regions controlling, 313

Aflatoxin

from Aspergillus spp.

A. flavus: effect of varying sugar concentrations on, S128; on maize, S37, S96; variation in competitive ability among isolates, 150; in vivo vs. in vitro production of, $\mathrm{S} 103$

PCR detection of in corn and red flour beetle, $\mathrm{S} 29$

in corn

in Nigeria, mitigation with atoxigenic strain mixes, $\mathrm{S} 8$

tillage management and, $\mathrm{S} 1$

partnerships for biological control of, S162

Agaricus bisporus (button mushroom), global expansion in gourmet and medicinal cultivation, S163

Agdia, Inc., Phythophthora ramorum detection in field within 30 minutes, S15

Aggregate sheath spot, Rhizoctonia oryzae-sativae on rice, population structure of in California fields, 493

Agilent GeneChip Array, for Candidatus Liberibacter on citrus, S61

Agindotan, B. O., S3

Agra, O., S33

Agrobacterium tumefaciens, on walnut seeds used for rootstock production, $\mathrm{S} 141$

Agrostis stolonifera (creeping bentgrass)

Anguina agrostis on, effect of aging on survival and heat tolerance, S206

chlorothalonil and iprodione residues on, ELISA kits for, S64

isoparaffin-based oil for controlling dollar spot and gray leaf spot in, S208

Aguayo, J., 1262

Agyemang, P. A., S3

Ahn, K., S97

Ahonsi, M. O., S3

Aime, M. C., S113

Ajiro, N., 120

Akimitsu, K., 85, 120

Akridge, J. R., S46

Al Rwahnih, M., S3

Alabi, O. J., 698, S3, S101

Alananbeh, K. M., S182

Albacete, A., 682

Albugo candida, on canola, host-pathogen interactions, S60

Alder, Phytophthora alni on, model for detection of asymptomatic infectious individuals, 1262

Aldrich-Wolfe, L., S4

Alexandrova, A. V., S64

Alezones, J. M., S4

Al-Hamdany, M., S4

Ali, A., S4

Ali, M. B., S38

Ali, S., S4

Alishiri, A., S4

Alkharouf, N. W., S127

Allelopathy, sorghum, impact of mycorrhizal infection on sensitivity of wheat to, $\mathrm{S} 2$

Allen, C., S22, S55, S66, S115, S173

Allen, P., S30

Allen, R., S110

Allen, T. W., S5, S49, S112

Allium spp.

bacterial diseases on, in Pennsylvania, S195
A. cepa (onion)

bacterial diseases on, in Pennsylvania, S195

multiplex PCR for simultaneous detection of eight pathogens in, S77

Pantoea ananatis on, transposon mutagenesis of for isolate with reduced virulence, S144

Phoma terrestris on, fungicide dip treatments for, S113

A. sativum (garlic)

Fusarium proliferatum on, fusaric acid production and, S95

Sclerotium cepivorum on, in Maine, S194

D-Allose, 85

Almeida, R., S62

Almeida, R. P. P., 830

Almeyda, C. V., S5

Almond. See Prunus dulcis

Alrwahnih, M., S5

Alternanthera mosaic virus, and vectors for virusinduced gene silencing and protein expression, S71

Alternaria spp.

A. alternata

ACTTS2 gene of, and pathogenicity, 120

on citrus, $\mathrm{S} 85$

increasing carbon dioxide and sporulation of, $\mathrm{S} 208$

on Japanese pear, reactive oxygen species generation and penetration of appresoria, 840

rapid screening for fungicide resistance, S130

on tangerine, S6, S174

on tomato, $\mathrm{S} 33$

A. brassicicola, transcription factors in pathogenicity of, $\mathrm{S} 25$

A. solani

on potato, $454, \mathrm{~S} 14$

synergistic agents for, reduction of resistance and health risks, S61

on tomato in North Carolina, S55

A. tagetica, on marigold, S46

on Vaccinium meridionale., S19

Altland, J. E., S74

Altosaar, I., 848

Alvarado-Hernandez, M., S5

Alvarez, A., S86

Alvarez, A. M., S66, S78, S96, S98

Alvarez, E., S5

Alvarez-Medina, A., S6

Alves, E., S36

A.-M. Simao-Beaunoir, 91

Amaku, M., 1042

Amaradasa, B. S., S6, S152

Amaranthus cruentus, Choanephora cucurbitarum on, in Nigeria, S9

Ambrosia asymptomatic virus 1 (AAV-1), from

Tallgrass Prairie Preserve in Oklahoma, sequence data, $\mathrm{S} 121$

American chestnut. See Castanea dentata

American Phytopathological Society

creation of, 14

Office of Science and Technology Policy fellowship, S168

opportunities for funding and regulatory policy priorities, $\mathrm{S} 167$

Ames, K. A., S191

Ametoctradin

as oocyte-specific fungicide, $\mathrm{S} 63$

for Phytophthora spp., S90

Amini, N., S6

Aminian, H., 454 
Ammar, E., S6, S27, S184

Ammar, E.-D., 1138

Amorim, L., S41, S118, S119

Ampelomyces spp., for biocontrol of Erysiphe

necator on grapevine, $\mathrm{S} 19$

Amsden, B. F., S6

Amyotte, S., S64

Anaerobic soil disinfestation, for bell pepper/eggplant crop production, cover crop carbon sources for, S19

Ananas comosus (pineapple), Dickeya sp. on antibody-binding properties and seasonal disease severity indices and, S98

introduction of to Hawaiian plantations, S78

Ananthakrishnan, G., 1077

Anchieta, A., S64

Anco, D. J., S6

Ancona, V., S7

Anderson, A. J., S158

Anderson, C., S177

Anderson, G., S11

Anderson, G. M., S66

Anderson, K. G., 279

Anderson, K. M., 279

Anderson, R., S158

Andreote, F. D., S35

Andrews, D. L., S98

Andrews, K., S9

Anguina agrostis, on creeping bentgrass, effect of aging on survival and heat tolerance, S206

Anjou pear. See Pyrus communis

Annamali mixture, for control of pathogens on mung bean, S129

Annual bluegrass. See Poa annua

Annular rings, for enhancing photographs of perineal patterns of root-knot nematodes, S32

Anthocyanins, Grapevine leafroll-associated virus-3 in grape and, S45

Antigliani, V., S158

Antimicrobials, production by endophytic bacteria, S38

Antolínez, C. A., S7, S29

Antoun, H., S193

Anu, A. E., S117

Aoki, T., 58, 1176

Aphanomyces cochlioides, on sugar beet in Michigan, S47

Aphids, and Cereal yellow dwarf virus-RPV in oat, S100

Aphis glycines, and transmission and evolution of soybean dwarf virus, $\mathrm{S} 126$

Apium graveolens (celery), Apium virus $Y$ in, biological characterization and complete genome sequence, $\mathrm{S} 140$

Apium virus $Y$ (ApVY), in celery, biological characterization and complete genome sequence, S140

Appel, D. N., S7

Apple. See Malus $\times$ domestica

Apple dimple fruit (ADFVd) and Apple fruit crinkle (AFCVd), multiplex real-time RT-PCR assay for simultaneous detection of four viroids and, S72

Apple proliferation (AP) disease

Candidatus Phytoplasma mali and, 863

phloem cytochemical modification and gene expression after recovery from, 390

Apple scar skin (ASSVd), multiplex real-time RT-

PCR assay for simultaneous detection of four viroids and, S72

APS Public Policy Board safety initiative, S155

Arabidopsis spp.

coronatine-dependent suppression of innate immunity in guard cells, S91

Pseudomonas syringae pv. tomato on, stomate-based defense against, S24

A. thaliana

clusters of disease-related genes in genome of, S208 soybean cyst nematodes on, characterization of bHLH transcription factors induced in, S187

Xylella fastidiosa on, ecotypes with differential susceptibility, S110

Turnip mosaic virus in, differential regulation of host mRNA translation initiation, S188

WRKY proteins and responses to biotic and abiotic stress, $\mathrm{S} 47$

Arabis mosaic virus (ArMV)

on grape in Iran, S31

on rose, chemo-thermotherapy for control of, S84

Arachis hypogaea (peanut)

Aspergillus section Nigri on, S10

Cercospora arachidicola on, S105, S200

Cercosporidium personatum on, S200

cylindrocladium black rot of, S100

impact of cropping sequence on, cotton, corn and, S20

Puccinia arachidis on, $\mathrm{S} 8$

sampling for pod rot of, S136

Sclerotinia minor on, S204

Sclerotium rolfsii on, S40, S199

soilborne pathogens causing pod rot of, in

New Mexico, S114

Tomato spotted wilt virus in, $\mathrm{S} 105$

Verticillium dahliae on, S204

Arai, M., 612

Araujo, L., S122

Araújo, W. L, S35, S77

Arauz, L. F., 959

Arbuscular mycorrhizal fungi

effect of cropping systems on community diversity and structure, S57

and Phytophthora spp. on pistachio in Iran, S85

on tomato, effect of cropping systems on community diversity and structure, S173

Areca catechu (betel nut), Phytophthora palmivora on, phosphoric acid application and, S178

Arellano, C., 72, S114

Arevalo, H. A., S77

Arevalo Zelada, J., S125

Arias, M. M. Díaz, 345

Arif, M., S7, S19, S30

Aritua, V., S7

Armillaria mellea, genetic diversity patterns and population structures of, 708

AroQ $\gamma$ chorismate mutase, in Xanthomonas oryzae pv. oryzae, and rice virulence, 262

Arredondo, F., S158

Arrellano, C., 719

Arriaga, F. J., S16

Arrieta, M. L., S8

Arul, J., S65

Asalf, B., 246, S8

Asano, S., 436

Ascochyta rabiei, on chickpea, penthiopyrad for, $\mathrm{S} 125$

Ascophyllum nodosum, for Fusarium spp. on cucurbits, S18, S205

Ashizawa, T., 612

Ashton, P., S154

Asian citrus psyllid. See Diaphorina citri

ASM (acibenzolar-S-methyl), induced systemic resistance and, $\mathrm{S} 165$

Asparagus, Phytophthora asparagi on, in Michigan, S176

Aspergillus spp.

aflatoxin-producing strains, PCR detection of in corn and red flour beetle, S29

A. flavus

aflatoxin production, $\mathrm{S} 8, \mathrm{~S} 103, \mathrm{~S} 128$

and Aspergillus parasiticus, heterokaryon incompatibility, S85

crop rotation and persistence of atoxigenic strain of, S55 host and life strategy adaptations, and competition among isolates, $\mathrm{S} 81$

inhibition of by Pseudomonas spp., and decreased airborne spore dispersal, 532

on maize: and aflatoxin, mitigation with atoxigenic strain mixes, S8; interactions with Acremonium zeae, S137; kernel maturation and transcriptional activity, S108; lipoxygenases and aflatoxin accumulation, S96; mycotoxins from, $\mathrm{S} 4$; resistance against, S37; at-tassel fungicide application and, S49; variation in competitive ability among isolates, 150

mating between cryptic species I and II, S28

mycotoxin diversity in, $\mathrm{S} 157$

response to sublethal atmosphere of ozone, S138

sexual reproduction of, $\mathrm{S} 92$

soil vs. corn kernel populations, S124

vegetative compatibility groups of, $\mathrm{S} 43$

A. parasiticus

and Aspergillus flavus, heterokaryon incompatibility, S85

mycotoxin diversity in, S157

phylogenetic relations, host adaptation, and global transport of, S39

on peanut, detection of toxin and non-toxin

forms of, $\mathrm{S} 2$

section Nigri, S10, S95

Aster leafhoppers. See Macrosteles quadrilineatus

Aster yellows phytoplasma, influence of time,

host plant, and location on diversity of, S33

Atalantia ceylanica, Candidatus Liberibacter asiaticus on, S107

Atallah, Z. K., 1222, S8, S24, S64, S79

Atehnkeng, J., S8

Athinuwat, D., S8

Atiri, G. I., S113, S126

Auge, R. M., S44

Augusto, J., S8, S199

Aureobasidium pullulans, for brown rot blossom

blight of sour cherry, S51

Austerweil, M., 367

Autio, W. R., S197

Auxin, and bacterial production and turnover, S158

AV2 protein of, of Tomato yellow leaf curl China

virus as silencing suppressor, S139

Avant, J. B., 484

Avanzato, M., S111

Avena spp.

A. barbata, Puccinia coronata on, and resistance, broad-spectrum, sources, S21

A. sativa (oat)

Cereal yellow dwarf virus-RPV in, $\mathrm{S} 100$

fungicides for control of crown rust on, S46

Puccinia coronata on, 484, 511

Avenot, H. F., S9

Avila, L. L., S9

Avirulence genes

of Magnaporthe oryzae, 436, 612, S204

Pseudomonas syringae on potato, $\mathrm{S} 23$

Pseudomonas syringae on soybean, S106

Xanthomonas oryzae pv. oryzae and, S159

Avis, T. J., S193

Avocado. See Persea spp.

Awurum, A. N., S9

Ayodele, M., S117

Ayres, A. J., S74

Azelaic acid, priming plant defense and, S160

Azevedo, J., S35

Azospirillum brasiliense, for control of Ustilago scitaminea, S111

Azoxystrobin

for Cercospora sojina on soybean, S145

for Rhizoctonia solani on sugar beet, S48, $\mathrm{S} 102$ 
Babadoost, M., S9, S108, S126, S190, S191, S196

Babujee, L., S55

Baccari, G. V., S60

Baccharis sp, influence of fallow soil period on,

in Bolivian highlands, S41

Bacillus spp.

B. cereus, endophytic vs. strains causing foodborne illness, $\mathrm{S} 82$

for inhibition of Magnaporthe oryaze, S106

B. mojavensis, substrate and surfactin production by, $\mathrm{S} 10$

B. mycoides, for Fusarium spp. on wheat, S87

B. pumilus strain INR-7, S165

in rhizosphere of potato, as PGPR inoculants

for improved production, S20

B. subtilis

for control of gray mold on tomato and powdery mildew on cucumber, S70

for control of Plasmodiophora brassicae on canola, S99

for control of Verticillium dahliae on cotton, S75

lipopeptide production by, source of polypeptone in culture and, S143

M36, for Fusarium solani f. sp. phaseoli, S84

MBI 600, S65

QST 713, S131, S165, S195

B. thuringiensis $(\mathrm{Bt})$ proteins, in corn, for pest management, $\mathrm{S} 183$

Backup, P., S17

Backus, E. A., S9

Bacon, C., S10, S147

Bacon, C. W., S10

Bactericera cockerelli (potato psyllid)

and Candidatus Liberibacter solanacearum on potato in Texas Panhandle, S50

detection of Candidatus Liberibacter spp. in, S77

Bacteriophages, for biological control of Pseudomonas solanacearum and Xanthomonas campestris on tomato, S34

Badebo, A., S93

Badiani, M., 390

Baek, J.-M., 502

Baenziger, P., S134, S191

Baeza-Montañez, L., S98

Bag, S., S10

Bagewadi, B., S10, S154

Bai, G., 468

Bai, Y., S72

Baier, K., S10

Bailey, D. J., 1169

Baillieul, F., 424

Bajwa, S., S31

Bakker, P., S165

Bakker, P. A. H. M., 404

Bala, K., S150, S153

Balakrishnan, N., S101

Balci, Y., S151

Baldwin, T., S147

Baldwin, T. T., S10

Balint-Kurti, P., 72, S11, S114

Balkcom, K. S., S16

Balla, B., S51

Banana. See Musa spp.

Bandyopadhyay, A., S11

Bandyopadhyay, R., S8, S117, S128, S162, S190

Banihashemi, Z., S85

Banu, S. P., S11

Bao, Y., 822

Barak, J., S47, S155, S168

Barash, I., 252, S22

Barbara, D., S64

Barber, B., 979

Barbetti, M., 551, S35, S39, S60

Barbosa, J. C., S11, S87

Bardsley, S. J., S11

Barham, J. D., S153
Baring, M. R., S204

Barley. See Hordeum vulgare

Barley net blotch, differentiation of Pyrenophora

teres f. teres from P. teres f. maculata and, 1298

Barnes, J. S., S131

Barney, W., S126

Barooti, S., S83

Barouti, S., S84, S124

Barphagha, I., S47

Barrera, W., S12

Barros, N., S121

Barry, K. C., S160

Barthe, G. A., S86

Bartz, J., S33

Bartz, J. A., S12

Bar-Zvi, D., 271

Basart, J. P., S188

Bascur, G., S99

Basil. See Ocimum spp.

Baskin, D., S200

Bass, J., S103

Bassanezi, R., S200

Bassanezi, R. B., S74

Bastas, K., S12

Basu Thakur, P., S12

Bates, A. A., S53

Batson, W. E., S153

Batuman, O., S12

Batzer, J. C., 345, S15, S54, S112, S189

Baudoin, A. B., S12

Baughman, T. A., S204

Baum, T., S58, S141, S187

Baum, T. J., S116, S132, S179, S186, S187

Baumgartner, K., 708

Bautista, N., S89

Bayon, C., S12

Baysal-Gurel, F., S13, S20, S124

Bcl-2-associated athanogenes (BAG), in Arabi-

dopsis and unfolded protein response, S58

BDM1 gene, Fusarium graminearum virulence and, S52

Bean. See Phaseolus vulgaris

Bean, mung. See Vigna radiata

Bean leaf beetle. See Cerotoma trifurcata

Bean leaf roll virus (BLRV), molecular charac-

terization and ELISA-based detection of, S130

Bean pod mottle virus (BPMV)

in soybean, S123, S183, S205

vector systems from for exploration of soybean cyst nematode-plant interactions, S187

Beattie, A. C., S74

Beattie, G. A., S136

Beaudoin, N., 91

Beaulieu, C., 91

Becher, R., 444

Becker, J. O., S141

Becker, K., S158

Beckerman, J., S23, S69, S189

Beckerman, J. L., S168, S183

Bednarek, P., S158

Beer, S. V., S144

Beet curly top virus (BCTV), in bean, QTL responsible for resistance to, 972

Beet necrotic yellow vein virus (BNYVV)

evolution of for overcoming host resistance, S149

host effect on genetic diversification of singleplant populations, 1204

resistance-breaking variants of in nature, $\mathrm{S} 2$ in sugar beet, $127, \mathrm{~S} 120$

Beggarweed. See Desmodium tortuosum

Behlau, F., S13, S172

Behn, J. L., S182

Beirn, L. A., S13, S193

Bejarano, J. C., S13

Beladi, S., S13

Bélanger, R., S198

Bélanger, R. R., S196

Belasque, Jr., J., S11
Belcher, A., S114

Belcher, A. R., S14

Belknap, W. R., S101

Belonalaimus longicaudatus, Pasteuria usgae for control of, S199

Beltrán, C., S42

Beltrão, R., 199

Belzile, F., S196

Bemisia tabaci (tobacco whitefly), and Cucurbit

chlorotic yellows virus, in cucumber and melon, 560

Ben Kalifa, H., S33

Ben-Daniel, B., 271

Benincasa hispida (winter gourd), evaluation of cover crops with, S133

Benlate, banana and, S170

Bennett, A., S167

Bennett, M. H., S70

Bennett, P. J., S33

Bennetzen, J., S40

Benomyl, for Erysiphe necator, resistance against,

S12

Benson, M., S94, S102

Benson, M. M., S90

Bent, A. F., S26

Bentgrass, creeping. See Agrostis stolonifera

Bentley, C., S94

Benzimidazole

for Botrytis cinerea on rose, prevalence of resistance against, $\mathrm{S} 62$

for Venturia inaequalis on apple, molecular and mycelium assay for resistance, S189

Benzothiadiazole, for Phytophthora infestans on tomato, mechanisms of resistance, S147

Berberis spp., as alternate host for Puccinia striiformis, 432, Cover photo May

Berestecky, J. M., S98

Bergamin Filho, A., S11, S78, S200

Bergemann, S. E., 708

Berger, P. H., S156

Bermudagrass. See Cynodon spp.

Bernal, A., S8, S127

Bernal, A. J., S7, S21, S22, S29, S39, S86

Bernardes-de-Assis, J., 172

Berner, D. K., S64, S205

Bernier-English, V., S193

Berry, S. A., S189, S192

Berta, G., 805

Bérubé, M., S193

Bestor, N. R., S14, S182

Beta vulgaris (sugar beet)

Beet necrotic yellow vein virus in, 127, S120

causes of seedling damping-off in Michigan, S47

Fusarium spp. on, in Iran, S13

Heterodera schachtii on, S108, S136

Leuconostoc mesenteroides subsp. dextranicum on, $\mathrm{S} 123$

Rhizoctonia solani on

AG 2-2 isolate, S16

azoxystrobin for, S48, S102

cultivar selection for resistance, $\mathrm{S} 123$

temperature, moisture, and fungicide effects in managing, 689

soybean cyst nematode on roots of, S111

Betasatellite, Tomato yellow leaf curl virus and, S53

Betel nut. See Areca catechu

Bextine, B. R., S115, S116

Beyer, D., S164

Bhat, R. G., S115

Bhat, S., S142

Bhattacharyya, M. K., S80, S183

bHLH genes, and soybean cyst nematodes on

Arabidopsis thaliana, S187

Bi, J., S118

Bi, Y., 1162

Bian, W., S60

Biasoli, M., 58 
Bienapfl, J. C., S14

"Big Box" retail stores, overview of potted plant wholesale production business of, S161

Biggs, A. R., S56

Bigirimana, J., 262

Bilodeau, G., S14

Bindschedler, L., S56

Biochar, induction of systemic resistance by, 913

Biocontainment security, USDA-APHIS permitting and, S61

Biodisinfection, for control of Fusarium oxysporum f. sp. dianthi on carnation, S39

Bioenergy crops

corn for ethanol production, Fusarium toxins in, S180

Miscanthus $\times$ giganteus

plant diseases in, S180

potential viral threats to in United States,

response to fungal pathogens, S17

plant diseases in, S180, S181

Pratylenchus spp. associated with, S74

sorghum

alteration of lignin biosynthesis and $\mathrm{Fu}$ sarium spp., 631, S37

disease and yield evaluation, S16

plant diseases in, S180

switchgrass

improvement of root, microbe, and soi interactions for enhanced value of, S40

plant diseases in, S180

potential viral threats to in United States,

Biofilms

lipopolysaccharide biosynthetic genes of Xanthomonas axonopodis pv. citri and, S71 Xylella fastidiosa and, S28, S72

Bioherbicides, commercialization of, S162

Biological control

of aflatoxin, partnerships for, S162

Ampelomyces spp., for Erisyphe necator, S19

Aureobasidium pullulans for brown rot

blossom blight of sour cherry, S51

Bacillus spp. for

B. mojavensis surfactant, and antagonistic response to Fusarium verticillioides, S10 induced systemic resistance and, S165

B. mycoides, for Fusarium spp. on wheat, S87

B. pumilus, for Erwinia tracheiphila on cucumber, S165

B. subtilis: for Fusarium solani f. sp. phaseoli, S84; for gray mold on tomato and powdery mildew on cucumber, S70 induced systemic resistance and, S165 for Rhizoctonia solani, S65; soil application for disease control, yield improvement, and quality enhancement, S131; for Verticillium dahliae on cotton, S75

Brassica spp.

evaluation of greens of for nematode control, S123

for Phytophthora capsici on cucurbits, S126, S142

of brown rot on peach, integration of biofungicides and conventional fungicides, S195

Burkholderia spp. and, identifying genes related to, $\mathrm{S} 77$

challenges and successes of registration process, $\mathrm{S} 162$

of Choanephora cucurbitarum on amaranth, in Nigeria, S9

Chondrostereum purpureum, for control of woody invasive plant species, $\mathrm{S} 102$

Colletotrichum gloeosporioides for, S162, S205

of Colletotrichum orbiculare on cantaloupe, S35 compost water extracts for control of Phytophthora capsici on pepper, 774

Coniothyrium minitans, for Sclerotinia sclerotiorum, temperature and UV radiation and, S5

of control of nematodes and soil-borne disease

in vegetable production, $\mathrm{S} 50$

DAPG, for pseudonomonads, S116

of disease on tomato, S196

effect of climate change on plant-pathogenbeneficial organism interactions and, S33

essential oils for control of Phytophthora capsici, $\mathrm{S} 60$

fish emulsion for potato scab suppression, $\mathrm{S} 1$

Fusarium isolates, for control of bean broom-

rape and hemp broomrape, $\mathrm{S} 34$

of Fusarium spp.

on cucurbits, S18, S205

F. oxysporum, S13, S129, S146

F. solani, $\mathrm{S} 84$

Gliocladium virens strain GL-21, for Sclerotinia spp. on lettuce, S91

Gymnoascus reessii for control of root-knot nematode, S105

Herbaspirillumn seropedicae and Azospirillum brasiliense for control of Ustilago scitaminea, $\mathrm{S} 111$

herbicides for, SARRITOR and Collego, S162

induced systemic resistance and, S165

inhibition of Aspergillus flavus by Pseudomonas spp., and decreased airborne spore dispersal, 532

of Macrophomina phaseolina on sunflower, in Pakistan, S128

modeling efficacies of pathogens in relation to characteristics of biocontrol agent, 814

mulch, bio-enhanced organic for control of nutsedges in tomato, S176

Myrothecium verrucaria for, and effect of surfactants on conidial germination, S57

of nematodes and soil borne diseases in fruiting vegetables, MeloCon WG and SoilGard $12 \mathrm{G}$ used as methyl bromide alternative, S200

Pantoea vagans $\mathrm{C} 9-1$ complete genome sequence of, S120 for control of fire blight, 1330, S54, S59

Pasteuria usgae, for control of Belonalaimus longicaudatus, S199

of Plasmodiophora brassicae on canola, Bacillus subtilis and Gliocladium catenulatum for, S99

poultry litter for control of Sclerotium rolfsii, S103

of powdery mildew on cucurbits, S80

of powdery mildew on zinnia, S74

of Pseudomonas solanacearum and

Xanthomonas campestris on tomato, S34

Pseudomonas spp. for

for control of Gaeumannomyces graminis var. tritici on wheat, S14

P. fluorescens a506, for fire blight, 1330

P.chlororaphis O6, induced systemic resistance and, bacterial determinants, S158

Pseudozyma flocculosa for powdery mildews, mechanism of action, S198

of Ralstonia solanacearum on ginger, screening for agents for, S141

redefining paradigm of, S159

Regalia, for control of cucumber powdery mildew and lettuce downy mildew, synergistic effect with other fungicides, $\mathrm{S} 123$

of Rhizoctonia solani on rice, screening for agents for, $\mathrm{S} 146$

of root-knot nematode on tomato in Egypt, S1

S1Pf1Rif from Pseudomonas putida against chrysanthemum yellows phytoplasma infection of, 805

of Salsola tragus, searching for fungal agents for, S64
Simplicillium lanosoniveum, for control of Phakopsora pachyrhizi on soybean, S134

of Sphaerotheca xanthi on squash, evaluation of agents for, S145

Streptomyces lydicus for Fusarium oxysporum f. sp. niveum on watermelon, S51

Synchytrium solstitiale for control of yellow starthistle, S34, S206

Trichoderma spp.

elicitor proteins and, S27

T. harzianum, 1213, S60, S124

overview of, S165

in vitro evaluation against fungal trunk

disease pathogens in Mexico, S101

Ulvan, for Colletotrichum gloeosporioides on apple, $\mathrm{S} 122$

using Lysobacter enzymogenes, S98

of Verticillium dahliae on cotton, screening for agents for, S140

of Xanthomonas spp. on tomato, evaluation of agents for, $\mathrm{S} 145$

of Xylella fastidiosa on grapevine, S52

Biosecurity. See Food security

Bipolaris spp.

on Cordyline spp., S125

on rice, mapping genes for resistance to, $\mathrm{S} 11$

Bird, G., S185

Birren, B., S64

Bispyribac-sodium, for annual bluegrass control and brown patch in tall fescue, $\mathrm{S} 28$

Bittner, R. J., S14

Björkman, T., 1213

Black raspberry. See Rubus occidentalis

Black raspberry necrosis virus, thermotherapy for elimination of, S56

Black sigatoka. See Mycosphaerella fijiensis m

Black vine weevil, on strawberry, evaluation of breeding lines for tolerance, S195

Black walnut. See Juglans nigra

Blackberry, Marafivirus sp. in, S112

Blackberry yellow vein associated virus

(BYVaV), epidemiological studies on, S103

Black-faced leafhopper. See Graminella nigrifrons

Blaedow, R. A., 979

Blair, J. E., 732

Blaser, J. M., S15

Blazheva, D., S30

Block, C. C., S188

Blok, W., 593

Blomquist, C. L., S14

Blueberry. See Vaccinium spp.

Bluegrass. See Poa spp.

Bluhm, B., S142

Bluhm, B. H., S35, S52, S109, S120, S148

Blumeria graminis on barley, 21, S158

type III secretion system of Xanthomonas for screening for effectors of, S56

on wheat, oligogalacturonides and defenses induced in, 1352

BNYVV. See Beet necrotic yellow vein virus

Bock, C. H., 1030, S15

Bockelman, H., S65, S104

Bockus, W., 468

Bockus, W. W., S45

Bocsanczy, A., S15

Boehm, M. J., S33

Boerma, H. R., S61

Bogdanove, A., S56

Bogdanove, A. J., S159

Bohannon, R. C., S15, S143

Bohlmann, H., S117

Boland, G. J., S17

Bolton, M. D., 689, S102, S111

Bonasera, J. M., S144

Bond, J. P., S191

Bondalapati, K. D., S15

Bonde, M. R., S16 
Bonman, J. M., 484, 511, S3, S45

Bonn, G., S116, S172

Bonnot, F., 300

Bonos, S. A., S193

Boonham, N., 143, S154

Boquet, D. J., S115

Bordovsky, J. P., S138

Borenshtein, M., 913, S33

Borges, B., S4

Borneman, J., S141

Bornstein, M., 97

Borth, W. B., S82

Boscalid

for Botrytis cinerea on apple, S63, S143

for Didymella bryoniae, S9, S201

for Penicillium expansum on apple, S63

Bosco, D., 805

Bost, S. C., 345, S16

Bostock, R. M., 871, S25, S48, S53, S104, S141

Botermans, M., S81

Botryosphaeriaceae

on olive and other hosts in Spain and California, 1340, Cover photo December

on southern highbush blueberry, in Florida, S138

Botrytis cinerea

on apple, S63, S143, S163

and biochar, induction of systemic resistance against, 913

on carrots, S65

on cucumber, S70

on grapevine, $\mathrm{S} 49$

IVR gene and resistance against, 225, 400

on poinsettia, $\mathrm{S} 128$

on pomegranate in Spain, S86

reactive oxygen species, necrotrophy and, S151

on rose, $\mathrm{S} 62$

and signaling in plant host and generalist pathogens, S165

on strawberry, S6, S134

synergistic agents for, reduction of resistance and health risks, S61

on tomato, S33, S70

Bottle gourd. See Lagenaria siceraria

Bottner-Parker, K. D., S69

Bouchard, J., S194

Boulay, M., 424

Bourgeois, G., S193

Bourget, N., S193

Bourland, F. M., S153

Boutanaev, A. M., S208

Bowden, R. L., 904, S41

Bowen, K. L., S16, S20, S128

Boyetchko, S. M., S99

Boyette, D., S162

Bradley, C., S137, S185

Bradley, C. A., S3, S104, S145, S182, S191

Bradley, J., S38

Brady, J., S16

Brady, J. A., S88

Bradysia impatiens (fungus gnats), transmission of Pythium in, 1307

Brancher, N., S99

Brannen, P. M., S16, S199

Bransby, D., S16

Brantner, J. R., S16

Brar, D. S., S11

Brar, H. K., S183

Brassica spp.

as biological control agent

B. alba as cover crop for management of

Phytophthora capsici on cucurbits, S126

evaluation of greens of for nematode control, S123

for Phytophthora capsici on squash, S142

B. juncea (canola)

Albugo candida on, S60

as cover crop for management of Phytoph- thora capsici on cucurbits, S126

Leptosphaeria biglobosa and Leptosphaeria maculans on, S69

recombinant antibody-mediated multiple disease tolerance in, S130

Rhizoctonia solani on, S89

Sclerotinia sclerotiorum on, $\mathrm{S} 184$

seed meal amendment, S134

Leptosphaeria maculans on, screening for resistant lines, $\mathbf{S 7 7}$

B. napus (rapeseed)

Plasmodiophora brassicae on, S99, S194

Sclerotinia sclerotiorum on, inoculation methods for resistance screening, $\mathrm{S} 18$

Plasmodiophora brassicae on, S59

B. rapa (pak choy), Plasmodiophora brassicae on, S74, S117

Sclerotinia sclerotiorum on, population study on Western Australian strains of, S39

Xanthomonas campestris pv. campestris on, detection in seeds, S207

Brauer, K., S183

Braun, S. E., 1307

Braverman, M., S162

Breakspear, A., S75

Breathnach, J., S191

Bremer, D., S91

Bremia lactucae

on lettuce, Revus and Forum for, rainfastness of, S66

Regalia for control of, synergistic effect with other fungicides, $\mathrm{S} 123$

Brennan, J., S17

Brennan, J. M., S17

Brenneman, T., S199

Brenneman, T. B., S8, S199, S200

Brenneria rubrifaciens, on walnut, rpoN and, S80

Brewbaker, J. L., S98

Brewe, C., S108

Brewer, M. T., 1185

Brewster, W. K., S63

Brian, B. K., S2

Bricault, C., S99

Brière, S. C., S197

Britt, R., S58

Brlansky, R. H., 756, 1077, S42, S61, S107, S111,

S143, S172

Brodal, G., S36

Broders, K. D., S17, S33

Bromley, R., 601

Bronstein, P. A., S160

Broome, J. C., S17

Broomrape. See Orobanche spp.

Brose, I. E., S188

Brown, D., S18

Brown, D. W., S18

Brown, J. K., S50, S53, S110, S138, S172

Brown, R. W., S82

Brown, T., S18

Browne, G. T., S115

Bruce, M., S157

Bruckart, W. L., S34, S206

Brueggeman, R., S43

Bruhn, J., 708

Brust, G. E., S18, S205

Bryan, B. K., 127, 1204

Buck, J., S116

Buell, C., S153

Buell, C. R., S127

Bull, C. T., 208, S79

Bunt, and Tilletia spp., survival of secondary sporidia of, 645

Burattini, M. N., 1042

Burbank, L., S85

Burelle, N., S19

Burkett-Cadena, M., S18

Burkholderia spp.

B. andropogonis, hrp system and pthA and pthB from Xanthomonas citri in, S108
B. cepacia complex, broad host rang tailocin from, S31

B. contaminans, occidiofungin production by, occ gene cluster and, S44

B. glumae

novel regulatory genes for virulence factors, S47

on rice, AiiA-mediated quorum-quenching and toxoflavin expression, S96

identifying genes related to biological control of pathogens, S77

Burlakoti, P., S18

Burnham, A. M., S18

Burnquist, W. L., S78

Burr, T. J., S8

Bursaphelenchus xylophilus (pine wood rot nematode), surface coat proteins of, during host pine infection and in vitro culture, 1289

Burskey, C., S39

Bushnell, W. R., 33

Busman, M., S18

Butchko, R., S18

Butler, D. M., S19

Butler, D. N., S90

Byamukama, E., 931, S19, S183

Bylemans, D., S163

BYNVV. See Beet necrotic yellow vein virus

bZIP (basic leucine zipper proteins), in Magnaporthe oryzae, genome-wide functional analysis of, S65

CAA fungicides. See Carboxylic acid amide fungicides

Caasi, D., S7

Caasi, D. J., S19

Caasi, O. C., 415

Cabezas, L. F., S129

Cacao, Moniliophthora perniciosa on, S42

Cacciola, S. O., S76

Cadle-Davidson, L., 1240

Caenorhabditis elegans

attraction of to brown garden snail, S27

for screening bacterial toxins for nematicidal activity, S107

Caesar, A. J., S68

Caesar-TonThat, T., S68

Caetano-Anollés, G., S190

Caffi, T., 1321, S19, S194

Cahalane, G., S17

Cai, R., 208

Cai, X., S19

Calamondin. See Citrofortunella microcarpa

Calcium, Phytophthora nicotianae and, autoregulation of zoospore density-dependent behaviors, 632

Calderon, C., S19

Calibrachoa mottle virus (CbMV), infectious

RNA transcripts from cloned cDNA of, S44

Caligari, P. D., S110

Calla, B., S106

Calle, J., S171

Callow, P. W., S83

Calmodulin, and soybean resistance against

Phytophthora sojae, S107

Calvo-Velez, P., S20

Camacho, F., S29

Camargo, L. E., S21, S74

Camp, A. R., S20

Campa, A., 1315

Campbell, H. L., S20

Campbell, J. H., S199

Campbell, L., 689

Campbell-Nelson, K., S92

CANARY (Cellular Analysis and Notification of

Antigen Risk and Yield) biosensors, S73

Candidatus Liberibacter spp.

$\mathrm{Ca}$. L. americanus

colonization of Cuscuta indecora by, 756 influence of temperature on Asian citrus 
psyllid acquisition of, S11

on orange jasmine and citrus trees in Brazil, S74

Ca. L. asiaticus

bioinformatic analysis of genome strain sequence data for, S72

from citrus relatives, $\mathrm{S} 107$

colonization of Cuscuta indecora by, 756,

Cover photo August

in commercial orchards in Puerto Rico, S34

development of conventional and recombinant antibody screens against, S143

Diaphorina citri and, spread through retail nurseries and garden centers, S46

distinction between Guangdong and Florida using genomic locus with short tandem repeats, 567

distribution in infected citrus trees, S172

and early events of huanglongbing at ultrastructural level, September

expression profiling host response to, S7

in Florida and China, tandem repeat numbers in populations, S24

identification of potential virulence genes in, S122

on orange jasmine and citrus trees in Brazil, S74

organization and structure of two prophage lysogens that become lytic in plant infections, S145

on periwinkle, bactericidal activities of antimicrobial molecules against, S145

salicylate hydroxylase of, S127

in salivary glands and alimentary canal of Diaphorina citri, S6

screening for molecules for control of in periwinkle, 230, Cover photo March sequencing from cultivated cells, S116

SSR-based genetic analysis of isolates from multiple continents, $\mathrm{S} 41$

variation of prophage frequency in strains from different provinces in China, S73

Ca. L. psyllaurous, on potato, $\mathrm{S} 203$

Ca. L. solanacearum

and carrot psyllid on carrot, S88

new method for collection and detection of within host, S103

on potato, S50, S138, S203

on tomato, $\mathrm{S} 173$

zebra chip disease and, S135

on citrus, and Agilent GeneChip Array for gene expression profiling, S61

comparative analysis of reductive genome species, S29

development of primers and probes for realtime PCR detection of, $\mathrm{S} 42$

in Diaphorina citri, detection of, S77

extraction from plants and cultivated cells using pressure cycling technology, S114

new molecular diagnostic tool for quantitating and genotyping, S72

solving inconclusive quantitative $\mathrm{PCR}$ for, S66

Candidatus Phytoplasma spp.

Ca. P. asteris, and witches' broom and dwarfism, S52

Ca. P. mali, on apple multiple infection by distinct strains and pathological relevance, 863 phloem cytochemical modification and gene expression after recovery from, 390

Ca. P. palmae-related strain and, Texas phoenix palm decline and, S175

Canola. See Brassica juncea

Cantaloupe. See Cucumis melo

Cantamessa, S., 805

Canteros, B. I., S13

Cantonwine, E. G., S200
Cao, C., S20

Cao, M., S105

Cape gooseberry. See Physalis peruviana

Capelluto, D. G., S158

Caprara, M., S21

Capsicum chlorosis virus (CaCV-Ph), from

Phalaenopsis orchid, genome sequence of, S146

Capsicum spp. (pepper)

C. acutatum, Colletotrichum acutatum on, S71

C. annuum

Colletotrichum spp. on, S114

electrophoretic potyvirus transfection into protoplasts of, $\mathrm{S} 130$

Phytophthora capsici on, 774, S201

simultaneous detection of two cryptic viruses from, $\mathrm{S} 112$

Tomato spotted wilt virus in, in Taiwan, S53

Xanthomonas perforans on, $\mathrm{S} 103$

Enterobacter cloacae on, S53

Pepper golden mosaic virus in, viral DNA accumulation and, S50

Capsid protein

alteration of amino acid positions, Cucumber mosaic virus transmission and, S99

and Turnip crinkle virus systemic movement in Arabidopsis, $\mathrm{S} 105$

Caragea, P., S188

Carbendazim, for control of Colletotrichum acutatum on citrus, $\mathrm{S} 118$

Carbofuran, for control of root-knot nematode on tomato in Egypt, $\mathrm{S} 1$

Carbone, I., S85, S92, S94, S157

Carboxylic acid amide (CAA) fungicides, resistance of Peronophythora litchii against, 522

Cárdenas, M. E., S21, S22

Cardona, N., S171

Career opportunities after graduate school, S168, S169

Carisse, O., S194

Carlson, B., S21

Carnation, Fusarium oxysporum f. sp. dianthi on, soil biodisinfection for control of, S39

Carnes, M. E., S21, S106

Carpenter, D., S126

Carr, J., S70

Carr, J. P., S147

Carras, M. M., S208

Carrot. See Daucus carota

Carson, M., 432, S21

Carson, M. L., 484

Cartwright, K., S162

Cartwright, R., S145, S202

Cartwright, R. D., S22, S114

Caruano-Yzermans, A., S38

Carvalho, G., S21

Carver, T. L. W., 21

Carya illinoinensis (pecan), Cladosporium caryigenum on, S98

Casassa, L. F., S45

Cassava. See Manihot esculenta

Cassava frogskin disease, S5

Cassell, M. E., S205

Castanea spp. (chestnut)

Cryphonectria parasitica on analysis of transgenic, S89

Cpkk1 and virulence, 1100

ectomycorrhizal colonization, S29

forest restoration and, $\mathrm{S} 167$ resistance against, $\mathrm{S} 10$

selection of transformed somatic embryos of, S91

Castillo, J. A., 208

Castillo, J. D., S21

Castlebury, L. A., S173

Castrillo, L. A., 1307

Castro, A., S110

Castroagudin, V. L., S22

Casuarina equisetifolia (ironwood), decline of in
Guam, S82, S115

Caswell-Chen, E. P., S27, S113

Catal, M., 337

Catch crops, and sugar beet cyst nematode decline, S84

Catharanthus roseus (periwinkle)

Candidatus Liberibacter asiaticus on, 230, Cover photo March, S145

phytoplasma on, $\mathrm{S} 127$

Cating, R. A., S22, S174

Cattaneo, M. G., S136

Cattleya orchids, Phytophthora cactorum on prefinished liners from Thailand, S174

Cavin, C. A., S205

CBF transcription factor family, in Fusarium verticillioides, S109

c-di-GMP biosynthesis genes, of Xylella fastidosa

virulence factors, $\mathrm{S} 7$

Celery. See Apium graveolens

Cell wall degrading enzymes, Ustilago maydis snfl gene as dual regulator of, 1364

Cellier, G., 1250

Cellobiose, and thaxtomin A production, by Streptomyces scabies, 91

Cellulase (celA) gene, Clavibacter michiganensis subsp. michiganensis on tomato, 252

Centaurea solstitialis (yellow starthistle), Synchytrium solstitiale for control of, S34, S206

Center, T. D., S108

Centipedegrass. See Eremochloa ophiuroides

Cepero de García, M. C., S42

Ceratocystis spp.

C. fagacearum, on red oaks, 979

C. fimbriata, on Eucalyptus spp. in Brazil, S35

Cercis canadensis (eastern redbud), redbud yellow ringspot disease and, S201

Cercospora spp.

C. arachidicola, on peanut, $\mathrm{S} 105, \mathrm{~S} 200$

C. coffeicola, on coffee, $\mathrm{S} 121$

C. hydrangeae, on Hydrangea macrophylla, S84

C. kikuchii, on soybean, S22, S26

C. sojina, on soybean, S28, S145, S182

C. zeae-maydis, on corn, S117, S202

C. zeina, on maize, $\mathrm{S} 117$

Cercosporidium personatum, on peanut, S200

Cercosporin, from Cercospora kikuchii on soybean, S22

Cereal cyst nematodes, PCR for distinguishing

Heterodera filipjevi and $H$. avenae, 216

Cereal yellow dwarf virus-RPV (CYDV-RPV), in

oat, and aphid transmission, S100

Ceresini, P. C., 172

Cerotoma trifurcata (bean leaf beetle), and Bean pod mottle virus in soybean, S205

Certification programs

for cantaloupe, S35

for mushrooms, S164

for viruses, S135

Céspedes, M. C., S21, S22

Cha, J., S25

Chaetocnema pulicaria, Pantoea stewartii subsp. stewartii and, type III secretion system, S27

Chaijuckam, P., 502

Chaikam, V., S11

Chakrabarti, A., S75

Chakraborty, S., 1057

Chalupowicz, L., 252, S22

Chaluvadi, S., S40

Chamaecyparis lawsoniana (Port-Orford cedar),

Phytophthora lateralis on, S167

Chambers, A. Y., S153

Champoiseau, P. G., S22, S173

Chanda, A. K., S22

Chandra-Shekara, A., S56

Chang, C., S199

Chang, P. S., S173

Chao, S., S104

Chapara, V., S183 
Chapman, K., S189

Chapman, K. S., S23, S183

Charkowski, A., S19, S78

Charudattan, R., S176

Chatnaparat, T., S103

Chaudhary, P., S185

Chaudhury, A., S23

Chaves, A., S23

Chaves, G., S176

Chawla, S., S200

Chellemi, D. O., S57, S173

Chen, B., S24

Chen, C., S23, S30, S41, S53, S105, S146, S152

Chen, H., S90

Chen, J., 567, S24, S73, S119

Chen, K., S44

Chen, P., S70

Chen, R., S47

Chen, W. Q., 328

Chen, X., S53, S132

Chen, Y., S23, S46

Chen, Z., S22, S37, S39, S47, S64, S96, S164

Cheng, D. M., S72

Cheng, Y., S53

Cheong, E., S56

Cheong, K., S97

Cherry, ornamental flowering, leaf spot disease in, S84

Cherry, sweet. See Prunus avium

Chestnut. See Castanea spp.

Cheung, H. K., S24

Chi, M., S97

chiA genes, as marker for resistance against

Stenocarpella maydis, $\mathrm{S} 88$

Chiampiriyakul, P., S121

Chickpea. See Cicer arietinum

Childers, A. C., S138

Chilling injury, in tomatoes exposed to low

temperature in field, $\mathrm{S} 12$

Chintamanani, S., S11

Chitin

and fungal resistance in Arabidopsis, S68

Xylella fastidiosa virulence and transmission, S62

Chitinase

from Douglas fir seedlings infected with Phellinus sulphurascens, 356

modification of by protein from Stenocarpella maydis, 645

Chitrakar, R., S24

Chitrampalam, P., S24

Chittem, K., S25, S42

Chlorothalonil

for Cercosporidium personatum on peanut, S200

ELISA kits for analysis of residues on creeping bentgrass, $\mathrm{S} 64$

Cho, J., S25

Cho, Y., S25

Choanephora cucurbitarum, on amaranth in

Nigeria, S9

Choi, D., S97

Choi, H.-K., 1089

Choi, J., S25, S97

Choi, Y., S25

Choiseul, J., S17

Chondrostereum purpureum, for control of woody

invasive plant species, $\mathrm{S} 102$

Chong, J., 484, 511

Chorismate mutases, in Xanthomonas oryzae pv. oryzae, and rice virulence, 262

Chou, C., S25

Choudhary, N., S42, S111

CHROMOMETHYLASE 3 (OSCMT3), in RNA

silencing mediated by geminivirus, $\mathrm{S} 90$

Chrysanthemum spp.

bacterial microflora in roots and rhizosphere of, S18, S171

Phytophthora spp. on, abscisic acid and salt- induced susceptibility, 871

Chrysanthemum yellows phytoplasma (CYP), in daisy, 805

Chuaboon, W., S103

Chuma, I., 436

Chung, K., S24

Chunxue, C., S159

Ciaffi, M., 390

Cibils Stewart, X., S26

Cicer arietinum (chickpea)

Ascochyta rabiei on, penthiopyrad for, $\mathrm{S} 125$

Fusarium oxysporum f. sp. ciceri on, genetic diversity of, in Iran, S46

Cilia, M., S100

Cisneros, F. M., S26, S184

Citrofortunella microcarpa (calamondin), Xan-

thomonas anxonopodis pv. citri on, S24

Citrullus lanatus (watermelon)

Acidovorax avenae subsp. citrulli on, S148

Colletotrichum orbiculare on, S146

Didymella bryoniae on, S201

Fusarium oxysporum $\mathrm{f}$. sp. niveum on management with fungicides, S32 resistance of triploid cultivars, S99

Streptomyces lydicus and cover crop for management of, S51

Vicia villosa cover crop for suppression of, S207

Squash vein yellowing virus in, $\mathrm{S} 134$

viruses in single and mixed infections of, 1194

Citrus spp.

C. jambhiri (rough lemon), Candidatus

Liberibacter on, S61

C. paradisi (grapefruit)

Elsinoë fawcetti on, S86

Xanthomonas axonopodis on, S71

Xanthomonas citri on, S15, S36, S116

C. reticulata (tangerine), Alternaria alternata on, S6, S174

C. sinensis (sweet orange)

Candidatus Liberibacter on, S7, S61

Colletotrichum acutatum on, S119

Xanthomonas citri on, S37

Xylella fastidiosa on, disease intensity and yield reduction, in Brazil, S41

Citrus tristeza virus (CTV)

aphid transmitted subisolates, S111

differentiation and identification of potential severe strains, 319

screening global collection of isolates, 1077

Ciuffetti, L. M., S160

Civerolo, E., 567, S24

Civerolo, E. L., S30, S72

Cladosporium spp.

C. caryigenum, on pecan, probability modeling, weather variables as inputs and, S98

C. phlei, increasing carbon dioxide and sporulation of, S208

Clancey, M. S., S188

Clardy, J., S54

Clark, M. M., 493

Clark, W. D., S28

Clarke, B., S90

Clarke, B. B., S13, S109, S193, S197

Clarke, C. R., 208

Clavibacter michiganensis

commercially available ELISA for subspecies, S187

on potato, functional genetic analyses of, S124

on tomato

bacterial virulence and plant defense genes in infection, 252

infection, biofilm formation, and epiphytic fitness, S22

transmission during grafting, S13

visualization using bioluminescent strain, S140

CLE effector proteins, of Heterodera spp. and perception in Arabidopsis roots, S108 trafficking of in plant cells, S132

Cleistothecia, of Podosphaera aphanis, initiation,

development, and survival of, 246

Clément, C., 424

Climate change

Alternaria alternata and Cladosporium phlei sporulation and, S208

food security and, S156

impacts on plant pathogens, S179

metamodels for scaling potato late blight risk and, S121

potato late blight suppression and, S26

tomato, pathogens, and biological control agents and, S33

and tree dieback and decline in Maine, S195

Clinckemaillie, A., S26

Cloropicrin, for Meloidogyne javanica on carrot, S135

Clough, S. J., S106

Cloutier, S., S151

Clover, G. R. G., 1282

Clover, subterranean. See Trifolium subterraneum

Cobine, P. A., S29

Cochliobolus heterostrophus, on maize, S114

Cochliobolus sativus

on barley, S110, S118

MAPK genes in, S69

on wheat, S45, S76

Cochliobolus victoriae. See Helminthosporium victoriae

Cochran, A., S93, S163

Cochran, K. A., S26

Cock, P. J., S80

Cocos nucifera (coconut), lethal yellowing disease of, in Mozambique, spatial and spatiotemporal pattern analysis of, 300

Coffee, Cercospora coffeicola on, cercosporin polyketide synthase, ABC transporter and, S121

Coffey, M. D., 732, S14, S76, S150

Cohen, S., 97, 798

Cohen-Kandli, M., 252, S22

Coles, N. D., 72

Collaboration, of USDA and FDA, S155

Collego, second commercialization of, S162

Colletotrichum spp.

C. acutatum

on blueberry, $\mathrm{S} 83$

on Capsicum acutatum, S71

on citrus, S86, S118

on olive, S86

on strawberry, S21

on sweet orange, S119

C. capsici, on chili pepper, S114

C. cereale, on annual bluegrass, S109, S197

C. coccodes

on chili pepper, S114

genetic diversity of vegetative compatibility groups, $\mathrm{S} 182$

on potato, $\mathrm{S} 93$

vegetative compatibility groups in subpopulations, 271

C. fragariae, on strawberry, S75

C. gloeosporioides

on apple, $\mathrm{S} 122$

for biological control, S162

on blueberry nursery plants, S99

on strawberry, S75, S106

for tumbleweed, S205

C. graminicola

on maize, S19

on sorghum, S16

striatin ortholog of, $\mathrm{S} 133$

C. orbiculare

on cantaloupe, S35

on cucumber, S174

on watermelon, S146

restriction-associated DNA tags for, S27

on strawberry, screening for resistant lines, S83 
C. sublineola, on centipedegrass, S126

Colletto, A., 58

Collins, D. J., S202

Collins, J., 33

ColS/ColR two-component system, and Xanthomonas axonopodis pv. citri virulence, S141

Colyer, P. D., S153

Comparative Fungal Genomics Platform, Fungal

Expression Database and, S97

Competition, modeling of between viruses in complex plant-pathogen system, 1042

Compost water extracts, for control of Phytoph-

thora capsici on pepper, 774

Comstock, J., S78

Comstock, J. C., S106, S173, S175

Comstock, J. P., S26

Conidiation, of Fusarium verticillioides, genes differentially expressed during, S18

Coniothyrium minitans, for control of Sclerotinia sclerotiorum, S5

Conley, S., S67

Conley, S. P., S186

Conner, A. J., 460

Consonni, C., S158

Container plant business, retail stores and, S161

Containment facilities, USDA-APHIS permitting and, S61

Conway, W., S58

Conway, W. S., 42, S56

Cook, D. E., S26

Cook, D. R., 1089, S105

Cooksey, D. A., S118

Cooley, D. R., 345, S195

Cools, H. J., S12, S49

Coop, L., S179

Cooper, G. T., S201

Coplin, D. L., S27, S184

Copper

Xanthomonas citri subsp. citri resistance, S13

for Xanthomonas fragariae on strawberry, S83

CorA transporter, Erwinia carotovora subsp. carotovora virulence and, S61

Coram, T., S53

Corcuff, R., S65

Cordgrass. See Spartina alterniflora

Cordyline spp., Bipolaris sp. on, S125

Corley, J., S126

Corn. See Zea mays

Cornus florida (dogwood), fine scale genetic structure of, S45

Coronatine chloroplast reactive oxygen species and, S54 manipulation of host responses by, S91, S160

Correa, V. R., S27, S184

Correa-Victoria, F., 172

Correll, J., S53, S142, S145

Correll, J. C., S22, S35, S135

Cortez, A., S128

Corynespora cassiicola, on Hydrangea macrophylla, S84

Costa, C. R., S87

Cotes, A. M., S42

Cotes, J. M., S87

Cotton. See Gossypium spp.

Cotton, J. A., S27

Cotty, P. J., 150, S8, S39, S43, S55, S81, S103,

S162

Courtois, J., 1352

Coutinho, F. A. B., 1042

Cover crops

for anaerobic soil disinfestation, in bell pepper/eggplant crop production, S19

Brassica spp. for management of Phytophthora capsici and Fusarium spp. in cucurbits, S190

for control of Colletotrichum orbiculare on watermelon, S146

evaluating for cucumber and winter gourd, S133 for management of Fusarium oxysporum f. sp. niveum on watermelon, S51

Vicia villosa, for suppression of Fusarium oxysporum f. sp. niveum on watermelon, S207

Cover photos

Berberis spp. as alternate host for Puccinia striiformis, May

deoxynivalenol and barley, chloroplast pigments in leaf tissues, January

dodder infected with Candidatus Liberibacter asiaticus, August

early events of huanglongbing at ultrastructural level, September

escudete lesion on olive, Botryosphaeria dothidea and, December

Fusarium mexicanum on mango, mango malformation disease and, November

Fusarium spp. in wheat, cytochrome p450 gene activation and resistance, February

genetic variability of natural populations of Grapevine leafroll-associated virus 2 in Pacific Northwest vineyards, July

Phytophthora capsici on tomato, June

Rhabdocline spp. on Douglas fir variety Shuswap, April

screening periwinkle for molecules for control of Candidatus Liberibacter asiaticus, March

Xylella fastidiosa on grape, Pierce's disease and, October

Covert, S., S59

Cowger, C., 719, S144, S204

Cowles, R. S., S195

Cowpea, viruses in, effect of multiple infections on seed transmission in, $\mathrm{S} 92$

Cox, K., S27, S50

Cpkk1, Cryphonectria parasitica on chestnut, virulence and, 1100

Cranberry. See Vaccinium oxycoccos

Craven, K., S40

Cregan, P., S189

Cregan, P. B., S61

Creswell, T., S69

Crinivirus spp., Cucurbit chlorotic yellows virus, in cucumber and melon, 560

Cronartium ribicola

on Ribes missouriense, causes of seasonal fluctuations in severity, 986

on western white pine, and resistance, S120

on whitebark pine, forest restoration and, S166

Crotalaria juncea (sunn hemp), Golovinomyces

cichoracearum on, S174

Crouch, J., S13, S27, S101, S156, S193

Crow, J., S116

Crull, L., 897

Crutcher, F. K., S27

Cruz, L., S28

Cruz, L. C., S29

Cruz, L. F., S21

Cry proteins, in corn, for pest management, S183

Cryo-electron microscopy, for studies of filamentous plant viruses, $\mathrm{S} 60$

Cryphonectria parasitica, on chestnut, 1100, S10, S29, S89, S167

Csinos, A., S28, S55

Csinos, A. S., S57, S142

Cucumber. See Cucumis sativus

Cucumber green mottle mosaic virus (CGMMV), in cucumber, transmission by pollen, S72

Cucumber mosaic virus (CMV)

2b RNA silencing suppressor of, S70

atomic model of, S99

in Gladiolus spp., S59

nitrocellulose membranes as solid matrix for immunodetection and subgroup identification, $\mathrm{S} 173$

in tobacco, $\mathrm{S} 147$

Cucumis spp.

Acidovorax avenae subsp. citrulli on, survival in stored seeds, S200

Erwinia tracheiphila on, assessing genetic diversity of, S112

evaluation of cover crops with, S133

Fusarium spp. on

Ascophyllum nodosum extract and silicon for, S205

Brassica spp. short-cycle cover crops for management of, S190

F. solani, commercial extracts from Ascophyllum nodosum for control of, S18

management of powdery mildew on with

biopesticides, $\mathrm{S} 80$

C. melo (melon)

Colletotrichum orbiculare on, S35

Cucurbit chlorotic yellows virus in, 560

Cucurbit yellow stunting disorder virus in, S138

Erwinia tracheiphila on, S26, S112, S189

Fusarium oxysporum on, 682

Monosporascus cannonballus and Olpi-

dium bornovanus interactions and, $\mathrm{S} 122$

new potyvirus infecting in California, $\mathrm{S} 12$

Podosphaera xanthii on, S79

Pseudoperonospora cubensis on, S202

Meloidogyne incognita on, identifying and

characterizing resistance to, S35

multiple viruses in single and mixed infections

of, 1194

Phytophthora capsici on

baseline sensitivity to fluopicolide, S201

Brassica spp. short-cycle cover crops for management of, S190

mustard cover crop for management of S126

sensitivity to dimethomorph, cymoxanil, and mefenoxam, S195

variability in ability of isolates to cause disease, S34

Podosphaera xanthii on, in Florida, S40

Pseudoperonospora cubensis on

concentration of airborne sporangia, influence of environment on, S43

effect of temperature and wetness duration on sporulation rate of, $\mathrm{S} 89$

review of fungicides for management of downy mildew, 1066

C. sativus (cucumber)

Bacillus pumilus strain INR-7 for control of Erwinia tracheiphila on, S165

Colletotrichum orbiculare on, S174

Cucumber green mottle mosaic virus in, $\mathrm{S} 72$

Cucurbit chlorotic yellows virus in, 560

Fusarium oxysporum f. sp. radiciscucumerinum on, $\mathrm{S} 95$

Melon necrotic spot virus in, S69, S191

Phytophthora spp. on, S43, S133

Pseudoperonospora cubensis on, 97

viruses infecting in Oklahoma, S4

Watermelon mosaic virus in, 1373

Zucchini lethal chlorosis virus in, $\mathrm{S} 87$

Cucurbit chlorotic yellows virus (CCYV), in

cucumber and melon, 560

Cucurbit leaf crumple virus $(\mathrm{CuLCrV})$

in snap bean in Georgia, S68

in watermelon, in single and mixed infections, 1194

Cucurbit yellow stunting disorder virus (CYSDV) in melon, in California and Arizona, S138

in watermelon, in single and mixed infections, 1194

Cucurbita spp.

C. pepo (squash)

Phytophthora capsici on, S142

Sphaerotheca xanthi on, S145

Podosphaera xanthii on, S139

root knot nematodes on, S31

as rootstock for watermelons, Podosphaera xanthii on, S60 
Xanthomonas campestris pv. cucurbitae on S108

Cuellar, A., S5

Culbreath, A., S105

Culbreath, A. K., S105, S200

CuLCrV. See Cucurbit leaf crumple virus

Cummins, D., S17

Cunniffe, N. J., 638

Cuomo, C., S64, S75, S156

Curly top virus (CTV), in bean, QTL responsible

for resistance to, 972

Curry, A., S134

Curry, K. J., S83, S134

Curtis, M., S104

Curtoviruses, in leafy greens in Arizona, S89

Curvularia lunata, on sorghum, viability staining using tetrazolium violet, S90

Cuscuta indecora, colonization of by $\mathrm{Ca}$. L. asiaticus and $\mathrm{Ca}$. L. americanus, 756, Cover photo August

Cusicanqui, J., S41

Cuticle, in basal and induced defense against

bacterial and fungal pathogens, S139

Cutulle, M. A., S28, S80, S152, S205, S208

Cyazofamid, Pythium aphanidermatum, hormesis and, S36

Cyclins, in Mycosphaerella graminicola, S25

Cylindrocladium spp.

on banana, silicon for control of, S58 on peanut, Propulse for control of, S100

Cymoxanil, for Phytophthora capsici on cucur-

bits, S195

Cynodon spp. (bermudagrass)

Exserohilum sp. on, S57

Ophiosphaerella spp. on, 415, S131

Rhizoctonia spp. on, S152

CYP. See Chrysanthemum yellows phytoplasma

CYP51C gene

from Fusarium spp., for phylogenetic analysis, $\mathrm{S} 35$

of Sclerotinia homoeocarpa, demethylation inhibitor fungicide resistance and, S75

Cyperus spp. (nutsedges), on tomato, bioenhanced organic mulches for, S176

CYSDV. See Cucurbit yellow stunting disorder virus

Cyst nematodes. See Heterodera spp.

Cytochrome b gene (cytb)

and Botrytis cinerea resistance to pyraclostrobin, S143

in Podosphaera clandestina, QoI fungicide resistance and, $\mathrm{S} 73$

Cytokinin biosynthesis, and pathogenesis of Ustilago maydis on corn, S87

Czajkowski, R., 134, 1128

Czosnek, H., 225

da Graça, J. V., S66

da Silva, M. P., S28, S184

da Silva, R., S11

Daane, K., S119

Daane, K. M., 830

Dabala, R. R., S28

Dactylella oviparasitica, from Heterodera schachtii-suppressive soil, S141

D’Agostino, G., 805

Dahlia variabilis, caulimoviruses associated with, S5

Dai, W. D., S18

Daisy, S1Pf1Rif from Pseudomonas putida, against chrysanthemum yellows phytoplasma infection, 805

Dalchau, N., S70

Dally, E. L., S29, S206

Damann, K. E., S28, S124

Damayanti, T. A., S101

D'Amelio, R., 805

D'Amico, K. M., S29

Damsteegt, V. D., S42, S111, S209
Danchok, R. S., S120

Dang, F. J., 183

Dangott, L. J., S27

Danies, G., S7, S29

DAPG

for biological control of pseudomonads, S116 and Phialophora spp., 404

Daros, E., S111

Databases, Microbial Rosetta Stone (MRS)

Central, S59

Datnoff, L., S52

Datnoff, L. E., S36, S174

Datura stramonium (datura), complementation

between viruses in, $\mathrm{S} 10$

Daub, M., S136

Daub, M. E., S121

Daubert, S., S3, S5

Daucus carota (carrot)

Candidatus Liberibacter solanacearum and carrot psyllid, S88

Meloidogyne javanica on, S135

Sclerotinia sclerotiorum on, S100

$\mathrm{UV}-\mathrm{C}$ induced disease resistance and phytoalexin accumulation in, S65

Xanthomonas hortorum pv. carotae on, S139

Daughtrey, M. L., 1307, S90

David, D. R., 913

Davidovitz, M., 798

Davidson, R. M., S157, S164

Davis, E., S141

Davis, E. L., S116, S132, S186

Davis, M., S164

Davis, R. E., S29, S69, S135, S206, S207, S208

Davis, R. F., S202

Davis, R. M., 502, 1222, S53, S153

Davis, T. M., S77

Dawson, W. O., S56, S154

Daylily, Puccinia hemeroca on, effect of light, S31

de Afonseca Lourenço, S., S119

de Boer, S. H., S70

de Boer, W. J., 134, 1128

de Cara, M., S29, S39, S95

de Cock, A. W., S150, S153

de Faria, R. S., S21

de Figueiredo, P., S7

de Franqueville, H., 300

de Jonge, R., S64

de la Cerda, K. A., S152

De La Fuente, L., S28, S29, S97

de Sá, P. B., 880, 890

de Silva, A., S98

de Silva, A. S., S78, S96

de Souza, S. R., S111

Deah, K. L., S52

Deahl, K., S161

Deb, D., S158

Dedeurwaerder, G., S26

Dee, M. M., S131

Degaetano, A. T., S26

Degrassi, G., 262

Deising, H. B., 444

Del Castillo, J. M., S29

Del Ponte, E. M., S121

del Rio, L. E., S77, S184, S189

del Río, M., S86

del Rio Mendoza, L. E., S18, S89

Delaney, M. A., S30

Delfosse, P., S32, S76

Delgado, J. A., 290

Delic, D., S81

Delvaux, B., S58

Demangeat, G., 384

Demethylation inhibitor fungicides

for Cercospora arachidicola, resistance to, $\mathrm{S} 105$

for Sclerotinia homoeocarpa, effect on population structure, S197

Dendroctonus ponderosae (mountain pine beetle), on whitebark pine, forest restoration and, S166

Deng, X., 567, S24, S73

Deng, Y., S49

Denny, T., S199

Denny, T. P., S45

Deoxynivalenol

and barley, 33, Cover photo January, S15

in corn for ethanol production, S180

Fusarium asiaticum on barley and, 328

Fusarium graminearum on wheat and of $3 \mathrm{ADON}$ population vs. $15 \mathrm{ADON}$ population, 1007, S4

accumulation of DON during grain development, 763

correlation with disease severity, S186

evaluation of cultivars for resistance, S186 glyphosate and, S193

and late Gibberella zeae infection in winter wheat, 719

resistance of wheat against, S50

in small grain, integrated management strategies for, S137

DeRobertis, C., S28

Derr, J., S28, S205

Desbiez, C., 1373

Desmodium tortuosum (beggarweed), Phakopsora

pachyrhizi on, in Alabama, S29

Detweiler, A. J., S206

Devescovi, G., 262

Devorshak, C., S156

Dewdney, M. M., S85, S86, S130, S174

Dewey, R. L., S37

Dhawan, R., S11

Dhingra, A., S142

Diagnosticians, overview of, S168

Diaphorina citri (Asian citrus psyllid)

and $C a$. Liberibacter spp.

$\mathrm{Ca}$. L. americanus, influence of temperature on acquisition, $\mathrm{S} 11$

Ca. L. asiaticus: in salivary glands and alimentary canal of, S6; spread through retail nurseries and garden centers, S46

detection of, S77

on orange jasmine and citrus trees in Brazil, S74

Diaz Arias, M. M., S30

Dickeya sp.

with GFP, colonization of potato plants by, 134

on Phalaenopsis orchids, S22

on pineapple, S78, S98

on potato, 134,1128

type III secretion system of, S144

Dickinson, M. J., 143

Dicklow, B., S32

Dickman, M., S58, S160

Didymella bryoniae

on cucurbits, boscalid resistance, S201

fungicide resistance in, iron sulphur gene $(\mathrm{DbSDHB})$ and, $\mathrm{S} 9$

sensitivity to DMI and carboxamide fungicides, S126

Difenoconazole, for Colletotrichum coccodes on potato, $\mathrm{S} 93$

Dihydroorotase dehydrogenase, from Phytoph-

thora infestans, S39

DiLeo, M. V., 871, S104

Dillard, H. R., S20

Dill-Macky, R., 80

Dimethomorph, for Phytophthora spp., S90, S195

Ding, Y., S206, S207

Dingus, B., S208

Diodia virginiana, criniviruses on, $\mathrm{S} 128$

Dion, Y., S193

Disease management, challenges and constraints on new strategies for, S95

Disease severity, Horsfall-Barratt scale, for hypothesis testing, 1030

Distillers wet grains, microbial characterization of, S181 
Divo de Sesar, M., S99

DNA barcoding, Pythium spp. and, S153

DNA-2 satellite, Tomato yellow leaf curl virus and, S53

Dobhal, S., S30

Dobinson, K. F., S64

Doddapaneni, H., S30

Dodder (Cuscuta indecora), colonization of by

Ca. L. asiaticus and Ca. L. americanus, 756

Dodds, P., S75

Dodge, S., S136

Dodine

for Cercosporidium personatum on peanut, S200

for Venturia inaequalis on apple, S27

Dogwood. See Cornus florida

Dolezal, W. E., S98, S181

Domier, L. L., S71

Donahoo, R., S52

Donahoo, R. S., S30

Donald, P., S30

Dong, H., 573

Dong, W., S31

Donofrio, N. M., S66, S207

Doraiswamy, V., S54

Dorel, M., S58

Dorrance, A., S185

Dorrance, A. E., S33, S39, S123, S184, S189,

S190, S191, S192

dos Santos, J., S121

Dossey, S., S53

Dothistroma spp.

D. pini, PCR for detection of in pine, 105

D. septosporum on lodgepole pine, climate and, S132 PCR for detection of in pine, 105

Dou, D., S158

Doubledee, M., S31

Douglas fir. See Pseudotsuga menziesii

Douhan, G. W., S152

Doustseddigh, H., S31

Dowell, F., S134

Drake, J., S77

Draper, M. A., S161, S191

Dreaden, T. J., S176

Drechslera tritici-repentis, on wheat in Norway, S36

Drennan, J. L., S147

Driver, J. G., S31

Dror, O., 252, S22

Drought stress, and morphological and physio-

logical alteration of corn root structures, S57

Druffel, K. L., S5, S130

Dry, I. B., 1240

du Toit, L., S53, S142

du Toit, L. J., S169

Duan, J., 805

Duan, Y., S30, S41, S145

Duan, Y. P., 239

Duarte, I., S31

DuBose, V. B., S60

Duffy, B., S54, S59, S120

Duffy, S., S149

Dugan, D., S39

Dumenyo, C. K., S61

Dumonceaux, T., S69

Dung, J. K., S31

Duniway, J. M., 871

Dunkle, R. L., S155

Durand, R., 1352

Dutt, M., S86

Dutta, B., S148, S200

Duveiller, E., 474, S156

Duvivier, M., S26

Duyme, F., 1352

Dyer, A. T., 97, S87

EagleView software, for evaluation of SNPs in Sirococcus clavigignenti-juglandacearum, S17
Eastwell, K., S130

Echeverrigaray, S., 199

Echinacea purpurea, endophytes of, and production of natural products, S44

Eckstein, B., S11

Edge factor, and Candidatus Liberbacter solanacearum on potato, $\mathrm{S} 138$

EDS1 gene, for defense of grapevine against Erysiphe necator, $\mathrm{S} 38$

Edwards, M. C., 1298

Effector proteins

AvrBs3 effectors, Xanthomonas oryzae pv. oryzae and, S159

and broad-spectrum against oomycetes and fungi, S158

of cyst nematodes

mode of action, S179

modulation of plant molecular processes and, S186

and perception in Arabidopsis roots, S108 trafficking of in plant cells, S132

Fungal Secretome Database for identification of, $\mathrm{S} 25$

Egel, D. S., S32

Egestion-Salivation Hypothesis, S9

Eggenberger, A., S187

Eggertson, Q. A., S153

Eghbalian, F., S32

Eichenlaub, R., 252, S22

Eisenback, J. D., S32, S206

Ekramoddoullah, A. K. M., 356

El Jarroudi, M., S32, S76

Elad, Y., 97, 225, 913, S33

Elafifi, S., S33

Elateek, S. Y., S33

Elegbede, C. F., 1262

Elen, O., S36

Elena, S. F., S149

El-Habbak, M., S107, S119

Elicitor proteins, Trichoderma virens SM3 and, biological control and, S27

ELISA kits

for chlorothalonil and iprodione residues on creeping bentgrass, $\mathrm{S} 64$

for Pea enation mosaic virus, S130

for Squash vein yellowing virus on watermelon, $\mathrm{S} 134$

for subspecies of Clavibacter michiganensis, S187

Elkahky, M., S12, S33

Elliot, M. L., S175

Ellis, J., S75

Ellis, M. A., 345, S6

Ellis, M. L., S33, S184

Ellis, S. D., S33

Ellor, T., S164

Elmazaty, M., S33

Elmer, W. H., S195

El-Sheshtawi, M., S33

Elsinö̈ fawcetti, on grapefruit, resistance and, S86

El-Tarabily, K. A., S34

Emaravirus spp., Rose rosette-associated virus and Redbud yellow ringspot-associated virus, S67

Emerging pathogens, diagnostics and, S175

Emery, R., S87

Endophytic bacteria

Bacillus cereus, vs. strains causing foodborne illness, S82

Benlate and, S170

of Echinacea purpurea, and production of natural products, $\mathrm{S} 44$

production of antimicrobial compounds by, S38

Endotoxins, of Bacillus cereus, vs. endophytic strains, S82

Engels, R., S64

English, J. T., 1111, S43
Enis, J. N., 415

Enoyl reductase, of Alternaria alternata, and pathogenicity, 120

Ensley, S. M., S109

Enterobacter cloacae, on onion, pathogenicity determinants of, $\mathrm{S} 53$

Enzenbacher, T. B., S34

EPA

evaluation of antibiotic uses, FIFRA and, S166

overview of, S168

Epidemics, interactions between pattern, process, and scale in, S120

Eradication zone, optimal, and landscape pattern, invading epidemics and, 632

Eremochloa ophiuroides (centipedegrass), Colletotrichum sublineola on, S126

Ermacora, P., 390

Errata

vol. 100(3):225-229, 2010, 400

vol 99(8):951-956, 2009, 204

Erwinia spp

E. amylovora

on apple, 532, S12, S68

HrpL regulon of, $\mathrm{S} 80$

kasugamycin and, S166

molecular signature of differential viru-

lence in natural isolates of, 192

RcsC sensor kinase of, S133

E. tracheiphila

on cucumber, S165

on cucurbits, $\mathrm{S} 112$

on muskmelon, S26, S112, S189

Erysiphe necator

benomyl for, resistance against, $\mathrm{S} 12$

from different Vitis spp. and geographic origins, variation in pathogenicity and aggressiveness, 1185

dynamics of ascospore maturation and discharge in, 1321

on grapevine

density-dependent latency of, S38

EDS1 as component of defense against, $\mathrm{S} 38$

effect of acute low-temperature events on, 1240

environmental conditions and primary

infection in Michigan, S9

new biocontrol strategy for, S19

new fungicides for control of, S136

Quinone outside Inhibitors for, and resistance, S9

Gubler-Thomas grape powdery mildew risk index and, revising high temperature threshold for, S17

honeybee proboscis extension reflex as biological sensor for, S124

seasonal ascospore release by, $\mathrm{S} 88$

Esca-related pathogenic fungi, in grapevine, early events prior to visual symptoms, 424

Escudete lesion on olive, and Botryosphaeriaceae collected from in Spain and California, 1340, Cover photo December

Eskandari, F. M., S34, S206

Esker, P., S67, S185

Esker, P. D., S34, S79, S119, S186, S188

Eskridge, K., S147

Esmenjaud, D., 384

Esquivel, J., S127

Essential oils

for control of Phytophthora capsici, S60

from Monarda spp., for control of Rhizoctonia solani on tomato, 493

Estevez De Jensen, C., S34

Ethylene

Fusarium oxysporum on melon and, 682

and Magnaporthe oryzae on rice, S49, S146 plant immunity and, S160

Eucalyptus spp., Ceratocystis fimbriata on, in 
Brazil, bacterial communities associated with, S35

Eugenia koolauensis, Puccinia psidii on, in Hawaii, protecting from further losses, S128

Eujayl, I. A., S123

Eutypa lata, host range, biological variation, phylogenetic diversity of in California, 1048

Evans, T. A., S66, S207

Eversole, K., S167

Everts, K., S32, S51, S99, S207

Everts, K. L., S146

Exner, C., S184

Exotic plant pathogens, landscape pattern and optimal eradication zone, 632

Expression vectors, Tomato bushy stunt virusbased, S76

Exserohilum sp., on bermudagrass and zoysiagrass in Texas, S57

Extension jobs, overview of, S168, S169

Extracytoplasmic function (ECF) sigma (s)

factors, in Pseudomonas syringae pv. syringae, S12

Eyles, A., 460

F. oxysporum f. sp. gladioli, Agrobacteriummediated transformation of, S67

Fabre, B., 105

$F A D 3$, in soybean, and defense-related physiology, S119

Faghihi, J., S185

Fagus grandifolia, climate change and tree dieback and decline in Maine, S195

Fairy ring, in cranberry, control strategies for, S94

Fajolu, O. L., S131

Fallow period, influence of on soil microbial communities in Bolivian highlands, S41

Fan, J., S61

Fang, X. L., S35

Fang, Z. D., 111

Faris, J. D., S151

Farley, L., S39

Farman, M. L., 890

Farnsworth, J. L., S40

Farrell, J. D., S184

Farrokhi Nejad, R., S113

Faske, J., S16

Faske, T., S16, S35

Fatokun, C. A., S92

Fauquet, C. M., S10, S154

Faust, J. E., S128

Fazekas, M., S51

Fei, S., S184

Feliciano-Rivera, M., S35

Felise, H. B., S160

Fellers, J., S151

Feng, C., S35, S53, S72, S139, S145

Feng, J., 328

Fern, leatherleaf. See Rumohra adiantiformis

Fern distortion syndrome

endophytic bacteria, Benlate and, S170

fluorescent pseudomonads and, S63

Fernández-Muñoz, R., 582

Fernandez-Ortuno, D., S35

Fernández-Pavía, S., 1176

Ferrandino, F., 1030

Ferreira, A., S35, S77

Ferreira, J. J., 1315

Fertilizers, for blueberry and grapes, phosphoric acid generation and, S16

Fessehaie, A., S36, S80

Festuca arundinacea (tall fescue), Rhizoctonia solani on, S80, S205

Fetters, T., S208

Ficke, A., S36

Ficus benjamina (weeping fig), crown gall in commercial propagation of, $\mathrm{S} 127$

FIFRA, evaluation of antibiotic uses by EPA and S166

Fig. See Ficus spp.
Figeys, D., 848

Figueiredo, J., S36

Figueroa Betts, M., S160

Fijivirus sp., in rice, in China, S146

Filho, A. B., S87

Fillippeli, E., S201

Fique. See Furcraea spp.

Fir, Douglas. See Pseudotsuga menziesii

Fischer, K., S10, S154

Fischer, K. F., S154

Fish emulsion (FE), on potato, for scab suppression and tuber yield, S1

Fisher, J., S39

Fisher, T. W., S88

Fitzpatrick, B. M., S45

Fjellstrom, R., S202

Flavonoids, Grapevine leafroll-associated virus-3 in grape and, S45

Fleites, L. A., S111

Fletcher, J., S18, S59, S110, S155

FlgB mutation, in Xanthomonas axonopodis pv. glycines, on soybean, reduced disease and, S8

Flor, N. C., S36

Flores, F., S7, S36

Florida torreya. See Torreya taxifolia

Floyd, C. M., S66

Fludioxonil

for Penicillium digitatum, 738

for Penicillium expansum, S2, S93

Fluensulfone, for root knot nematodes on tobacco, S28

Fluopicolide, for Phytophthora capsici on peppers and cucurbits, baseline sensitivity, S201

Fluopyram

for control of Plasmopara viticola and Erysiphe necator on grape, S136 for cylindrocladium black rot of peanut, S100 Luna fungicides and, S37

Flutriafol, for Phymatotrichopsis omnivora on cotton, S54

Foliage trimming, for management of Sclerotinia sclerotiorum on carrot, S100

Folimonova, S. Y., 949

Fontaine, F., 424

Food and Agriculture Defense Initiative, National

Plant Diagnostic Network and, S177

Food security

climate change and, S179

overview of, S156

threats to agriculture in north central U.S. S181

Foote, P., S123

Forbes, G., S121, S156

Forest ecosystem restoration, S166

Forkhead-box protein, in Magnaporthe oryzae, S97

Formento, N., 58

Forouhar, F., S77

Forster, H., S2, S163, S166

Förster, H., 738

Fortnum, B. A., S100

Fortunato, A. A., S96

Fortunella spp. (kumquat), Xanthomonas anxonopodis pv. citri on, S24

Forum, for Bremia lactucae on lettuce, rainfastness of, S66

Foster, B., S162

Fought, L., S37

Fountain, J. C., S37

Fourrier, C., 105

14-3-3 protein, of tomato, and immunityassociated programmed cell death, $\mathrm{S} 92$

Fox, G. M., S196

Fraaije, B. A., S12, S35, S49, S51

Fraaije, M. W., S12

Fraedrich, S. W., 1118

Fragaria spp. (strawberry)

$F$. $x$ ananassa

Botrytis cinerea on, S6
Colletotrichum spp. on, S21, S75, S83, S106

fungal and oomycete pathogens of in Western Australia, S35

Podosphaera aphanis on, 246, S8

Xanthomonas fragariae on, S64, S83

Botrytis cinerea on, $\mathrm{S} 134$

F. chiloensis (Chilean native strawberry), Strawberry mild yellow edge virus in ecotypes of, S110

disease management in Philippines, S130

Podosphaera aphanis on, S194

Rhizoctonia fragariae and black vine weevil on, S195

Verticillium dahliae on, S193

Xanthomonas fragariae on, S174

Fragoso, R. B., S111

Francis, D. M., S20

Francis, M. I., S37

Franco, B., S87

Franco, S., S13

Franco-Lara, L., S176

Frank, M., S37

Frankliniella spp.

feeding behavior of, and Tomato spotted wilt virus infection, $\mathrm{S} 122$

as vector for Iris yellow spot virus, $\mathrm{S} 122$

Frantz, G., S134

Frantz, J., S144

Frantz, J. M., S74

Frare, G. F., S74

Fraxinus nigra, climate change and tree dieback and decline in Maine, S195

Frederick, R. D., S37, S61

Freeman, S., 1176

Freeman, T. P., 279

Frei, U., S184

French, R., 230, S125, S149

French-Monar, R. D., S173

Frenkel, O., 1185

Frey, J. E., S120

Frey, P., 105

Friesen, T., S151

Friesen, T. L., 1298, S144, S151

Fry, J., S91

Fry, W., S77

Fry, W. E., S20, S26, S52

Fsr1-interacting proteins, Fusarium verticillioides virulence and, S62

FST1 gene, of Fusarium verticillioides, functional characterization, S62

Fu, Y., S145

Fuchs, M., 384, S93

Fudal, I., S158

Fukuda, S. K., S82

Fukumoto, T., 85, 120

Fulbright, D. W., 337

Fulton, J., S86

Fumonisin, and Fusarium verticillioides on maize, S147

Fungal Expression Database (FEDB), overview of, S97

Fungal Genetics Stock Center, overview of, S80

Fungal Secretome Database, for identification of effector proteins in plant pathogenic fungi, S25

Fungi, sequence-based identification of, promise and pitfalls of, 732

Fungicides

adjuvant, performance assessment and, S142

for Alternaria alternata, resistance against, S14, S130

ametoctradin, oomycete-specific, S63

azoxystrobin, for Rhizoctonia solani on sugar beet, $\mathrm{S} 102$

benlate, fern distortion syndrome and, S170

benomyl, for Erysiphe necator, resistance against, $\mathrm{S} 12$

benzimidazole for Botrytis cinerea on rose, S62 
for Venturia inaequalis on apple, S189

for blueberry and grapes, phosphoric acid generation and, S16

boscalid

for Botrytis cinerea on apple, S63, S143

for Didymella bryoniae, S9, S201

for Penicillium expansum on apple, S63

for Botrytis cinerea

stability and fitness of resistant phenotypes, S63

on strawberry, S6

for brown rot on peach, S195

carboxylic acid amide, 522

for Cercospora arachidicola, resistance to, $\mathrm{S} 105$

for Cercospora sojina on soybean, S145

for Cercospora zeae-maydis on corn, $\mathrm{S} 202$

for Colletotrichum acutatum on citrus, S118

for Colletotrichum graminicola, on maize, S19

for Colletotrichum orbiculare on cantaloupe, organically certifiable, S35

for control of tomato disease, Tom-Cast and, S147

on corn, at-tassel application of, S5

for crown rust on oats, yield response, S46

demethylation inhibitor, for Sclerotinia

homoeocarpa, S197

for Didymella bryoniae, and resistance, S126

Difenoconazole, for Colletotrichum coccodes on potato, $\mathrm{S} 93$

effect of timing on yield and grain fill, aphid pressure and, S182

effect on hail-damaged corn, S34

for Erysiphe necator, resistance against, S9

for Erysiphe necator on grape, S136

Fludioxonil, for Penicillium expansum on apple, S93

for Fusarium graminearum, in Brazil, S121

for Fusarium oxysporum f. sp. niveum on watermelon, S32

Heritage 50 WDG for control of Alternaria tagetica on marigold, S46

iprovalicarb, for Phytophthora capsici, 1162 S74

IR-4 project and registration update, S126

kasugamycin, overview of, S166

Luna fungicides, S37

for managing downy mildew on cucurbits, quantitative review, 1066

metalaxyl, for Pythium ultimum, S102

model to predict selection for resistance, S51

modeling activity of on Septoria leaf blotch of wheat, S63

mutations in succinate-dehydrogenase inhibitor target protein and, resistance and, S37

novel timings for turfgrass diseases in upper Midwest, S64

Orvego, for Peronospora and Pseudoperonospora control in ornamentals, S60

oxidized silver as, $\mathrm{S} 48$

for Penicillium expansum, management of resistance, $\mathrm{S} 163$

against Penicillium expansum, reduced sensitivity to, $\mathrm{S} 2$

for Penicillium expansum on apple, S63

penthiopyrad, for Ascochyta rabiei on chickpea, S125

for Peronospora belbahrii on basil, S107

for Peronospora sp. on sweet basil, S175

for Phakopsora pachyrhizi on soybean, S203

for Phoma terrestris on onion, S113

for Phytophthora capsici on cucurbits, S195

for Phytophthora erythroseptica on potato, inheritance of resistance, $\mathrm{S} 183$

for Phytophthora spp., S90

for Plasmodiophora brassicae on canola, S99

for Plasmopara viticola on grape, S136

for Podosphaera xanthii, S16, S79

postharvest, resistance mechanisms in, S162 and postharvest decays of pome fruits, management of resistance, $\mathrm{S} 163$

and PROCULTURE model, for septoria wheat

leaf blotch on winter wheat, S32

propiconazole

and Ceratocystis fagacearum on red oaks, 979

for Sclerotinia homoeocarpa on turfgrass, S102

for Puccinia arachidis on peanut in Nicaragua, S8

for Puccinia graminis f. sp. tritici on wheat, $\mathrm{S} 44$

for Puccinia kuehnii on sugarcane, S175

for Pythium aphanidermatum on bean, S48

QoI inhibitors

Alternaria solani on tomato, in North Carolina, S55

for Venturia inaequalis, S69

Regalia, for control of cucumber powdery mildew and lettuce downy mildew, synergistic effect with other fungicides, S123

Revus and Forum, for Bremia lactucae on lettuce, rainfastness of, S66

for Rhizoctonia solani on sugar beet in Nebraska, S48

for Rhynchosporium secalis on barley, resistance against, S49

for Sclerotinia homoeocarpa, early-season programs for, $\mathrm{S} 137$

for Sclerotium rolfsii on peanut, S40, S199

single-site and multi-site, mixtures of, S51

on soybean, effect on yield and yield components, S14, S50

succinate-dehydrogenase inhibiting, S9, S12

tebuconazole

adaptation of Fusarium graminearum to, 436

for Cercospora arachidicola on peanut, S105

triazole-based, $F$. graminearum on wheat, 160 for Venturia inaequalis on apple, S23, S100

for Xanthomonas fragariae on strawberry, S83 Zampro, S57, S131

Fungus gnats. See Bradysia impatiens

Funnell-Harris, D. L., S37, S185

Furcraea spp. (fique), Olpidium virulentus on, in

Colombia, S42

Furman, B. J., S109

Fusaric acid, from Fusarium proliferatum on garlic, S95

Fusarium spp.

F. acuminatum, on bean, $\mathrm{S} 185$

F. aestuarinus, on smooth cordgrass, S195

F. asiaticum, population genetic analysis of in

China, 328

F. avenaceum

on pea roots, $\mathrm{S} 42$

on peas in North Dakota, S25

on blueberry in Argentina, S21

Brassica spp. short-cycle cover crops for management of, S190

on corn, at-tassel fungicide application and, S49

crosses from highly aggressive parental iso-

lates, variation and transgression of aggressiveness in, 904

on cucurbits, Ascophyllum nodosum extract and silicon for, $\mathrm{S} 205$

CYP51C gene from, for phylogenetic analysis, $\mathrm{S} 35$

F. graminearum

adaptation of to tebuconazole, 436

$3 \mathrm{ADON}$ and 15ADON isolates from wheat in North Carolina, 1007, S4

on barley: deoxynivalenol and, chloroplast pigments in leaf tissues, 33, Cover photo January; evaluation of multiple management strategies for, S43; glyphosate effect on DON content and inoculum production, S193; modeling response to field temperature and wetness duration, S15

BDM1 and virulence of, S52

characterization of kinome of, S151

on corn, Fusarium toxins in, and ethanol production, $\mathrm{S} 180$

fungicide management programs for in Brazil, S121

lack of specialization of, 1057

on pea roots, gene expression patterns of, S42

pyraclostrobin resistance in, S147

on soybean, identifying resistant genotypes, S33

triazole-based fungicides for, 160

trichothecene mycotoxins associated with, 290

on wheat: aggressiveness of chemotypes with different levels of disease resistance, S189; collection of isolates 40-300 meters above ground, S208; correlation between disease severity and deoxynivalenol, S186; deoxynivalenol and nivalenol accumulation in, 763; epidemics in Nebraska, 2007 and 2008, S191; evaluation of cultivars for resistance, S50, S186; glyphosate effect on DON content and inoculum production, S193; grain yield, cultivar resistance and, S113; in Ohio, El Niño-Southern Oscillation and atmospheric teleconnection patterns, S66; single-kernel nearinfrared technology to sort kernels based on scab and deoxynivalenol levels, S134; spatial heterogeneity in disease incidence, S65; validation and haplotyping of resistance genes in diverse germplasm, S104

$F$. lateritium, on Florida torreya, S174

$F$. mexicanum, and mango malformation

disease, 1176, Cover photo November

$F$. moniliforme, on maize, $\mathrm{S} 4$

F. oxysporum

on banana, biological control of, S146

biological control of, synergistic effect between strains, S13

on carnation, soil biodisinfection for control of, S39

on chickpea, genetic diversity of, in Iran, S46

on cotton, S21, S200

on cucumber, in hydroponic systems, S95

on cucurbits, extracts from Ascophyllum nodosum for, S18

exploring lineage-specific chromosomes of, S75

on koa, in Hawaii, S118

on melon and hormone disruption, 682

on Physalis peruviana, S129

race 3, on tomato in Iran, $\mathrm{S} 101$

on strawberry, in Western Australia, S35

on tomato: detection of in Mexico using soil phytopathometry, S29; effect of fumigation, mustard meal amendments, and grafting on, S73; grafting as disease management tool for, S135; silicon for control of, S52

on watermelon: management with fungicides, S32; resistance of triploid cultivars, S99; Streptomyces lydicus and cover crop for management of, S51; Vicia villosa cover crop for suppression of, S207

population genetic framework for understanding aggressiveness of, S157

$F$. proliferatum, on garlic, fusaric acid production and, S95 
F. pseudograminearum, lack of specialization of, 1057

F. redolens, on bean, $\mathrm{S} 185$

relationship between yearly fluctuations in intensity and environmental variables, 784

in small grain, integrated management strategies for, $\mathrm{S} 137$

F. solani

Bacillus subtilis M36 for control of, S84 on cucurbits, S18

non-host resistance response at nucleosome level, S45

on sorghum, lignin biosynthesis and, 671, S37

on soybean

characterization of on scale of individual seeds/roots, S111

lignin levels and, 671, S37, S185

multilocus genotyping for species diversity, 58

soybean cyst nematode infestation and resistance, S29

on sugarbeet in Iran, PCR-RFLP analysis on, S13

F. thapsinum, on sorghum, $\mathrm{S} 90$

on tomato, effect of fumigation, mustard meal

amendments, and grafting on, S73

F. tricinctum, on soybean, $\mathrm{S} 188$

$F$. verticillioides

antagonistic response to, $\mathrm{S} 10$

CBF transcription factor family in, $\mathrm{S} 109$

conidiation of, genes differentially expressed during, S18

on corn: characterization of genes regulating colonization, S148; FB1 translocation in seedlings infected with, S147; FvNoxR gene of, S44; in Nigeria, S117; nitric oxide detoxifying flavhemoglobin and, S10

Fsr1-interacting proteins and virulence, S62

FST1 gene of, functional characterization, S62

MADS-box family of transcription factors in, S94

metabolic fingerprinting technique for functional genomics in, S120

polyketide biosynthetic gene clusters in, S18

F. virguliforme

in soil, quantification of using SYBR green and Taqman assays, S80

on soybean: extraction from crop residue and conidia, S187; field and greenhouse evaluation of fungicide seed treatment for control of, S191; foliar symptoms and early infection of, S144; Phialophora gregata and, S79; and Phialophora gregata co-inoculation, S188; plant antFvTox 1 antibodies against, S183

for virus-induced gene silencing studies, S187

on wheat

integrated management of, S87

monitoring using quantitative real-time PCR, 49

plant height and severity of crown rot, 1276

resistance against, cytochrome p450 gene and, 183, Cover photo February

Futai, K., 1289

FvTox1 antibodies, and Fusarium virguliforme on soybean, S183

Gabriel, D., S108, S111

Gadoury, D. M., 246, 1240, S8, S38, S88

Gaeumannomyces graminis var. tritici

periodicity in host availability and evolutionary branching, 1169

and take-all disease, Phialophora spp. and, 404 on wheat, Pseudomonas spp. for biological control of, S141

Galagan, J., S64, S75

Galbraith, D. W., S154

Gale, L. R., S75

Gallegly, M., S207

Gal-On, A., 225, 798

Galvez, L. C., S38

Gamalero, E., 805

Gamba, F., S118

Gambhir, A., S185

Gamliel, A., 367

Ganiger, M. C., S96

Gao, B., S38

Gao, F., S38

Gao, Q., S38, S139

Garavito, M. F., S39

Garbelotto, M., S115, S167

Garber, N., S39

Garber, R. H., S153

Garces, F., S39

Garcia, A., S107

García, A., S39

Garcia, L., S39

García, M., S95

García-Cano, E., 582

Garcia-Pedrajas, M. D., 1364, S64, S98

Garczynski, S. F., S88

Gardiner, D., S75

Garg, A., S11

Garlic. See Allium sativum

Garneni, S., S133

Garner, J., S16

Garrett, K., S121

Garrett, K. A., S41, S120

Garrett, W. M., 42

Garrido, P., S30

Gartemann, K., S22

Gartemann, K.-H., 252

Garzon, C., S7, S30

Garzon, C. D., S7, S154

Gaska, J., S67

Gaskins, V., S58

Gaskins, V. L., 42

Gasparoto, M., S11

Gassmann, W., S38

Gavin, J. C., S135

Gay, A. P., 21

Gazaway, W. S., S153

Gbur, E. E., S153

Ge, X., S39

Gearhart, K., S39

Gebhart, G. D., S190

Geiser, D. M., 732

Gelbart, D. Guenoune-, 798

Geminiviruses, evolution of, S149

Geneva City School District, New York State

Agricultural Experiment Station partnership and, S20

Genomics of plant-associated microbes, overview of, S167

Gent, D. H., S40, S84, S138

George, S., S122

Geosmithia morbida, on walnut, status in

California, S48

Geotrichum candidum

on peaches and nectarines, S141 on tomato, S33

Geranium, Puccinia pelargonii-zonalis on, S31, S116

Gergerich, R., S67

Gergerich, R. C., S201

Gerik, J. S., S135

Germán, S. E., 376

Gevens, A. J., 941, S40, S174

GFLV. See Grapevine fanleaf virus $G$

GFP (green fluorescent protein)

Dickeya sp. tagged with, 134, 1128

in Ophiosphaerella herpotricha on bermuda- grass, 415

Ghabrial, S., S60, S119

Ghabrial, S. A., 880, 890, S107

Ghadamyari, S., S87

Ghimire, S., S40, S51

Giampan, J. S., S87

Gibberella zeae

crosses from highly aggressive parental isolates, 904

and deoxynivalenol in kernels, 719

influence of mating pheromones and affinityselected peptides on, S43

Gibberellic acid, for management of Botrytis

cinerea on grape, $\mathrm{S} 49$

Giesler, L. J., S185

Gilbertson, R. L., S12, S138

Gilchrist, E., S40

Gildow, F., S100

Gildow, F. E., S126

Giles, C. G., S203

Gill, J. J., S31

Gillespie, J., 290

Gilligan, C. A., 638, 1169

Ginger, Ralstonia solanacearum on, S141

Giraud, F., S32, S76

GIS and GPS, for spatial and temporal analysis

for epicenters of soybean rust disease foci, S186

Gisi, U., S162

Gitaitis, R. D., S9, S122

Gladiolus spp.

Cucumber mosaic virus in, S59

F. oxysporum f. sp. gladioli on, $\mathrm{S} 67$

Glaettli, A., S37

Glandorf, D. C. M., 404

Glass, K. M., S21

Glassy-winged sharpshooters, saliva of, as vector for Xylella fastidiosa inoculation, S9

Gleason, M. L., 345, S15, S26, S54, S112, S189

Glenn, A. E., S10, S18, S147

Gliocladium catenulatum, for Plasmodiophora

brassicae on canola, S99

Gliocladium virens. See also Trichoderma virens, for Sclerotinia spp. on lettuce, S91

Gloeocercospora sorghi, on sorghum grown for bioenergy in Alabama, S16

Glomus intraradices, and hormone production caused by Fusarium oxysporum on melon plants, 682

Glover, K. D., S59

Glover, R., S154

GLRaV-2. See Grapevine leafroll-associated virus 2

GLS. See Gray leaf spot

Glucksman, S., S40

Glyceollin, response of soybean pathogens to, 897

Glycine max (soybean)

Bean pod mottle virus in, S123, S183

Cercospora spp. on C. kikuchii, $\mathrm{S} 22, \mathrm{~S} 26$ C. sojina, $\mathrm{S} 28, \mathrm{~S} 145, \mathrm{~S} 182$

characterization of fungal communities associated with roots, S14

disease survey of commercial fields in Alabama 2009, S118

effect of seed treatment on root diseases and yields of, S89

effect of timing of fungicide application on yield and grain fill, aphid pressure and, S182

$F A D 3$ in, and defense-related physiology, S119

fungicides on, effect of on yield in 2008, 2009, $\mathrm{S} 14$

Fusarium spp. on

characterization of on scale of individual seeds/roots, S111

F. graminearum, identifying resistant genotypes, $\mathrm{S} 33$

lignin levels and, 671, S37, S185

soybean cyst nematode infestation and 
resistance, $\mathrm{S} 29$

F. tricinctum, in Minnesota, S188

F. virguliforme: co-inoculation with

Phialophora gregata and, S79, S188

extraction from crop residue and conidia

S187; field and greenhouse evaluation of

fungicide seed treatment for control of,

S191; foliar symptoms and early infec-

tion of, S144; plant ant-FvTox1 antibodies against, S183

glyceollin and, response of pathogens of to, 897

green stem malady in, S115

Heterodera glycines on, Rhg genes for resistance against, $\mathrm{S} 26, \mathrm{~S} 58$

identification of seedling pathogens from fields planted at three different temperatures, S129

Macrophomina phaseolina on, effect of environment and cultivar on, S31

Phakopsora pachyrhizi on

combinatorially selected peptides for protection against, 1111

effect of solar radiation on disease severity, S143

gene expression during appressorium formation by, S37

influence of environmental conditions on epidemic development, in Nigeria, S128

in Minnesota, five years of monitoring, S66

in Nigeria, virulence and genetic diversity, S190

protein profile differences between resistant and susceptible strains, S96

proteomics for identification of markers for resistance, $\mathrm{S} 164$

Rpp2 locus and resistance, $\mathrm{S} 96$

screening for resistant lines, S61

screening protocol for assessing baseline sensitivity to fungicides, S203

sentinel plots in Florida, S178, S204

transcriptome analysis of interactions, S127

Phialophora gregata on, S79, S186, S188

Phomopsis longicolla on, S26, S70, S148

Phytophthora sojae on

calmodulin gene and resistance, $\mathrm{S} 107$

genes conferring partial resistance, S190

genetic variation in populations from Ohio and South Dakota, S191

mapping multiple novel resistance genes against, S192

modified method to screen for partial resistance, $\mathrm{S} 123$

multiplexed, probe-based quantitative PCR assay for, $\mathrm{S} 48$

Rps 8 gene and resistance, $\mathrm{S} 189$

Pythium spp. on, S33, S111, S184

saccharine and induction of systemic acquired resistance in, $\mathrm{S} 122$

seed treatments for control of seedling diseases, S203

soybean cyst nematodes on, S187, S188, S190

Soybean mosaic virus in, 931

spatial and temporal analysis for epicenters of disease foci, S186

strobilurin fungicides and other pesticides, S50 sudden death syndrome of, 58

survey of diseases of in Ohio River Valley region in 2009, S39

viruses infecting, in Nigeria, S126

Xanthomonas axonopodis pv. glycines on, S8, $\mathrm{S} 103$

Glynn, E., S17

Glynn, J. M., S41

Glynn, N., S106

Glynn, N. C., S173, S175

Glyphosate, DON content and Fusarium graminearum inoculum production in wheat and barley, S193

Gmitter, F. G., S61

Gnats, fungus. See Bradysia impatiens

Goates, B. J., 655, S41

Gobena, D. J., S41

Goenaga, R. J., S176

Goes, da Silva, F., 1089

Goesmann, A., S120

Goh, J., S41

Goheen, D. J., S167

Goheen, E. M., S166

Gold, S. E., 1364, S64, S98

Golino, D., S3

Golino, D. A., 830

Golovinomyces cichoracearum, on sunn hemp, $\mathrm{S} 174$

Gomez, A., S75

Gomez, L., S41

Gomi, K., 85, 120

Gonçalves, F. P., S41

Gongora, C., S188

Gonzáles, E. R., S35

Gonzales, M. A., S41

Gonzalez, A. D., S4

Gonzalez, C., S42

Gonzalez, C. F., S31

González, N., 1340

González, V., 58

González-Vera, A. D., 172

Goodin, M., S11

Goodwin, S. B., S25, S45

Goss, E. M., S42, S157

Gossen, B. D., S59, S99, S117, S125

Gossypium spp. (cotton)

Fusarium oxysporum on, S21, S200

impact of cropping sequence on, peanut, corn and, S20

Meloidogyne incognita on, S75, S202

Phymatotrichopsis omnivora on, S54

Pythium spp. on, S153

Rotylenchulus reniformis on, $\mathrm{S} 86$

Thielaviopsis basicola on, S75

Verticillium dahliae on, S75, S140

Goswami, R. S., S25, S42, S185

Gottwald, T., S172, S200

Gottwald, T. R., 638, 1030, S15

Gougherty, A., S42

Gourley, J., S70

Govindarajulu, A., S42

Gowda, S., S56

Graber, E. R., 913

Grafting, tomato and

Clavibacter michiganensis transmission during, S13

effects of on plants and associated microbial communities, S20

as management tool

for Fusarium spp., S73, S135

for Pythium spp., S73

for Ralstonia solanacearum, $\mathrm{S} 109$

Graham, J. H., S13, S15, S37, S42, S57, S172, S173

Graham, M., S96

Graham, T. L., S20

Gramacho, K. P., S42

Graminella nigrifrons (black-faced leafhopper),

transmission of Maize fine streak virus by, 1138

Granke, L., S43

Granke, L. L., S43

Grape. See Vitis vinifera

Grapefruit. See Citrus paradisi

Grapevine fanleaf virus (GFLV)

high-throughput testing of transgenic resistance constructs from, $\mathrm{S} 93$

in Xiphinema index, transmission competency of single lines, 384

Grapevine leafroll viruses

Grapevine leafroll-associated virus 2, 698,
Cover photo July

Grapevine leafroll-associated virus 3, S3, S45, S56

mealybug transmission of, 830

in Virginia vineyards, $\mathrm{S} 90$

Grapevine necrotic union (GNU), as new disease in California, S3

Grapevine rupestris stem pitting-associated virus (GRSPaV), subcellular location of replicase proteins of, $\mathrm{S} 104$

Grapevine virus $A$, on grapevine in Washington, genetically diverse isolates, $\mathrm{S} 81$

Grau, C. R., S186

Grava, A., 97

Gray, M. E., S3, S74

Gray, S., S61, S100

Gray leaf spot (GLS), in maize, mapping quantitative trait loci for, 72

Graybosch, R. A., 230

Green, J., S11

Green, J. F., 493

Green stem malady, in soybean, S115

Greenberg, J. T., S160

Greene, S. E., 493

Greer, C. A., 502

Grégoire, C., S196

Gremmeniella abietina, nomenclature of, S194

Greve, C., S9

Grimes, J., S39

Grisham, M. P., S43

Groom, J., S60

Gross, D., S76

Gross, D. C., S136

Gross, J., S54

Gross, N. W., S43

Gross, P. L., S43

Grosser, J. W., S37, S86

Groth, D., S65

Groth, D. E., S201

Groundnut ringspot virus (GRSV), on tomato, in Florida, S134

Grove, G. G., S40, S73, S138

Groves, R., S19, S119

Grubisha, L. C., S39, S43

Grunwald, N. J., S42, S150, S156

Grünwald, N. J., 732

Grybauskas, A., S137

Gu, B., S158

Gu, G., S44

Gualandi, R. J., S2, S44

Guaragna, M., S59

Guardado, A., S86

Gubler, W. D., 1048, S17, S124, S129

Gubler-Thomas grape powdery mildew risk index, revising high temperature threshold for, S17

Gudmestad, N., S182, S203

Gudmestad, N. C., S135, S183

Guerra, D. S., S121

Gugino, B., S77

Gugino, B. K., S195

Gulati-Sakhuja, A., S44

Guo, A., 573

Guo, B., S37, S57

Guo, J., S140, S141, S146

Guo, L., 997, S44

Guo, Q., S70, S75

Guo, Y., S3, S44, S105

Gupta, V., S44

Gurung, S., S3, S45, S76

Gustus, C., 80

Gutha, L. R., S45

Gutierrez-Aguirre, I., S81

Guttman, D. S., 208

Guzman-Barney, M., S176

Gwinn, K. D., 493, S2, S44, S131

Gymnoascus reessii, against root-knot nematode, S105

GyrB gene, Xylella fastidiosa and, S115, S116 
$H$ gene, and resistance to Hessian fly, 279

Ha, B., S61

Ha, Y., S45

Hadwiger, L., S45

Hadziabdic, D., S45

Hagan, A. K., S16, S20, S46

Haghighi, S., S46

Hajimorad, M. R., S135

Hajmansoor, S., S6, S32, S62

Halbert, S. E., S46, S77, S107

Halbrendt, N. O., 539, S46

Halkett, F., 1262

Hall, D. G., S6

Halterman, D., S19, S23, S46

Halterman, D. A., 454

Ham, J., S47

Hamilton, J., S153

Hamilton, J. P., S127

Hamilton, S. L., 493

Hammerschmidt, R., S181

Hammond, J., S10, S71, S154

Hammond, R. W., S149, S207

Han, A., S76

Han, P., S47

Han, S., S96, S158

Hancock, J. F., S83

Hand, E. K., S17

Hanke, D. E., S70

Hanna, L., S111

Hansen, J., S3

Hansen, M., S135

Hanson, L. E., S47

Hanson, S., S47, S62, S68, S107

Hao, J., S60, S72, S74, S82

Hao, J. J., 1162

Hao, L., S47

Hao, W., S47, S51

Harbertson, J. F., S45

Harding, M. W., S48

Harding, R., 271

Harel, Y. M., 913

Hari, K., S59

Harman, G., S165

Harman, G. E., 1213

Harmon, C. L., 941, S177

Harmon, P. F., 941, S36, S130, S138, S152, S175, S201

Harnsomburana, J., S1 1

Harper, S. J., 1282

Harrington, T. C., 345, 1118

Harris, D. K., S61

Harris, M. O., 279

Harrison, L., S48, S207

Harrison, N. A., S69, S175

Harrison, S., 511

Harrison, S. A., 484

Hartman, G., S190

Hartman, G. L., 897, S48, S107, S128, S131, S185

Hartman, J. R., 345, S6

Hartung, J., S143

Hartung, J. S., 756, 1077, S42, S111, S143

Harveson, R. M., S48

Hasey, J. K., S48

Hatfield, J. L., S179

Hau, B., S82

Haudenshield, J., S190

Haudenshield, J. S., S48, S107, S131, S185

Hauff, R., S128

Hausbeck, M., S43, S133, S176

Hausbeck, M. K., 619, S34, S43, S201

Havens, W. M., 880, 890

Hawkins, N., S49

Hayes, R. J., 1222, S107

Hazanovsky, M., 271

He, B., S135

He, G., S105

He, M., 593

He, Y., S185
He, Z., S49, S92

He, Z. H., 313

Hearne, S., S113

Heaton, E., S180

Hed, B., S49

Hedley, P. E., S80

Heidenreich, M. C., 246

Heiman, D., S64

Hein, G. L., 230

Helianthus spp. (sunflower)

Macrophomina phaseolina on, S128

in Nebraska, survey for predominant diseases of, S48

Helicobasidium sp., on cranberry, and fairy ring, S94

Helix aspersa (brown garden snail) attraction of Caenorhabditis elegans to, S27 nematode and bacterial associates of, S113

Helliwell, E. E., S49

Helminthosporium victoriae, broad-spectrum antifungal protein from, 880,890

Henderson, D. C., S10, S154

Henn, A., S5, S49

Henne, D. C., S50, S138, S203

Henrissat, B., S64

Henry, G., S158

Henry, R., S50

Herbaspirillumn seropedicae, for control of Ustilago scitaminea, $\mathrm{S} 111$

Herbicolins. See also Pantocin A, of Pantoea vagans $\mathrm{C} 9-1$, S59

Herman, M., S41

Hernandez, F. R., S4

Hernandez, M. G., S89

Hernandez Nopsa, J., S50, S147, S186, S191

Hernandez-Martinez, R., S87, S101

Hernandez-Zepeda, C., S50

Herrero, M. L., 246

Herrero, S., S121

Hershman, D., S137

Hershman, D. E., 160

Hert, A., S66

Heterodera spp. (cyst nematodes)

$H$. avenae and $H$. filipjevi, PCR for distinguishing, 216

CLE perception in Arabidopsis roots, S108

effector proteins of, modulation of plant molecular processes, $\mathrm{S} 186$

H. glycines (soybean cyst nematode)

on Arabidopsis thaliana, characterization of bHLH transcription factors induced in, S187

on bean, $\mathrm{S} 102$

effect of poultry litter on reproduction of, S29

extension demonstration and outreach for management of, S185

secreted CLE proteins of in plant cells, S132

on soybean: BPMV and SMV vector systems to explore interactions, S187; effect of planting density, population size, and soil $\mathrm{pH}$ on, S188; Fusarium spp. and, S29; resistance of varieties in fields infested with different HG types, S190; Rhg genes for resistance against, S26, S58

on sugar beet root, $\mathrm{S} 111$

uptake and exclusion of proteins by, S38

H. schachtii

Dactylella oviparasitica from soils suppressing growth of, S141 on sugar beet, S108, S136

Heterokaryon incompatibility, in Aspergillus

flavus and Aspergillus parasiticus, $\mathrm{S} 85$

Hettwer, U., 444

Heungens, K., S42

Hewezi, T., S132, S179, S186, S187

HG test, for soybean cyst nematode resistance,
S190

Hickman, L. L., S28

Higbee, B., S119

Higgins, B., S122

High Altitude Balloon Experiments in Technology (HABET) program, overview of, S188

Highland, H., S50

Highland, H. B., S200

High-throughput sequencing, viruses and, S154

Higuchi, K., S143

Hijmans, R., S121, S156

Hilf, M. E., S70

Hill, C. B., 897

Hill, J., S120, S187

Hill, J. H., S96

Hillman, B., S98

Hily, J., S50

Himmelstein, J., S51, S207

Hingston, L. H., 460

Hinton, D. M., S10

Hirayae, K., 612

Hirsch, R. L., S148

Hladky, L., S128

Hobbelen, P. H., S51

Hodges, T., S154

Hoeschele, I., S190

Hoffmann, L., S32, S76

Hogenhout, S. A., 1138, S27, S184

Hogetsu, T., 747

Hogg, A. C., 97

Hoitink, H., S124

Hoke, S., S32

Holah, N., S181

Holah, N. S., S186

Holb, I. J., S51

Holbrook, C. C., S105

Holdengreber, V., 798

Holland, J. B., 72

Holland, R., S26, S31

Hollier, C. A., S201

Holmes, G. J., 1066

Honeybee, proboscis extension reflex as biological sensor for Erysiphe necator, S124

Honeycutt, C., S92

Honeycutt, W., S67

Hong, C., 632, S47, S51, S97, S207

Hooftman, R., S81

Hoogenboom, G., S92

Hooks, C. R., S133

Hop, Podosphaera macularis on, S40, S138

Hopkins, D., S52, S201

Hordeum vulgare (barley)

Blumeria graminis on, 21, S158

Cochliobolus sativus on, S110, S118

deoxynivalenol and, 33, Cover photo January

Fusarium asiaticum on, 328

Fusarium graminearum on, S15, S43, S193

Puccinia graminis on, S157

Puccinia hordei on, S4

and PWT1 avirulence allele of Magnaporthe oryzae, 436

Pyrenophora teres on, S68

septoria speckled leaf blotch and net form net blotch of, 80

Horevaj, P., S52

Hormesis, cyazofamid, Pythium aphanidermatum and, S36

Horn, B. W., S85, S92, S157

Horseradish, bacterial species associated with internally-discolored roots, S191

Horsfall-Barratt scale, for hypothesis testing, consequences of use of, 1030

Horsman, L., S134

Horton, T. R., S29

Horvath, B., S6, S205

Horvath, B. J., S28, S80, S152

Hoshi, A., S52

Hosogi, N., 840

Hosseini, P., S127 
Host availability. See Periodicity in host availability

Host-selective toxins, Pyrenophora tritici-repentis on wheat and, 474, S160

Houchins, D., S108

Howard, R. J., S48

Howard, S., S38

Howe, P. J., S186

Hoy, C., 1138

Hoy, J. W., S39

Hoy, M. A., S22

Hresko, M., S38

HrpG and HrpX regulons, of Xanthomonas axonopodis pv. citri, S44

HrpL regulon, of Erwinia amylovora, S80

HRT protein, resistance to Turnip crinkle virus, and photoreceptors, S56

Hsu, H., S59

Hsu, S., S71

$\mathrm{Hu}, \mathrm{C} ., \mathrm{S} 52, \mathrm{~S} 68$

Hu, C.-H., 997

$\mathrm{Hu}$, J. S., S82

Hu, X., S61, S133

Huang, C., S52, S53

Huang, G., S116, S141

Huang, J., 822

Huang, X., S53, S74

Huanglongbing. See also Candidatus Liberibacter colonization of Cuscuta indecora and, 756 Cover photo August

current status and future of, S200

early events of at ultrastructural level, 949 . Cover photo September

Huber, D. P., S132

Huber, L., S76

Hudson, M., S106

Hudson, W., S78

Hughes, M. A., S177

Hughes, T., S26

Hughes, T. J., S186

Hulbert, S. H., S142, S167

Hulvey, J., S41

Human pathogens, on plants, S168, S177

Humann, J. L., S53

Humphry, M., S158

Hurburgh, C. R., S109

Hussey, R., S141

Hussey, R. S., S116, S186

Husson, C., 1262

Hutmacher, R. B., S153

Hutton, D., S75

Hwang, J., S150

Hwang, S., S99

Hydrangea spp.

Corynespora cassiicola and Cercospora hydrangeae on, $\mathrm{S} 84$

Pucciniastrum hydrangeae on, evaluation of resistance against, $\mathrm{S} 71$

Hydrogen peroxide

Alternaria alternata in Japanese pear, 840

in barley with Cochliobolus sativus, S118

Hynes, R. H., S99

Hyon, G.-S., 840

Hypersensitive response (HR)

Blumeria graminis interactions with barley, 21

of maize, lesioned mutants for characterization of, S11

Hyperspectral remote sensing, for Sugarcane yellow leaf virus in sugarcane, $\mathrm{S} 43$

Hyten, D., S189

Hyten, D. L., S61

Iandolino, A., 1089

Ibaragi, K., 436

Ibekwe, A., S144

Ibrahim, D., S84

Idris, A. M., S50, S53, S172

Iglesia-Garcia, A., S142

Iglesias, C., S95
Iglesias-Garcia, A., S53

Ignatov, A., S207

Ikeda, K., 840

Ilarvirus sp., in ligustrum, S112

Ilori, C. O., S92

Imidacloprid, for Xanthomonas citri subsp. citri, S42

Immunocapture RT-PCR technology, virus detection using, S139

Impatiens necrotic spot virus, NSm proteins of, S70

ImpmIPE, food security and, S181

Inderbitzen, P., S64

Inderbitzin, P., S53

Indole-3-acetic acid, in potato purple top phyto-

plasma-infected tomato plants, S206

Induced systemic response (ISR)

compost water extracts for control of Phytophthora capsici on pepper and, 774

integrated pest management and, S165

Pseudomonas chlororaphis $\mathrm{O6}$ for biological control and, S158

Ingram, D. M., S5, S49

Innate immunity, pattern recognition receptors in, S 157

Integrated pest management, induced resistance and, S165

Intergenic spacer region, of Verticillium dahliae, S79

Iodomethane, for Meloidogyne javanica on carrot, S135

Ioos, R., 105

IPI-O, and broad-spectrum resistance against Phytophthora infestans in potato, S46

Ipomoea batatas (sweet potato), S95

Iprodione

for Botrytis cinerea on strawberry, S6

ELISA kits for analysis of residues on creeping bentgrass, S64

Iprovalicarb, for Phytophthora capsici, 1162, S74

IR-4 Project

challenges and successes of registration process, $\mathrm{S} 162$

fungicide registration update, $\mathrm{S} 126$

Irey, M., 567, S24, S200

Iris yellow spot virus (IYSV)

complementation between viruses in datura, and movement of gene silencing suppressor, S10

Thrips tabaci and Frankliniella fusca as vectors for, $\mathrm{S} 122$

Irish-Brown, A., S69

Iron sulphur gene $(D b S D H B)$, and fungicide

resistance in Didymella bryoniae, $\mathrm{S} 9$

Ironwood tree. See Casuarina equisetifolia

Irrigation water

Phytophthora spp. in, S47, S51

Pseudomonas cannabina pv. alisalensis in S79

Isakeit, T., S54, S106

Isakeit, T. S., S153

Ishida, Y., 85

Ishiga, T., S54, S160

Ishiga, Y., S54, S129, S160

Ishii, Y., S52

Ishikawa, K., 612

Ishimaru, C., S59

Ishimaru, C. A., S54, S120, S124

Islam, M. A., 356

Ismail, S., S54

Isoparaffin-based oil, for controlling dollar spot and gray leaf spot in turfgrass, S208

Ithal, N., S58

Ito, T., 922

Ivey, M., S124

Ivey, M. L., S33

Ivors, K., S55

Ivors, K. L., 732, S52

IVR (inhibitor-of-virus-replication) gene, and resistance to Botrytis cinerea, 225, 400

Izumi, Y., 120

Izumori, K., 85

Izzo, A., S134

Jackson, A., S202

Jackson, E. W., 484, 511

Jackson, K., S55

Jackson, K. L., S142

Jackson, T., S182, S183

Jackson, T. A., S180, S187

Jacobs, J. M., S55

Jacobsen, B. J., S87, S165, S168

Jacon, G., S27

Jagadeeswaran, G., S3

Jaime-Garcia, R., S55

Jain, R., S59

Jalan, N., S55

Jan, F., S53, S146

Jang, S., S97

Janisiewicz, W. J., 42, S56, S58

Janousek, C. N., S17

Jansky, S., S19

Japanese oak wilt, Raffaelea quercivora and, spatial distribution in xylem, 747

Japanese pear. See Pyrus pyrifolia

Japonica rice landraces, QTL in for broadspectrum resistance to, 822

Jaraba-Navas, J., S75

Jardine, D., S185

Jarugula, S., 698, S56

Jasmonic acid

Cucumber mosaic virus 2b RNA silencing suppressor and, S70

Fusarium oxysporum on melon and production of, modification by Trichoderma harzianum and Glomus intraradices, 682

plant immunity and, S160

Jayaraj, J., S18, S205

Jayasena, A. S., S56

Jeffers, S. N., S150

Jeffries, P., 814

Jeger, M. J., 814

Jellison, J., S21

Jenkins, D. M., S66

Jeon, A., S56

Jeon, J., S97

Jeong, M., S25

Jeong, R., S56

Jeyaraman, R., S56

Ji, C.-Y., S96

Ji, P., S55 S57, S142

Jia, M., S202

Jia, Y., S202, S204

Jiang, T., S57

Jiang, Y., S206, S207

Jicama, Phakopsora pachyrhizi on, in U.S., S29

Jimenez, P., S13, S19, S129

Jin, J., S187

Jin, X., S57

Jin, Y., 432, S93

Jo, Y., S57

Joannon, B., 1373

Johal, G., S11

Johnson, B. J., 532, S1

Johnson, C., S97

Johnson, D., 271

Johnson, D. A., S31

Johnson, E. G., S57, S173

Johnson, K., S148

Johnson, K. B., 1330, S166

Johnson, R. M., S43

Johnson, S. B., S194

Johnston, J. A., 97

Johnston, R. H., 97

Jomantiene, R., S29, S206

Jones, D., 567, S24

Jones, J., S36

Jones, J. B., 208, S13, S22, S103, S172, S173 
Jones, S., S147

Jonkers, W., S75

Jordan, R., S59, S143

Jordan, R. L., S10, S154

Jordan, S. A., 941, S174, S175

Joseph, L., S26

Joshua, J., S84

Jossey, S., S57

Judelson, H., S140

Judge, C. A., S102

Juglans spp. (walnut)

Agrobacterium tumefaciens on seeds used for rootstock production, S141

Brenneria rubrifaciens on, rpo $\mathrm{N}$ and, $\mathrm{S} 80$

Geosmithia morbida on, status in California, S48

Jumpponen, A., S41

Jung, G., S92, S102, S197

Jung, H., S160

Jung, K., S25, S65

Juniperus occidentalis (juniper), phytoplasma on, S206

Jurick, II, W. M., S56

Jurick, W., S58

Jurick II, W. M., 42

Juvale, P. S., S187

Juzwik, J., 979

K. O’Donnell, 1176

Kabbage, M., S45, S58, S160

Kabeil, S. S., S1

Kablan, L., S58

Kachroo, A., S38, S56, S58, S117, S119, S139

Kachroo, P., S56, S58, S139

Kadooka, C. Y., S128

Kaitheri Kandoth, P., S58

Kakizawa, S., S52

Kakvan, N., S6

Kale, S. D., S158

Kalifa, H. B., 913

Kalmowitz, K. E., S60

Kalpana, K., S59

Kamber, T., S59, S120

Kamenidou, S., S59

Kammerer, S., S152

Kamo, K., S59

Kamo, K. K., S67

Kandel, Y. R., S59

Kanematsu, S., 922

Kaneshiro Sueno, W., S78

Kanetis, L., 738

Kang, S., 732, S25, S64, S79, S97, S150

Kang, Z., S53, S133

Kano, A., 85

Kantartzi, S. K., S28

Karakaya, A., S15

Karakkat, B., S59

Karasev, A., S61

Kariuki, G. M., S60

Karki, H., S47

Karlovsky, P., 444

Karthikeyan, G., S101

Kasugamycin, overview of, S166

Katan, J., 367

Kattan, A., 532

Kaufman, H. W., S153

Kaur, P., S60

Kav, N. N., S130

Kazan, K., S75

Kearney, S., S17

Keese, R. J., S60

Kegley, A. J., S120

Keinath, A. P., S60, S201

Keller, K., S67

Keller, M., S40

Kelley, E., S60

Kemerait, R., S57

Kemerait, R. C., S37, S92, S200, S202

Kendall, A., S60
Kendrick, M. D., S61

Kenerley, C. M., S27

Kennelly, M., S91

Kenney, M. J., S61

Kentucky bluegrass. See Poa pratensis

Kephart, K. D., 97

Kerlan, C., S61

Kerns, J., S64, S137

Kerns, J. P., S120

Kerrigan, J. L., S204

Kersbergen, R., S194

Kersey, C., S61

Kessel, G. J. T., 1146

Khalaf, A. A., S61

Khan, M., S25

Khan, M. F., S102

Khan, M. F. R., 689

Khan, N. I., S61

Khattab, A., S4

Khazaeli, P., S62

Khodzaeva, A., 593

Khozeini, F., S83, S124

Khudokormova, Z. N., S65

Kidney bean, soybean cyst nematode on, S102

Kilcrease, J., S62

Killiny, N., S62

Kim, D., S25, S97

Kim, H., S58, S62, S97, S160

Kim, J., S62

Kim, J.-G., 774

Kim, K., S41, S62

Kim, K. D., 774

Kim, R., S116

Kim, S., S97, S161

Kim, W., S25

Kim, Y., S63, S96, S143, S158, S163

Kinard, G., S71, S72, S101

Kinases, of Fusarium graminearum, S151

Kinyua, Z. M., S60

Kirk, W. W., S9

Kirkpatrick, T., S75

Kirkpatrick, T. L., S114, S153

Kiseleva, M. I., S65

Kiss, E., 863

Kiss, L., S19

Kistler, C., S75

Kito, H., S63

Klappach, K., S63

Klassen, W., S176, S178

Kleinhenz, M. D., S20

Klessig, D., S77

Kliebenstein, D. J., S165

Kliejunas, J. T., S94

Klieman-Shoval, S., 798

Klindworth, D., S93

Kline, T., S160

Klittich, C. J., S63

Kloepper, J., S18, S146

Kloepper, J. W., S63, S65, S165, S170

Klosterman, S. J., 1222, S64, S79, S98, S107

Klouser, L., 97

Kluepfel, D. A., S141

Knapp, S. J., S105

Knauf-Beiter, G., S66

Koa. See Acacia koa

Kobayashi, D., S98

Koch, P., S64, S137

Koebnik, R., S8

Koehrsen, M., S64, S75

Koike, S. T., S14, S107, S140, S155

Kojima, N., S52

Kolander, T. M., S187

Kolmer, J. A., 376

Kolomiets, M., S96

Kolomiets, T. M., S64, S65

Komar, V., 384

Koné, D., S142

Kong, M., S64

Kong, P., 632, S51, S207
Kong, S., S65, S97

Koornneef, A., S160

Kopperud, K., S11

Korban, S. S., 192, S107

Korus, K. A., S187

Kouassi, N., S65

Kousik, C., S134, S201

Kousik, C. S., 1194, S65

Koval, N. C., S34

Kovalenko, E. D., S65

Krakowsky, M., S114

Krakowsky, M. D., 72

Kramberger, P., S81

Krampis, K., S190

Kreiser, B., S83, S134

Krishna Kumar, V., S65

Krishnam Raju, S., S65, S170

Kriss, A. B., 784, S65, S66

Kroll, J., S9

Kubota, R., S66

Kudzu. See Pueraria spp.

Kuhar, T. P., S205

Kuhn, P., S66

Kuldau, G. A., S44

Kumar, K., S146

Kumquat. See Fortunella spp.

Kunjeti, S. G., S66, S207

Kunkel, D., S162

Kunta, M., S66

Kuo, K., S71

Kurle, J. E., S66, S187, S188

Kurowski, C. J., 972

Kwak, Y.-S., 404

Labavitch, J. M., S9

Labbé, C., S198

Labyrinthula terrestris, on turfgrass, S204

Lacey, L., S55

Lackermann, K., S67

Lacy, G. H., 208

Laflamme, G., S194

Lagenaria siceraria (bottle gourd), Phytophthora capsici on, S65

Lahaye, T., S36, S159

Lahlali, R., S99

LaHue, S. S., S28

Laird, E., S94

Lak, M., S84

Lakatos, P., S51

Lakshman, D. K., S6, S67

Lalancette, N., S195

Lambert, D. H., S194

Laminated root rot (LRR), Douglas fir seedlings infected with Phellinus sulphurascens, 356

Lamondia, J. A., S195

Lamour, K., S41

LAMP (loop-mediated isothermal amplification) for Ralstonia solanacearum race 3 biovar 2, S66

for rapid detection of Phytophthora spp., 143 for Xylella fastidiosa, 1282

Lamppa, R. S., S185

Lan, C. X., 313

Land Grant University, S168

Laney, A. G., S67, S201

Lange, H. W., S20

Langston, D. B., S9, S126

Lansdell, T., S54, S59

Lapidot, M., 798

Lapochkina, I. F., S65

Larkin, R. P., S67, S92

Larsen, H., S101

Larsen, M., S42

Larsen, R., S68, S128

Larsen, R. C., 972

Lartey, R. T., S68

Lasiodiplodia theobromae, on rambutan, in Mexico, S89

Lassiter, E. S., S68 
Laurel wilt, Raffaelea lauricola and, quantification of propagules of from redbay ambrosia beetle, 1118

Lauter, N., S157

Lava Kumar, P., S92, S113, S117, S126

Lavigne, C., 1373

Lawrence, A., S112

Lawrence, C., S158

Lawrence, K. K., S170

Lawrence, K. S., S20, S21, S65, S86, S118, S153

Lawrence, N., S114

LC-M/MS, for mycotoxin detection, S108

Le, M. H., S68

Leach, J. E., S127, S157, S164, S167

Lea-Cox, J., S51

Leaf wetness duration

Alternaria alternata on citrus, temperature and, S85

wheat disease epidemiology and, S76

Leafhoppers. See Graminella nigrifrons; Macrosteles quadrilineatus

Leal, R. Acosta-, 1204

Leandro, L., S30, S187, S188

Leandro, L. F., S80

Leatherleaf fern. See Rumohra adiantiformis

Lecanosticta acicola, PCR for detection of in pine, 105

Lecoq, H., 1373

Ledbetter, C., S119

Lee, I., S29, S69, S135, S208

Lee, I.-M., S206

Lee, M., S24, S25, S68, S71

Lee, R., S77

Lee, R. D., S57

Lee, R. F., S46, S107

Lee, S., S204

Lee, S. A., 539, S68

Lee, S.-W., 1089

Lee, Y., S25, S41, S62, S64, S65, S96, S97

Lefebvre, F., S198

Legler, S., S19

Legler, S. E., 1321

Legreve, A., S26, S58

Legrève, A., 474

Lehman, B., 539

Lehman, M., S181

Leibman, D., 225, 798

Leifsonia xyli, on sugarcane, rtPCR method for analysis of early colonization, S21

Leisner, S. M., S107, S144

LeJeune, J. T., S155

Lemaire, O., 384

Leman, S., 208

Lemmetty, A., S88

Leng, Y., S69

Lentinula edodes (Shiitake), global expansion in gourmet and medicinal cultivation, S163

Lenzi, L., 58

Leonard, W., S69

Leonberger, A. J., S69

Leon-Reyes, A., S160

Lepoint, P., 474

Leptosphaeria spp., on canola

screening for resistant lines, S77

TaqMan assay for detection and differentiation of, S69

Lerat, S., 91

Lesion nematodes. See Pratylenchus penetrans

Leslie, J. F., 904

Lesniak, K. E., S69

Letousey, P., 424

Lettuce

Bremia lactucae on, S66

Rhizoctonia spp. in, S13

Sclerotinia spp. on, S24, S91

Verticillium dahliae on, $\mathrm{S} 8$

Leuconostoc mesenteroides, on sugar beet, cultivar selection for resistance, $\mathrm{S} 123$

Leung, H., S11, S157
Leveau, J., S158

Leveillula taurica, and biochar, induction of systemic resistance against, 913

Levesque, C., S153

Lévesque, C. A., 732, S150

Levy, L., S73

Lewandowski, D., S69

Lewandowski, D. J., S70, S191

Lewis, K. J., S132

Lewis, P., S70

Lewis, R., S116

Lewis Ivey, M., S155

Lewsey, M. G., S70, S147

Li, B., S70, S75

Li, C., S104

Li, F., S140

Li, G., S133

Li, H., 551, 890, S35, S39

Li, H. P., 183

Li, J., S71, S72

Li, N., S38

Li, P., 822

Li, Q., S133

Li, R., S71, S72, S101, S140

Li, S., S70, S70 S75, S127

Li, W., S70, S134

Li, X., 183, 573, S69, S70

Li, Y., S71, S105

Li, Z., S70

Liang, S. S., 313

Liang, Y., S130

Liang, Z., S118

Liao, C., S71

Liao, H., S72

Liao, Y. C., 183

Liberti, D., S201

Liesche, R., S53

Life sciences, dual-use research in, S70

Lignin biosynthesis, in sorghum, resistance against Fusarium spp. and, 671, S37, S185

Ligustrum, new ilarvirus infecting, S112

Lijuan, Z., S30

Lim, H., S71

Lim, H.-J., 1089

Lim, K., S188

Lima bean. See Phaseolus lunatus

Limay-Rios, V., S180

Lime-sulfur, for sooty blotch and flyspeck on apple, S197

Lin, H., S30, S41, S71, S72

Lin, J., S105

Lin, L., S71, S72

Lin, Y., S1

Lindeberg, M., S72

Lindow, S. E., S136

Ling, K., S72, S139

Lipopeptides, differential roles of in plant host

defenses and pathogen suppression, S158

Lipopolysaccharide, of Xanthomonas axonopodis pv. citri, biofilm formation and virulence, S71

Lipoxygenases, and Aspergillus flavus on maize, aflatoxin accumulation and, S96

LiPuma, J. J., S31

Lithocarpus densiflorus (tanoak), Phytophthora ramorum on, S115, S167

Little, C. R., S90, S106

Little, D., S102

Littlefield, L. J., S153

Liu, B., S73

Liu, C. J., 1276

Liu, H., S44, S72, S74, S140

Liu, J., S105

Liu, L., S188

Liu, Q., S73

Liu, R., S73

Liu, T., S105

Liu, W., S73

Liu, X., S74

Liu, X. L., 1162
Liu, Y., S74

Liu, Y. X., 1276

Liu, Z., S73, S74

Livingston, W. H., S195

Lloyd, A. L., 959

Loblolly pine. See Pinus taeda

Locke, J. C., S74

Loebenstein, G., 225

Lolium perenne (perennial ryegrass) isoparaffin-based oil for controlling dollar spot and gray leaf spot in, S208

temperature shifts and, de-acclimation/reacclimation response, $\mathrm{S} 184$

Long, D., S131

Long, S., S120

Longidorus iranicus, in Golestan National Park in Iran, S124

Loope, L., S128

Loper, J. E., 1330

Lopes, S., S74

Lopes, U. V., S42

López, C. E., S127

Lopez Nicora, H., S74

Lord, W., S196

Lore, J., S136

Lorek, J., S158

Loschinkohl, C., S1

Lou, V., S30

Lourenço, E., 300

Lourenço, S. A., S41

Louws, F., S73

Louws, F. J., S21, S73, S106, S109

Low 18:1- derived defense pathway, WRKY proteins and, S38

Lozano, G. L., S39

Loza-Reyes, E., S35

Lozovaya, V. V., 897

Lsi genes, for silicon transport in wheat, S196

Lu, H., S151

Lu, P., S202

Lu, Q. L., 313

Lu, S., 1298, S44, S151

Lu, X., 931, S70, S75, S100

Lu, X. H., 1162, S74

Lubberstedt, T., S184

Lucas, J. A., S12, S51

Luckman, G. A., 460

Lumazine synthase, in transgenic tobacco, ectopic expression and defense responses, 573

Luna fungicides, for control of disease of horticultural crops, S37

Lund, S. P., S136

Luo, L., S72

Luque, A., 58

Luster, D. G., S75, S127, S202

Lygin, A. V., 897

Lyngkjær, M. F., 21

LysM-containing receptor-like kinase 1, and chitin signaling and fungal resistance in Arabidopsis, S68

Lysobacter enzymogenes, type IV pili of, S98

Ma, B., S75, S76

Ma, H. X., 1276

Ma, J., 1276, S75

Ma, J. X., 522

Ma, L., S64, S75

Ma, P., S70, S75

Ma, W., 593, S206

Ma, X., 551

Ma, Z., S132

Macana virus disease, Olpidium virulentus on fique in Colombia, S42

Macaulay, K., S70

MacDonald, A., S70

MacDonald, J. D., 871, S104

MacDonald, W. L., S167

MacGuidwin, A., S26

MacGuidwin, A. E., S180 
MacHardy, W. E., S196

Machbash, Z., 798

Mackasmiel, L., S84

Mackenzie, S., S75

MacLean, D., S70

Macroarrays, for detection of turfgrass pathogens, S90

Macrophomina phaseolina

on cluster bean, S23

on medicago, S118

on soybean, $\mathrm{S} 31$

on sunflower, $\mathrm{S} 128$

Macrosteles quadrilineatus (aster leafhoppers),

aster yellows phytoplasma and, S33

Madagascar periwinkle. See Catharanthus roseus

Madariaga, M., S110

Madden, L., S132, S137

Madden, L. V., 160, 784, 1015, S6, S65, S66, S81, S113

Maddux, L. D., S41

Madeiras, A. M., S195

MADS-box family of transcription factors, in

Fusarium verticillioides, S94

Maejima, K., S52

Maffia, L. A., S121

Magarey, P. A., 1240, S38

Magculia, N., S136

MAGIC (Mutant-Assisted Gene Identification and

Characterization), S11

Magill, C. W., S106

Magnaporthe spp.

M. grisea, QTL in Japonica rice landrace responsible for broad-spectrum resistance to, 822

M. oryzae

AVR-Pita gene of, 612, S204

Bacillus spp. for inhibition of, S106

bZip proteins in, S65

conidiation of, genes expressed during, S62

ethylene biosynthesis and resistance to, S49

Forkhead-box protein in, S97

genetic stability of isolates on host and artificial media, S97

$M o C D C 15$, conidiation and pathogenicity, S41

Nep1-like toxin from, S74

nitroalkane dioxygenases in morphogenesis and infection, S137

$P i 34$ gene and resistance against, S63

Pigm gene and broad-spectrum resistance, S49

Pik locus of rice and, $\mathrm{S} 96$

$P i-z(t)$ gene and, S202

$P W T 1$ avirulence allele of and recognition by wheat and barley, 436

rice $P R O P E P 1-7$ and, $\mathrm{S} 73$

Magnusson, V., S18

Mahmoodi, B., S13, S113

Mahoney, N. E., S95

Mahto, B. N., S76

Mahtour, A., S76

Mahuku, G., S119

Maia, G. S., S40, S174

Maier, T., S58

Maier, T. R., S186

Mailhot, D. J., 941

Maize. See Zea mays

Maize fine streak virus (MFSV)

plant host range and leafhopper transmission of, 1138

production of in Drosophila S2 cells, factors influencing, S26

transient expression of in Drosophila S2 cells, S184

Maize streak virus (MSV), resistance in test crosses of early generation lines, S113

Majerczak, D. R., S27, S184
Malapi-Nelson, M. M., S76

Malus $\times$ domestica (apple)

apple proliferation (AP) disease of, 390

Botrytis cinerea on, S63, S143, S163

Candidatus Phytoplasma mali and, 863

Colletotrichum gloeosporioides on, $\mathrm{S} 122$

Erwinia amylovora on, 532, S12, S68

multiple virus infections in, in Colorado, S101

Penicillium expansum on, S2, S63, S93, S163

sooty blotch and flyspeck fungi on, 345, S15, S54

Venturia inaequalis on

fungicide resistance in, S23, S27, S100, S183, S189

post-harvest foliar urea sprays for, S196

winter pruning and powdery mildew, S51

Malvick, D., S185

Malvick, D. K., S14, S66, S187

Mammella, M. A., S76

Manabayeva, S. A., S76

Mandal, M. K., S58

Mandevilla splendens, Pseudomonas savastanoi on, $\mathrm{S} 104$

Mango malformation disease (MMD), Fusarium

mexicanum and, 1176, Cover photo November

Manihot esculenta (cassava) cassava frogskin disease of, S5

Xanthomonas axonopodis pv. manihotis on, S8, S86, S127

Manjunath, K. L., S46, S77, S107

Mankolo, R. N., S91

Mann, R. B., S167

Manners, J., S75

Manners, J. M., 1276

Manning, V. A., S160

Mano, E. T., S77

Manoranjitham, K., S101

Manosalva, P., S77

Manosalva, P. M., S164

Mansfield, M., S77

Mansfield, M. A., 732, S195

Mansfield, M. E., S77

Mantoe, L., S66

Manulis-Sasson, S., 252, S22

MAPK (Mitogen-activated protein kinases), in

Cochliobolus sativus, S69

Marafivirus sp., in blackberry, S112

Marahatta, S. P., S133

Maraite, H., 474, S32

Marçais, B., 105, 1262

Marchites spp., on oil palm, in Peru, S125

Marek, S., S131

Marek, S. M., 415, S7

Marett, C. C., S190

Margenthaler, E., S129

Marin, D. R., S118, S119

Marino, D. A., S77

Markell, S., S185

Marlow, G., S111

Marois, J., S181

Marois, J. J., 941, 1111, S122, S143, S178, S186, S204

Maroof, S., S189, S190

Maroon-Lango, C. J., S1, S78

Marques, A., S114, S207

Marquez-Villavicencio, M., S78

Marra, R. E., S195

Marrero, G., S78

Marsh, A. G., S66, S207

Martin, B., S152

Martin, F., S14

Martin, F. N., 732, 1231, S14, S76, S78, S150, S152

Martin, G. B., S92

Martin, K., S11

Martin, R., S67

Martin, R. R., 698, S106, S110

Martinez, M. C., S178

Martinez, M. T., S89
Martinez-Espinoza, A., S78

Martínez-Medina, A., 682

Martínez-Romero, E., S20

Martinka, M., S67

Martins, T. D., S78

Maruthachalam, K., 1222, S8, S64, S79, S107

Marx, B. D., S115

Marzachì, C., 805

Mascher, F., 855

Massad, E., 1042

Massola, N. S., S86

Master gardeners, Sick Plants and a Hungry

World online course for, S33

Mastouri, F., 1213, S165

Masunaka, A., 120

MAT (mating type) loci genes

for differentiation of Pyrenophora teres $\mathrm{f}$. teres from P. teres f. maculata, 1298

of Pyrenophora tritici-repentis on wheat, genetic diversity of, 474

Matheron, M. E., S79

Matias, A. C., S99

Mating pheromones. See Pheromones

Matsushita, N., 747

Matthews, B. F., S127

Mattupalli, C., S79, S188

Matute, E. J. Graterol-, 172

Maul, J., S51, S207

Mauzey, S. J., S79

Mavrodi, D., S142

Mavrodi, O., S142

Mavrodieva, V., S73

Mayetiola destructor (Hessian fly), $H$ gene and resistance to, 279

Mayfield, A. E., S177

Mayfield, D. A., S15, S54

Maymon, M., 1176

Maynard, C. A., S10, S29, S89, S91

Mayo, J. B., S120

Mazzola, M., S134

Mbofung, G. C., S80

McAvoy, E., S107

McCabe, K. J., S124

McCall, D., S28, S205

McCall, D. S., S80, S152, S208

McClean, A., S80

McCluskey, K., S80

McCoy, S., S122

McCue, K. F., S101

McCullough, P., S78

McDonald, B. A., 172, 855

McDonald, M., S59, S60, S99, S117, S125

McDonnell, K., S17

McDowell, J., S158

McFarland, K., S195

McGahan, D., S16

McGhee, G. C., S166

McGrath, J., S47

McGrath, M., S80, S161

McGrath, M. T., S20, S102, S196, S197

McInroy, J. A., S63, S170

McKenna, F., S34

McKenzie, D., S163

McLeod, A., S20, S52

McMahon, M. B., S75

McMillan, R. T., S174

McMullen, M., S4, S137

McMullen, M. D., 72

McMullen, M. P., 160

McNally, R. R., S80

McNellis, T. W., 539, S68

McPhee, K., S25

McRoberts, N., S81

McSpadden Gardener, B., S158, S159

McSpadden Gardener, B. B., S20, S96

Meacham, T., S61

Meah, B., S11

Mealybugs, and grapevine leafroll viruses, virusvector specificity in, 830 
Medicago truncatula

Asian soybean rust and switchgrass rust on, S129

Macrophomina phaseolina on, S118

Phakopsora pachyrhizi on, S54

Medina, C., S110

Meekes, E., S81

Mefenoxam

for Phytophthora capsici, S20, S195

for Phytophthora erythroseptica on potato, S 183

Mehl, H. L., 150, S81

Mehle, N., S81

Mehra, L., S81

Meinhardt, S., S151

Meitz, J. C., S20

Mejia, J. F., S5

Mekete, T., S74

Mekuria, T., S81, S90

Melaleuca quinquenervia, Puccinia psidii on,

differences in susceptibility and disease

development, S108

Melanin, in Mycosphaerella graminicola, MCC1-

encoding c-type cyclin and, S25

Melanson, R., S47

Melcher, U., S10, S18, S110, S121, S154

Melito, S., S26

Mellinger, C., S134

Melnick, R., S82

MeloCon WG

for control of nematodes and soil-borne disease in vegetable production, S50

for nematodes and soil borne diseases in fruiting vegetables, S200

Meloidogyne spp. (root-knot nematodes)

annular rings for enhancing photographs of perineal patterns of, $\mathrm{S} 32$

M. incognita

activity of monoterpenoids against, 199

on cotton, S75, S202

on cucurbits, S35

Gymnoascus reessii for control of, $\mathrm{S} 105$

secretory protein of interacts with golgiassociated host plant protein, S141

on tobacco, $\mathrm{S} 28$

on tomato in Egypt, S1

on yellow squash, S31

M. javanica, on carrots, $\mathrm{S} 135$

quantification of eggs produced by, S62

on tobacco, and host-derived RNAi targeted to novel parasitism gene, $\mathrm{S} 116$

Melon. See Cucumis melo

Melon necrotic spot virus (MNSV), in cucumber,

S69, S191

Melotto, M., S24, S91

Melzer, M. J., S82

Mendoza, P., S99

Meng, B., S104

Meng, F., S55

Meng, Q., S82

Meng, Y., S56

Mengistu, N., S191

Menkir, A., S113, S117

Mentha sp. (mint)

Tobacco ringspot virus and Strawberry latent ringspot virus in, $\mathrm{S} 109$

Verticillium dahliae on, S77

Mentreddy, S. R., S91

Mergoum, M., S104

Merighi, M., S27, S184

Mersha, Z., S82, S115

Mertely, J. C., S83, S174

MES1 gene, and systemic acquired resistance against Phytophthora infestans in potato, S77

Metabolic fingerprinting, for Fusarium verticillioides, $\mathrm{S} 120$

Metam sodium, microbial aspects of accelerated degradation of in soil, 367

Methyl bromide, alternatives to, for nematodes and soil borne diseases in fruiting vegetables, S200

Methyl isothiocyanate (MITC), microbial aspects of accelerated degradation of in soil, 367

Metrafenone, for control of Plasmopara viticola and Erysiphe necator on grape, S136

Meyer, F. W., S197

Meyer, P. W., S188

Meyers, B. C., S66, S207

$M f P G$ genes, in Monilinia fructicola, regulation and functional characterization of, S25

Mian, R., S192

Michailides, T. J., 1340, S48, S83, S141

Michel, A. P., S33

Microarrays

for universal plant virus detection and identification, $\mathrm{S} 10$

viruses and, S154

Microbial Rosetta Stone (MRS) Central, overview of, S59

Micro-RNAs (miRNA), in host infected with

Grapevine leafroll-associated virus 3, S3

Microsatellite markers

for assessment of diversity of Phytophthora sojae, $\mathrm{S} 123$

for taxonomic identification of Phytophthora spp., S29

Miedaner, T., 904

Miglino, R., S81

Miklas, P. N., 972

Mila, A., S14

Mila, A. L., S100

Miles, T. D., S9, S83

Milgroom, M. G., 1185, S20

Milks, D., S55

Miller, J. D., S180

Miller, M., S65

Miller, S. A., S13, S20, S33, S124, S140, S155

Miller, S. I., S160

Miller-Butler, M., S83

Millhouse, J., S191

Milling, A., S55, S115

Milstop, for control of powdery mildew on cucurbits, S80

Milus, E. A., S203

Mimee, B., S193

Minenkova, O., S143

Ming, R., S182

Mingora, C., S94

Minsavage, G. V., S103

Mint oils, for control of Rhizoctonia solani on tomato, 493

Minz, D., 367

Minzenmayer, R. R., S54

Mirzaee-Qomi, M., S83

Mirzaee-Qomi, P., S84

Misaghi, I., S122

Miscanthus $\times$ giganteus plant diseases in, S3, S180

potential viral threats to in United States, S3 response to fungal pathogens, S17

Misra, A. K., S96

Mitchell, F. L., S88

Mitchell, M. N., S84

Mitchell, T., S10

Mitchell, T. K., 415

Mitchum, M., S187

Mitchum, M. G., S58, S108, S116, S132, S186

Mitkowski, N. A., S23

Mitochondrial haplotype analysis, for differentiation of Verticillium dahliae races, 1231, S78

Mitra, A., S38, S67

Mittal, S., S54, S129

Mitter, N., S10

Miwa, E., S143

Mixed-modeling approaches, for characterizing profiles of time-varying response and predictor variables, 1015
Miyamoto, Y., 120

Mizzau, M., 390

Mlo locus, and resistance of barley against

Blumeria graminis f. sp. hordei, S158

MLST. See Multilocus sequence typing

Mmbaga, M. T., S84

MMD. See Mango malformation disease

$M o C D C 15$ gene, and conidiation and pathogenicity of Magnaporthe ozyzae on rice, S41

Mock, N., S95

Mock, R., S56, S71, S72, S101

Modarresi Chahardehi, A., S84

Modeling

for characterizing profiles of time-varying response and predictor variables, 1015

of Cladosporium caryigenum, $\mathrm{S} 98$

climate change and, S179

climate change and potato late blight risk, S121

competition between viruses on complex plant-pathogen system, 1042

of efficacies of pathogens in relation to characteristics of biocontrol agent, 814

of Fusarium graminearum on barley, S15 of ironwood tree decline in Guam, S115 of Phytophthora alni-induced alder decline, 1262

of Phytophthora infestans outbreaks, S92

of Plasmopara viticola on grape, S194

of Podosphaera macularis on hop, S40

of Pseudoperonospora cubensis, 959, S202

of Puccinia striiformis f. sp. tritici longdistance transport, $\mathrm{S} 132$

of Puccinia triticina, S32

of Sclerotinia sclerotiorum, S89, S184

of selection for fungicide resistance, S51

of septoria wheat leaf blotch, S32, S63

SkyBit for, S46

Moeller, J., S188

Mohammad Deimi, A., S84

Mohammadi, A., S85

Mohammadi, M., S85

Mohan, K., S113

Mohd Jaaffar, A., S85

MoHOX2, in Magnaporthe oryzae, expression during conidiation, S62

Momol, T. M., S22, S173

Monacell, J. T., S85, S92, S157

Monarda spp., essential oils from, for control of

Rhizoctonia solani on tomato, 493

Mondal, S. N., S85, S86, S174

Monfort, W. S., S121

Monger, W., S154

Monilinia spp.

cytochrome b gene and fungicide resistance, S50

M. fructicola

on decayed stone fruits in West Virginia, S56

on peach, S119

polygalacturonase genes of, S25

Moniliophthora perniciosa, on cacao, genetic variation and adaptation of isolates in Brazil, S42

Monosporascus cannonballus, on melon, Olpidium bornovanus and, S122

Monoterpenoids, activity of against Meloidogyne incognita, 199

Monteiro-Vitorello, C. B., S21

Montenegro, N., S86

Montesinos-Herrero, C., S86

Montmorency stem pitting virus (MMSPV), in sweet cherry, S130

Montoya Piedra, Y., S125

Montpetit, J., S196

Moore, G. A., S61

Moore, G. G., S157

Moore, J. A., 279

Moore, S. R., S86 
Moore, W. F., S112

Moorman, G., S51

Moorman, G. W., S153

Mora, R., S110

Moraes, S. G., S86

Moral, J., 1340, S86

Morales, J. G., S40, S87

Morales Ruiz, S. S., S125

Morales-Payan, J., S176

Morales-Pedraza, L. G., S87

Morano, L., 601

Morano, L. D., S115, S116

Moreau, J., S26

Moreira, A. S., S87

Moreira, R., S42

Morgan, D., S83

Morid, B., S32, S62, S101

Moriones, E., 582

Morisaka, H., 1289

Moriwaki, J., 612

Morris, C. E., 208

Morris, T., S105

Morrison, E. N., S87

Morse, J. G., S118

Moscou, M., S157

Motavalli, P., S41

Mottet, M.-J., S196

Mou, B., S107

Moulin, M., S70

Mount, L. L., S174

Mousavi, L., S87

Moya, E. A., S87

Moyer, M. M., 1240, S38, S88

Mozafari, J., S84, S87

Msikita, W., S88

$\mathrm{Mu} \pm$ oz, M. P., S110

Mueller, D. S., S14, S182

Mueller, J. D., S153

Muilenberg, M. M., S208

Mukhina, Z. M., S64

Mulard, G., 1352

Mulat, H. K., S88

Mulcahy, A., S93

Mulch

bio-enhanced organic for control of nutsedges in tomato, $\mathrm{S} 176$

with biofungicides for managing diseases in tomato in, S91

polyethylene, for managing diseases in organic tomato production, S91

Multilocus sequence typing (MLST), of Xylella

fastidiosa causing Pierce's disease and oleander leaf scorch, 601

Mung bean. See Vigna radiata

Munkvold, G., S28, S30, S36, S148, S185

Munkvold, G. P., S109, S180, S184

Muñoz, M. P., S110

Muñoz-Díez, C., 1340

Munyaneza, J. E., S88

Mur, L. A. J., 21

Muramoto, J., S19

Murphy, A., S147

Murphy, A. M., S70

Murphy, D., S200

Murphy, J. A., S109, S197

Murphy, J. F., S118, S130

Murray, J., S182

Musa spp. (banana, plantain)

benlate and, S170

Cylindrocladium spathiphylli on, S58

Fusarium oxysporum f. sp. cubense on, S146

Mycosphaerella fijiensis on, S5, S58

Musetti, R., 390

Mushroom

disease management in commercial facilities, S164

global expansion in gourmet and medicinal cultivation, S163

Muskmelon. See Cucumis melo
Musso, C., 805

Musson, G. H., S37, S100

Mustard cover crops, for management of Phytoph-

thora capsici on cucurbits, S126

Mutschler, M. A., S147

Myclobutanil

for Podosphaera xanthii, S16

for Venturia inaequalis, on apple, S23

Mycorrhizal infection, and sorghum allelopathy

against wheat, S2

Mycosphaerella spp.

M. fijiensis, on banana, S5, S58

M. graminicola

airborne inoculum of during growing season in Belgium, S26

MCC1-encoding c-type cyclin, S25

NOXa and pathogenicity, S25

succinate dehydrogenase inhibitor for, S12 on wheat, S45

Mycotoxins

of Aspergillus section Nigri on maize and peanuts, S10

diversity of in Aspergillus pasasiticus and A.

flavus, S157

Fusarium graminearum and, 290, 436

in maize, S4, S109

testing for using LC-MS/MS, S108

Mycoviruses

in grapevines, S5

from Rosellinia necatrix, 922

Myers, B. A., S88

Myers, K. L., S52

Myers, M., S42

Myrothecium verrucaria, effect of surfactants on

conidial germination, S57

Mysore, K. S., S54, S129, S160

N-stez, C. E., S87

Nadal, M., 1364

Nadler, S. A., S113

Nagashima, S., 612

Naidu, R. A., 698, S3, S45, S56, S81, S101

Nair, S., S116

Nakajima, T., 763, S63

Namba, S., S52

Narvaez, D. F., S143, S178, S186, S204

National Clonal Germplasm Laboratory, S3

National Plant Diagnostic Network (NPDN),

S168, S177, S181

National Plant Microbial Germplasm Collection, S167

National Science Advisory Board for Biosecurity

(NSABB), S70

Natwick, E. T., S12, S138

Naumann, T. A., 645, S88

Nava, C., S89

Navarre, D., S38

Navas-Castillo, J., 582

Navi, S. S., S89, S144

Neal, J. C., S102

Nearctaphis bakeri, and transmission and evolution of soybean dwarf virus, S126

Neate, S. M., S43

Nectarine. See Prunus persica

Negeri, A., S11

Neil, G., S93

Nelson, B. D., S4, S102, S111

Nelson, L., S191

Nelson, M. E., S40, S73, S138, S188

Nelson, R. J., S156

Nelson, R. S., S142

Nelson, S. C., S82

Nematodes. See also Specific nematodes

cereal cyst nematode, 216

on corn in midwest, S180, S182

effector proteins of, mode of action, S179

evaluation of brassicacious greens for control of, S123

Longidoridae and Trichodoridae from Gole- stan National Park in Iran, S124

surface coat proteins of, during host pine

infection and in vitro culture, 1289

Nemchinov, L. G., S208

Nepal, A., S89, S189

Nephelium lappaceum (rambutan)

fungal diversity associated with in Puerto Rico, S176

Pestalotiopsis thea and Lasiodiplodia theobromae on, in Mexico, S89

NepI-like proteins, of Magnaporthe oryzae, rice protein interacting with, S74

Nepoviruses, characterization of by integrated approach, S81

Net form net blotch (NB), of barley, resistance loci for, 80

Nettleton, D., S58, S136

Network biology, for quantitative genetic variation altering signaling in both plant host and generalist pathogens, S165

Neu, K., S23

Neufeld, K., S89

Neufeld, K. N., 959, S202

Neves, A. A., S77

New York State Agricultural Experiment Station (NYSAES), partnership with Geneva City School District, S20

Newcomb, M., 986

Newhouse, A. E., S89

Newman, M. A., S153, S202

Newsom, L. J., S57, S131

Nga, N. T. T., 436

Ngugi, H. K., 539, S11, S46, S49, S68, S100

Nguyen, H. V., S160

Niblack, T., S185

Niblack, T. L., S74

Nichols, A., S28

Nichols, A. E., S80, S208

Nickerson, J., S70

Nicotiana spp. (tobacco)

Cucumber mosaic virus in, S147

lumazine synthase in, 573

Meloidogyne spp. on, S116

Phytophthora nicotianae on, S97

Ralstonia solanacearum on, S14, S100

root knot nematodes on, S28

Tobacco curly shoot virus in, S52

Xylella fastidiosa on, S29

Nie, J., S69, S70

Nieto, D., S89

Nightengale, S. P., S20

Nikolaeva, O., S61

Nischwitz, C., S89

Nishiguchi, M., S90

Nishizawa, Y., 85

Nissen, L., S199

Nissinen, A., S88

Nita, M., S90

Nitric oxide, and Fusarium verticillioides on maize, $\mathrm{S} 10$

Nivalenol, Fusarium graminearum on wheat and, 763

Njambere, E. N., S90

Noel, M., S136

Noguchi, M. T., 612

Nolan, S., S17

Noll, L. W., S90

Norman, D. J., S15, S90, S103

Northern, L., S89

Northern, L. C., S91

Norton, R., S196

Nosir, W., S95

NOXa, Mycosphaerella graminicola pathogenicity and, S25

NSm proteins, common functional domains of, S70

Nucleic acids, collection and assessment of, assessing new biomaterials for, S19

Nunney, L., 601 
Nusbaum, C., S68

Nuss, D. L., S135

Nústez, C. E., S87

Nutter, F., S183

Nutter, F. W., S42, S186, S188

Nutter, Jr., F. W., S181, S188

Nutter Jr. F.W., 931

Nyochembeng, L. M., S91

NYSAES. See New York State Agricultural

Experiment Station

Oak. See Quercus spp.

Oak, S. W., S150

Oat. See Avena sativa

Obanor, F., 1057

Obasa, K., S91

Obert, D. E., 484

O'Brien, G. K., S178, S204

Obulareddy, N., S91

$O c c$ gene cluster, and occidiofungin production by

Burkholderia contaminans, S44

Occidiofungin, from Burkholderia contaminans,

occ gene cluster and, $\mathrm{S} 44$

Ochoa Corona, F. M., S7, S19, S30

Ochratoxin A, in California raisins, and

Aspergillus spp., S95

Ocimum basilicum (basil)

Peronospora belbahrii on, S9, S107, S196, S198

Peronospora sp. on, in Florida, S175

Plectosporium tabacinum on, in U.S., S32

Ockey, S. C., S91

O'Connell, S., S109

O'Donnell, K., 58

Oerke, E., S156

Ofek, M., 367

Ogata, D. Y., S82

Ogle1040 locus, and resistance of wheat against

Puccinia coronata, 484

Ogunsola, K. E., S92

Oh, C., S92

Ohtani, K., 85, 120

Oidium neolycopersici, tomato, climate change and, S33

Oikawa, Y., 922

Oikonomakos, I., S7

Ojiambo, P., S89, S190

Ojiambo, P. S., 959, 1066, S128, S144, S202, S204

Ok, C., S92, S102, S197

Okano, Y., S52

Okazaki, S., 560

O'Keefe, G., 539

O'Keeffe, T. L., 532

O'Keeffe, T. L., S95

Okuda, M., 560

Okuda, S., 560

Olanya, M., S67, S92

Olarte, R. A., S92, S157

Olatinwo, R. O., S92

Olaya, G., S55, S66, S93

Olea europaea (olive)

Botryosphaeriaceae collected from in Spain and California, characterization and pathogenicity, 1340, Cover photo December branch dieback of, in California, S129

Colletotrichum acutatum on, S86

diseases of in Argentina, S99

pervasive latent viral infection of in National Clonal Germplasm Laboratory, S3

Oleander leaf scorch, Xylella fastidiosa and, multilocus sequence typing for, 601

Oleic acid, low 18:1, and signaling and plant defense, S38, S58

Oligoadenylate system (OAS) system, broadspectrum virus resistance using, S38

Oligogalacturonides, and defenses in wheat against powdery mildew, 1352

Olive. See Olea europaea
Oliveira, F. R., S21

Oliver, J. E., S93

Oliver, R., S151

Olivera Firpo, P., S93

Olpidium spp.

O. bornovanus, and Monosporascus cannonballus on melon, $\mathrm{S} 122$

and Melon necrotic spot virus in cucumber, S191

O. virulentus, and Macana virus disease on fique in Colombia, S42

Olson, B. D., S161

Olson, H. A., S94

Olson, M. E., S48

OmpA family outer protein, of Xanthomonas

albilineans on sugarcane, S111

O'Neal, M., S182

O'Neill, N. R., S208

Ong, K., S123

Ong, K. L., S199

Ongena, M., S158

Onion. See Allium cepa

Onoue, M., 922

Oomycete Undergraduate Molecular Genetics

Network (OUMGN), SPACES site, update on, S94

Oomycetes

population genetic insights into emergence of, S150

sequence-based identification of, promise and pitfalls of, 732

Ophiognomonia clavigignenti-juglandacearum, reclassification from genus Sirococcus, S17

Ophiosphaerella spp., on bermudagrass

GFP and RFP in, 415

multilocus phylogeny of, S131

Ophiostoma sp., on Pinus spp. in Lebanon, S111

Opit, G., S30

Orchids. See Cattleya orchids; Phalaenopsis orchids

Ordoñez, M. E., 376

Organic produce

fungicides and, for Colletotrichum orbiculare on cantaloupe, S35

mushrooms, S164

tomato, bio-enhanced organic mulch for control of nutsedges in, S176

Organocide, for control of powdery mildew on

cucurbits, S80

Oriolani, E., S99

Ormeño-Orillo, E., S20

Ornamental flowering cherries, leaf spot disease in, S84

Orobanche spp. (broomrape), biological control of by Fusarium isolates, S34

Orr, G., S166

Ortega, M. A., S189

Ortega-Beltran, A., S39

Ortiz, B. V., S86

Ortiz, C., S94

Orvego, for Peronospora and Pseudoperonospora control in ornamentals, $\mathrm{S} 60$

Oryza sativa (rice) and AVR-Pital, 612

bioinformatic strategies for predicting candidate genes in disease resistance, $\mathrm{S} 164$

Bipolaris oryzae on, S11

Burkholderia glumae on, S96

chromomethylase in, S90

Magnaporthe oryzae on, S97, S137

OsPROPEP1-7 (elicitor precursor genes) of, $\mathrm{S} 73$

protein interacting with NepI-like protein of

Magnaporthe oryzae, S74

Pyricularia oryzae on, S145

resistance to rice bacterial blight, D-allose and, 85

Rhizoctonia oryzae-sativae on, 493

Rhizoctonia solani on in Arkansas, multilocus analysis, S22

divergence from maize-infection populations of, 172

phenotyping the components of resistance, S136

plant growth-promoting rhizobacteria and, S170

screening for bacterial antagonists, S146

Southern rice black-streaked dwarf virus in, S146

Ustilaginoidea virens on, in Arkansas, S125

Xanthomonas oryzae pv. oryzae on, AroQ $\gamma$

chorismate mutase and rice virulence, 262

yield losses with sheath blight diseases of, S201

Osborne, L., S137, S185

Osborne, L. E., S59

OSCAR (One Step Construction of Agrobacterium Recombination-ready plasmids), S98

Oshima, K., S52

Osler, R., 390

Osorio, D. L., S42

Ospina-Giraldo, M. D., S94

Osterbauer, N., S135

Oswald, A., S20

Otero, M. L., S99

Otero-Colina, G., 1176

Otrosina, W. J., S94

Otto-Hanson, L. K., S122

Oudemans, P., S27, S101

Oudemans, P. V., S94

Ouimette, D. G., S95

Owen, J., S142

Owens, A., S112

Owens, R., S95

Owens, R. A., S135

Ownley, B. H., 493, S2, S44, S45, S131

Oxalic acid

production by Postia placenta, S21

Sclerotinia sclerotiorum and, S58, S151, S160

Ozone gas

for control of postharvest decays of tomato, S33

response of Aspergillus flavus to sublethal level of, S138

p25 gene, Beet necrotic yellow vein virus and, breakdown of host resistance, 127

Padgett, G. B., S115, S153

Paecilomyces lilacinus, for control of nematodes and soil-borne disease in vegetable production, S50

Pagan, C., S113

Pahalawatta, V., S95

Pak choy. See Brassica rapa

Palenchar, J., S174

Palencia, E., S10

Palm, M., S168

Palmateer, A. J., S22, S104, S125, S174, S175

Palmer, C., S60

Palmer, J., S11

Palmero, D., S29, S39, S95

Palmero Llamas, D., S95

Palm-Hernandez, M. E., S175

Palms. See Phoenix spp.

Palou, L., S86

Palumbo, J. D., 532, S95

PAMDB (Plant-Associated Microbes Database), overview of, 208

Pan, Q., S96

Pan, R.-Q., S96

Pan, R.-W., S96

Panchal, S., S91

Pandelova, I., S160

Pandey, A. K., S96

Pandey, R., S67

Panella, L., 689

Panicum virgatum (switchgrass)

improvement of root, microbe, and soil interactions for enhanced value of, S40 
plant diseases in, S180

potential viral threats to in United States, S3 survey of diseases of in Tennessee, S131

Panstruga, R., S158

Pantocin A, for control of fire blight, S54

Pantoea spp.

$P$. agglomerans, on maize, $\mathrm{S} 119$

$P$. ananatis, on onion, $\mathrm{S} 144$

P. stewartii

on corn, S85, S188

type III secretion system of, S27, S184

$P$. vagans $\mathrm{C} 9-1$

complete genome sequence of, S120

for control of fire blight, 1330, S54, S59

Paolacci, A., 390

Papaya ringspot virus type W (PRSV-W), in

watermelon, 1194

Pappu, H., S122

Pappu, H. R., S1, S5, S10

Parasthrephia sp., influence of fallow soil period on, S41

Pardo, J. M., S5

Paret, M. L., S96

Park, B., 732, S97

Park, C., S198

Park, D., S146

Park, J., S25, S64, S96, S97

Park, P., 840

Park, S., S65, S77, S96, S97, S159, S164

Park, Y., S96

Parker, J. K., S29, S97

Parker, P. E., 1030, S15

Parker, S. R., S141

Parkunan, V., S97

Parnell, S., 638, 1030

Pasche, J. S., S135, S183

Pascual, A., 1315

Pascual, J. A., 682

Pasteuria usgae, for control of Belonalaimus

longicaudatus, S199

Pastor-Corrales, M. A., S98

Pataky, J. K., S98

Patel, N., S98

Pathogen detection lab-on-a-chip (PADLOC) system, development of, S76

Pathogenesis-related (PR) genes, resistance to rice

bacterial blight, D-allose and, 85

Paul, C., 756

Paul, P., S132, S137

Paul, P. A., 160, 784, 1015, 1066, S33, S65, S66,

S113, S184

Paulitz, T. C., 404, S85, S142

Paveley, N., 21

Paveley, N. D., S51

Payne, A. F., S98

Payne, G. A., S108, S138

Payne, S. A., 279

Paz, J. O., S92

Paz, Z., S64, S98

PCR (polymerase chain reaction) methods

assessing new biomaterials for sample collection and nucleic acid recovery in, S19

immunocapture RT-PCR for detection of viruses, S139

for sensitive detection of a panel of viruses, $\mathrm{S} 72$

for simultaneous detection of eight onion pathogens, S77

for simultaneous detection of four viroids, S72

Pe \pm a, G., S7, S29

Pe $\pm a$, J., S53

Pe \pm a-Reyes, E., S99

Pea. See Pisum sativum

Pea enation mosaic virus (PEMV), molecular characterization and ELISA-based detection of, S130

Peach. See Prunus persica

Peanut. See Arachis hypogaea

Pear. See Pyrus spp.
Pear blister canker (PBCVd), multiplex real-time RT-PCR assay for simultaneous detection of four viroids and, S72

Pecan. See Carya illinoinensis

Peckham, G. D., S66, S98

Pectobacterium spp.

biological traits of clades, S78

CorA transporter and virulence of, S61

effect of relative humidity on, $\mathrm{S} 31$

host-signaling responsive genes of, S3

on potato, detection and identification of, S70

Pedersen, J. F., S37, S185

Pedley, K., S190

Pedley, K. F., S61, S96

Peduto, F., S129

Peet, M. M., S109

Peever, T., S53

Peever, T. L., 120

Pegues, M. B., S46

Peiman Williams, M., S47

Peiris, K., S134

Pelargonium spp., viruses in, self- and crossinteraction studies among coat proteins and their domains, $\mathrm{S} 107$

Pelargonium zonate spot virus (PZSV), in tomato, vertical transmission of via seed and pollen, 798

Pelz-Stelinski, K. S., S172

Pena, A., S37

Peña, G., S7, S29

Peña, J., S53

Peña-Reyes, E., S99

Penbotec, for Penicillium expansum on pome fruit, S163

Peng, G., S99

Penicillium spp.

$P$. digitatum, fludioxonil and pyrimethanil and, natural resistance frequencies in, 738

P. expansum

on Anjou pear, 42

on apple, S63, S93, S163

benzimidazole for, $\mathrm{S} 163$

reduced sensitivity to pyrimethanil and fludioxonil, S2

P. solitum, on Anjou pear, polygalacturonase from, S58

Pennerman, K., S99

Penthiopyrad

for Ascochyta rabiei on chickpea, $\mathrm{S} 125$

for Didymella bryoniae, resistance against, S9

Pepino mosaic virus, detection and discrimination of different genotypes, S81

Pepper. See Capsicum annuum

Pepper golden mosaic virus (PepGMV), in pepper and tomato, viral DNA accumulation and, S50

Percich, J. A., S14

Perdomo, R. D., S4

Peres, N. A., S75, S86, S174

Perez, B. A., S21, S99

Perez, F. G., S52

Pérez, J., S40, S171

Pérez-Alfocea, F., 682

Pérez-Vega, E., 1315

Périnet, P., S196

Periodicity in host availability, evolutionary branching and, Gaeumannomyces graminis var. tritici, 1169

Periwinkle. See Catharanthus roseus

Perkins-Veazie, P., 33

Peronophythora litchii, resistance of against carboxylic acid amide fungicides, 522

Peronosclerospora sorghi, on sorghum, new virulent race of, $\mathrm{S} 106$

Peronospora spp.

P. belbahrii, on basil, S9, S107, S196, S198 on ornamentals, Orvego for control of, S60 on sweet basil, in Florida, S175

Peroxidase activity, and potato resistance against

Alternaria solani, for biochemical evaluation, 454
Perrot, G., 424

Perry, C. D., S202

Perry, K., S99, S100

Perry, K. L., S10, S147, S154

Persea borbonia (redbay), Raffaelea lauricola on,

1118, S177

Persea spp. (avocado), Raffaelea lauricola on, in Florida, S176

Perumal, R., S106

Pestalotiopsis guepini, on blueberry nursery plants, S99

Pestalotiopsis thea, on rambutan, in Mexico, S89

Peter, K., S100

Peters, R. D., S100

Peterson, G. L., S41

Peterson, N., S53

Peterson, P. D., 14, S100

Pfeufer, E. E., S100

PGPR, Bacillus spp. in potato rhizosphere as inoculant source, S20

Phaeomoniella chlamydospora, on grapevine, in Mexico, S87

Phaeosphaeria nodorum, sexual recombinants of and epidemics caused by, 855

Phakopsora pachyrhizi

germination of urediniospores, water vapor, liquid water and, S16

immunodiagnostic assays targeted to urediniospore wall proteins of, S75

on Jicama in U.S. and Florida beggerweed in Alabama, S29

kudzu resistance to, 941

on Medicago truncatula, S54, S129

on soybean

combinatorially selected peptides for protection against, 1111

effect of solar radiation on disease severity, S143

gene expression during appressorium formation by, S37

influence of environmental conditions on epidemic development, S128

protein profile differences between resistant and susceptible strains, S96

proteomics for identification of markers for resistance, $\mathrm{S} 164$

Rpp2 locus and resistance, $\mathrm{S} 96$

screening for resistant lines, S61, S203

sentinel plots in Florida, S178, S204

Simplicillium lanosoniveum for control of, S134

transcriptome analysis of interactions, S127

virulence and genetic diversity in Nigeria, S190

on soybean in Minnesota, five years of monitoring, S66

urediniospore detection, S131

urediniospore recovery, DNA extraction and, S185

weather patterns and distribution of in U.S., S92

Phalaenopsis orchids

Capsicum chlorosis virus from, S146

Sclerotium rolfsii and Dickeya sp. from, S22

Phaseolus spp. (bean)

P. lunatus (lima bean), Phytophthora phaseoli on, S66, S207

soybean cyst nematode on, $\mathrm{S} 102$

P. vulgaris

Beet curly top virus in, 972

Cucurbit leaf crumple virus in, in Georgia, S68

evaluation of germplasm for virus resistance, S99

Fusarium acuminatum and Fusarium redolens on, $\mathrm{S} 185$

Macrophomina phaseolina on, S23

Pythium spp. on, 1315, S48, S207 
Uromyces appendiculatus on, S98

Xanthomonas axonopodis pv. phaseoli on, S185

Phellinus sulphurascens, on Douglas fir seedlings, chitinase genes from, 356

Phenol production, and potato resistance against Alternaria solani, 454

PHEP (Phakopsora extracellular protein), of

Phakopsora pachyrhizi, S75

Pheromones, and Gibberella zeae on wheat, S43

Phialophora spp.

and Gaeumannomyces graminis var. tritici, reduction in severity of take-all disease, 404

$P$. gregata, on soybean, S79, S186, S188

Phillips, D., S35, S182

Phillips, D. V., S145

Phillips, N. A., S1

Phipps, P. M., S100, S153

Phoenix spp. (palms)

Marchites sorpresiva and M. lenta on, in Peru, S125

phytoplasma and dieback in, in Puerto Rico, S110

Texas phoenix palm decline in, Candidatus

Phytoplasma palmae-related strain and, S175

Phoma terrestris, on onion, fungicide dip

treatments for, S113

Phomopsis spp.

P. longicolla, on soybean, S26, S70, S148

$P$. viticola, on grape, S6

Phosphonate, for Phytophthora ramorum on tanoak, S115

Phosphoric acid

from fungicides and fertilizers, phytotoxicity to blueberry and grapes, S16

and Phytophthora palmivora on betel nut, $\mathrm{S} 178$

Photography, art, science and, S206

Photoreceptors, and R-protein mediated resistance

to Turnip crinkle virus, S56

Phymatotrichopsis omnivora

on cotton, flutriafol for control of, S54

PCR detection of, S7

Physalis peruviana (cape gooseberry)

and biological control, S13

Fusarium oxysporum on, S129

Phytophthora infestans on, S7, S29

Physalospora vaccinii, on cranberry, S101

Phytoalexin, UV-C induced disease resistance in carrots and, S65

Phytophthora spp.

P. alni, on alder, 1262

ametoctradin and dimethomorph for control of, $\mathrm{S} 90$

aquatic habitats as reservoir for, $\mathrm{S} 150$

$P$. aquatilis and $P$. aquimorbida, from irrigation reservoirs and natural waterways in Virginia, S51

P. asparagi, on asparagus, in Michigan, S176

P. cactorum, on Cattleya orchid liners from Thailand, S174

CANARY biosensors for rapid detection of, S73

P. capsici

abscisic acid-mediated predisposition to disease caused by, S104

on bottle gourd, $\mathrm{S} 65$

Brassica spp. short-cycle cover crops for management of, S190

on cucumber, S133

on cucurbits: baseline sensitivity to fluopicolide, S201; mustard cover crop for management of, S126; sensitivity to dimethomorph, cymoxanil, and mefenoxam, S195; variability in ability of isolates to cause disease, $\mathrm{S} 34$

diversity of from vegetable crops in Georgia, S55

essential oils for control of, S60 genetic diversity of, S41, S47

iprovalicarb for, 1162, S74

in New York state, mefenoxam resistance

and population structure, S20

on pepper, 774, S201

on squash, S142

on tomato, 619, Cover photo June

Zampro for control of, S57

chlamydospore and oospores in irrigation water, effect of temperature on survival of, S47

$P$. clandestina, and resistance, 551

P. cryptogea, from floriculture crops in North Carolina, phylogenetic history and genetic diversity, S94

on cucumber, effect of temperature, humidity and wounding, S43

database of, S150

detection in retail nurseries and urban forests in Nevada, S133

disease similar to root rot of, in Wisconsin, Rps $1 \mathrm{k}$ and, $\mathrm{S} 186$

diversity of in aquatic environments in

Maryland, S119

P. drechsleri

from floriculture crops in North Carolina, S94

on pistachio in Iran, S85

ecological adaptations of, forest ecosystems and, S151

$P$. erythroseptica, on potato, inheritance of mefenoxam resistance and, $\mathrm{S} 183$

$P$. infestans

on cape gooseberry, S7, S29

characterization based on mating type, metalaxyl sensitivity, and mtDNA haplotype, S121

dihydroorotase dehydrogenase from, S39

on diploid potato, $\mathrm{S} 87$

gene regulation during asexual development, S140

gene transcription patterns in, S94

Ic clade, $\mathrm{S} 68$

invasion of at landscape level, 1146

models predicting outbreaks of, S92

populations in China, genetic structure of as indication of multiple migration events, 997

on potato: in Colombia, S21; as crisis S161; genetic structure of populations in eastern North America 2002-2009, S52; intragenic technology for disease resistance, S101; MES1 gene and systemic acquired resistance, S77; molecular and morphological population characterization, S22; molecular interactions determining broad-spectrum partial resistance, $\mathrm{S} 46$

on tomato: BTH-mediated resistance, cysteine protease, acidic chitinase, PR1a and, S147; as crisis, S161; genetic structure of populations in eastern North America 2002-2009, S52; polyethylene mulch, greenhouse climate and, 97; response of resistant lines to Florida genotypes of, S29

P. kernoviae

in Ireland, S17

rapid detection of, 143

P. lateralis, on Port-Orford cedar, S167

multiplex assay for genus and species-specific

detection, $\mathrm{S} 14$

P. nicotianae

autoregulation of zoospore density-dependent behaviors, 632

from diverse hosts and geographic locations, S76

on spathiphyllum, S125

on tobacco, S97 in nurseries, greenhouses, and landscape plantings in Indiana, S69

$P$. palmivora, on betel nut, phosphoric acid application and, S178

P. phaseoli, on lima bean, S66, S207

P. pini, as valid and distinct species, S207

on pistachio in Iran, arbuscular vesicular

mycorrhizal colonization and, S85

$P$. ramorum

detection in soils by baiting and dilution plating, S208

field detection of within 30 minutes, S15

genotypic diversity of in Canada, S42

in Ireland, S17

migration pathway of, S157

rapid detection of, 143

screening Gulf Coast forest species for susceptibility to, S202

susceptibility of eastern Canadian tree species to, S197

susceptibility of eastern oak species to, S136

on tanoak, S115, S167

P. sojae

microsatellite markers for diversity assessment, S123

pathotype diversity of isolates from Iowa, S190

on soybean: calmodulin gene and resistance, S107; genes conferring partial resistance, S190; genetic variation in populations from Ohio and South Dakota, S191; mapping multiple novel resistance genes against, S192; modified method to screen for partial resistance, S123; multiplexed, probe-based quantitative PCR assay for, S48; Rps 8 gene and resistance, $\mathrm{S} 189$

taxonomic identification system based on microsatellites of, S29

on tomato and chrysanthemum, 871

value of morphological/phylogenetic key of exotypes and neotypes, S150

Phytoplasma

for cassava frogskin disease, $\mathrm{S} 5$

on juniper, S206

on Madagascar periwinkle, S127

strain differentiation using phylogenetic analysis of $\sec Y$ gene, S69

Phytopythium spp., taxonomy and nomenclature of, S150

Phytotoxins

of Burkholderia glumae, novel regulatory genes for, $\mathrm{S} 47$

thaxtomin A production, by Streptomyces scabies, suberin and cellobiose and, 91

Pi34 gene, and resistance against Magnaporthe oryzae, $\mathrm{S} 63$

Picea glauca, climate change and tree dieback and decline in Maine, S195

Pierce's disease. See Xylella fastidiosa

Pierrat, J.-C., 1262

Pierre, S. St., 80

Pierson, E. A., S159

Pierson, L. S., S159

Pieterse, C. M., S160

Pigm gene, rice blast and, broad-spectrum resistance, $\mathrm{S} 49$

Pik locus, in rice, and resistance against Magnaporthe oryzae, $\mathrm{S} 96$

Pilidiella granati, on pomegranate, in California, S83

Pine. See Pinus spp.

Pine wood nematode (PWN). See Bursaphelenchus xylophilus

Pineapple. See Ananas comosus

Pintye, A., S19

Pinus spp. (pine)

$P$. albicaulis (whitebark pine), forest restora- 
tion and, S166

blue stain fungi associated with decline of, in Lebanon, S111

cellular mechanisms that indicate needle health in seedlings, S203

P. contorta (lodgepole pine), Dothistroma septosporum on, S132

detection of the fungal pathogens causing brown spot and red band needle blights of PCR for, 105

P. monticola (western white pine), Cronartium ribicola on, $\mathrm{S} 120$

$P$. strobes (white pine), climate change and tree dieback and decline in Maine, S195

$P$. taeda (loblolly pine) cellular mechanisms that indicate needle health in seedlings, S203 death of epithelial cells in roots, $\mathrm{S} 131$

Pioli, R. N., 58

Pipo gene, of Soybean mosaic virus, S135

Pirahesh, S., S101

Pires, J., S42

Pistacia vera (pistachio), Phytophthora spp. on, in Iran, S85

Pisum sativum (pea)

Fusarium avenaceum and $F$. graminearum on, $\mathrm{S} 42$

Fusarium avenaceum on, in North Dakota, $\mathrm{S} 25$

Pityophthorus juglandis (walnut twig beetle), and Geosmithia morbida on walnut, status in California, S48

Pivato, B., 805

$\mathrm{Pi}-\mathrm{z}(\mathrm{t})$ gene, of Magnaporthe oryzae, characterization of, S202

Plamann, M., S80

Plant growth-promoting rhizobacteria (PGPR),

and Rhizoctonia solani on rice, $\mathrm{S} 170$

Plasmodiophora brassicae

on Brassica spp., S59

on canola, S99, S194

on pak choy, S74, S117

Plasmopara viticola, on grapevine, S136, S194

Plata-Caudillo, J. A., S101

Platz, G. J., 1298

Plectosporium tabacinum, on sweet basil in U.S., S32

Ploetz, R. C., 1176, S176, S177

Ploper, L. D., 58

Plum pox virus (PPV)

eradication of in Pennsylvania, S42

macroarray for strain differentiation, S117

in plum and peach, visual symptomatology, S209

Poa spp. (bluegrass)

$P$. апnиa (annual bluegrass) Colletotrichum cereale on, S109, S197 Xanthomonas translucens pv. poae on, $\mathrm{S} 23$

$P$. pratensis (Kentucky bluegrass)

Puccinia coronata on, S13 rust diseases of, S193

Podosphaera spp.

$P$. aphanis

cleistothecia of, initiation, development and survival of, 246 on strawberry, S8, S194

$P$. clandestina, cytb gene in, $\mathrm{S} 73$

P. macularis, on hop, S40, S138

P. xanthii

assessment of sensitivity to fungicides, S16

on cantaloupe and melon, S79

on cucurbits, $\mathrm{S} 40$

on pumpkin, S139

on watermelon with Cucurbita spp. rootstock, $\mathrm{S} 60$

Poinsettia, Botrytis cinerea on, S128

Pokharel, R., S101

Polashock, J., S27, S94, S101
Polizzotto, R., 390

Pollen, and transmission of Cucumber green

mottle mosaic virus, $\mathrm{S} 72$

Polyethylene mulch. See Mulch

Polygalacturonase

in Monilinia fructicola, regulation and functional characterization of, S25

from Penicillium solitum on Anjou pear, 42, S58

Polyketide synthase genes

Cercospora coffeicola on coffee and, S121

in Fusarium verticillioides, S18

Polynucleotide phosphorylase, regulation of

Dickeya dadantii type III secretion system by,

S144

Pome fruits, postharvest decays of, management

of fungicide resistance and, S163

Pomegranate. See Punica granatum

Ponciano, G. P., S101

Ponderosa pine, foliar chlorophyll content of on

black stain root rot disease sites, S94

Poojari, S., S101

Pooran DeSouza, S., S102

Popko, J. T., S92, S102, S197

Populus spp., Septoria musiva on, breeding for resistance, $\mathrm{S} 196$

Porchas, M., S79

Poromarto, S. H., S102

Porter, L., S25

Porter, L. D., S102

Post, A. R., S102

Postia placenta, effect of $\mathrm{pH}$ on genes involved in oxalic acid production, $\mathrm{S} 21$

Postnikova, O. A., S208

Potato. See Solanum phureja; Solanum tuberosum

Potato psyllid. See Bactericera cockerelli

Potato purple top (PPT) phytoplasma, in tomato, S135, S206, S207, S208

Potato spindle tuber viroid (PSTVd), in tomato,

effects on hormone signaling and, S95

Potato virus $S$, in potato germplasm, from South

America, S1

Potato virus $Y$

distribution and prevalence of strains in Iran, S87

isolate from PVYZ strain group, molecular make-up of, S61

resistance against in wild relatives of potato, S19

Potato witches'-broom (PWB) phytoplasma, in tomato, $\mathrm{S} 135$

Potato yellow dwarf virus (PYDV), protein

localization map for, S11

Potato yellow vein virus (PYVV), in Solanum

tuberosum and $S$. phureja, in Colombia, S176

Potnis, N., S36, S103

Potyviruses

CANARY biosensors for rapid detection of, S73

electrophoretic transformation into pepper protoplasts, $\mathrm{S} 130$

Poudel, B., S103, S128

Poultry litter, for control of Sclerotium rolfsii, S29, S103

Poverty, food security and, S156

Powell, C. A., 239, S145

Powell, G., S70

Powell, W. A., S10, S29, S89, S91

Prabavathy, V. R., S116

Prathuangwong, S., S8, S103

Prats, E., 21

Pratt, P. D., S108

Pratt, R., S103

Pratt, R. C., 72, S27, S184

Pratylenchus spp.

associated with bioenergy crops, S74

$P$. penetrans

on corn, S28, S184

on potato, $\mathrm{S} 180$
Pressure cycling technology, for extraction of $\mathrm{Ca}$.

Liberibacter spp., S114

Presting, G. G., S78

Pretorious, Z. A., S156

Preuett, J. A., S202

Prezelj, N., S81

Price, J. A., S103

Prinster, M., S108

Prior, P., 1250

Pritsch, C., S110, S118

Probability distributions, for disease severity and time-to-event data, S81

Proboscis extension reflex, of honeybee as biological sensor for Erysiphe necator, S124

Probst, C., S39, S103

PROCULTURE model, for septoria wheat leaf

blotch on winter wheat, S32

Prodi, A., 1100

Proffer, T. J., S69

Prom, L. K., S106

PROPEP1-7 (elicitor precursor genes), of rice, defense signaling, disease resistance and, S73

Propiconazole, for Sclerotinia homoeocarpa on turfgrass, S102

Propulse, for cylindrocladium black rot of peanut, S100

Prosser, S. W., S104

Protein kinases, of Fusarium graminearum, S151

Proteomics, for markers for developing broad spectrum resistance, $\mathrm{S} 164$

Prothallonema asymmetricum, in Iran, S83

Prothioconazole

for cylindrocladium black rot of peanut, S100

for Puccinia graminis f. sp. tritici on wheat, $\mathrm{S} 44$

PRSV-W. See Papaya ringspot virus type $W$

Prunus necrotic ringspot virus (PNRSV), on rose, chemo-thermotherapy for control of, S84

Prunus replant disease, of almond, microbial community shifts associated with, S115

Prunus spp.

P. avium (sweet cherry), Montmorency stem pitting virus in, $\mathrm{S} 130$

P. dulcis (almond) prunus replant disease of, S115 Xylella fastidiosa on, S24, S119

P. persica (nectarine) Geotrichum candidum on, S141

Xanthomonas arboricola pv. pruni on, S11

P. persica (peach)

brown rot on, $\mathrm{S} 195$

Geotrichum candidum on, S141

Monilinia fructicola and M. laxa on, S119

Xanthomonas arboricola pv. pruni on, S11

Plum pox potyvirus in, $\mathrm{S} 209$

Pryor, B. M., S5

Pseudocercospora fuligena, on tomato, in

Thailand, S82

Pseudomonas spp.

P. cannabina pv. alisalensis, in irrigation water, S79

$P$. chlororaphis $\mathrm{O6}$, induced systemic resistance and, S158

for control of Gaeumannomyces graminis var. tritici on wheat, S141

$P$. fluorescens A506, for control of fire blight, 1330

inhibition of Aspergillus flavus by, 532

$P$. putida, S1Pf1Rif from, against chrysanthemum yellows phytoplasma (CYP) infection of daisy, 805

$P$. savastanoi, on mandevilla, genome sequence and comparative genomics of, $\mathrm{S} 104$

$P$. solanacearum, on tomato, biological control of, S34

on sorghum, effect of genotype, S37

$P$. syringae

on Arabidopsis, stomate-based defense against, S24 
coronatine and, S54, S160

extracytoplasmic function (ECF) sigma (s)

factors in, S12

global gene expression analysis of during

epiphytic and endophytic growth, S136

PAMDB and, 208

on potato, $\mathrm{S} 23$

on soybean, S106, S117

Pseudoperonospora spp.

P. cubensis

on cantaloupe, S202

on cucumber, 97

on cucurbits, 1066, S43

effect of temperature and wetness duration on sporulation rate of, $\mathrm{S} 89$

quantitative models for germination and infection of, 959

relationship to Pseudoperonospora humuli, S84

P. humuli, relationship to Pseudoperonospora cubensis, $\mathrm{S} 84$

on ornamentals, Orvego for control of, S60

Pseudotsuga menziesii (Douglas fir)

Phellinus sulphurascens on, 356

resistance to rhabdocline needlecast, 337 , Cover photo April

Pseudozyma flocculosa, for powdery mildews, mechanism of action, $\mathrm{S} 198$

PthA gene, and Xanthomonas axonopodis pv. citri on grapefruit, $\mathrm{S} 71$

Puccinia spp.

$P$. arachidis, on peanut, control of with

fungicides in Nicaragua, S8

$P$. coronata

on Avena barbata in Canada, S21

on Kentucky bluegrass, S13

on oat, and resistance, QTL for, 484, 511

P. emaculata, on Medicago truncatula, non-

host resistance mechanisms of, S129

P. graminis

on barley, S157

identification and monitoring of highly virulent race of, $\mathrm{S} 156$ on wheat, S44, S93

$P$. hemeroca, on daylily, effect of light on, S31

$P$. hordei, on barley, in Iraq, $\mathrm{S} 4$

P. kuehnii, on sugarcane, S78, S106, S173, S175

P. melanocephala, on sugarcane, effect of crop and environmental variables on, S12

new and re-emerging, in Idaho and Oregon,

S113

P. pelargonii-zonalis, on geranium, S31, S116

$P$. polysora

on corn, real-time PCR for detection of, S27

sources of Rpp-resistance to an Rppvirulent isolate of, S98

P. psidii

on Eugenia koolauensis, S128

on Melaleuca quinquenervia, S108

P. striiformis

Berberis spp. as alternate host for, 432, Cover photo May

races identified in U.S. in 2009, S132

on Trititrigia Zhong 4, S133

on wheat, 313, S53, S132

P. triticina

forecasting of, S32

genetic differentiation within populations of, 376

Pucciniastrum spp.

on blueberry nursery plants, S99

on hydrangea, S71

Puckett, R., S83

Pueraria spp. (kudzu)

first virus infecting in U.S., S112

Phakopsora pachyrhizi on, 941
Pumpkin. See Cucurbita spp.

Punica granatum (pomegranate)

Botrytis cinerea on, S86

Pilidiella granati on, S83

Puppala, N., S114

Puri, K., S4

Puri, K. D., 1007, S104, S189

Purvis, M., S57, S142

Purwar, S., S104

Putnam, M. L., S104, S206

PWN. See Bursaphelenchus xylophilus (pine wood rot nematode)

PWT1 avirulence allele, of Magnaporthe oryzae,

recognition by wheat and barley, 436

Pye, M. F., 871, S104

Pyraclostrobin

for Botrytis cinerea on apple, S63, S143

for Cercospora sojina on soybean, S145

for Fusarium graminearum, S147

for Penicillium expansum on apple, S63

Pyrenophora spp.

P. teres

on barley, $80, \mathrm{~S} 68$

MAT loci for differentiation of, 1298

$P$. tritici-repentis, on wheat

genetic diversity of mating type and toxin production genes, 474

host-selective toxins and, S160

QTL for resistance against, 460

resistance against, $\mathrm{S} 45$

Pyricularia oryzae, on rice, in Arkansas,

genotypic and phenotypic diversity of, S145

Pyrimethanil, against Penicillium spp.

natural resistance frequencies, 738

reduced sensitivity to, $\mathrm{S} 2$

Pyrus spp. (pear)

Alternaria alternata on, reactive oxygen species generation and penetration of appresoria, 840

P. communis (Anjou pear), Penicillium spp. on, 42 , S58

P. pyrifolia (Japanese pear), Alternaria alternata on, 840

Pythiogeton spp., taxonomy and nomenclature of, S150

Pythium spp.

P. abappressorium, $\mathrm{S} 134$

$P$. aphanidermatum, $\mathrm{S} 36, \mathrm{~S} 48$

on corn, in Ohio, S33

on cotton, $\mathrm{S} 153$

diversity assessment in forest nurseries, S153

DNA barcode, genomics, and phylogenetics of, S153

ecology and biology of, S152

$P$. irregulare

population genetics and inter-species boundaries, $\mathrm{S} 154$

on soybean, $\mathrm{S} 33$

range of aggressiveness of species associated with plants, S153

sampling and sample processing, S153

sensitive molecular detection of, S7

on snap bean, S207

on soybean, S33, S111, S184

taxonomy and nomenclature of, S150

on tomato, S73

P. ultimum

after nutrient impulse in soils, 593

on bean, 1315

on corn, $\mathrm{S} 28$

metalaxyl for, S102

transmission of in fungus gnats, 1307

Trichoderma harzianum for control of, 1213

PZSV. See Pelargonium zonate spot virus

Qi, M., S104

Qin, H., S105

Qiu, J., S105
Qiu, W., S38

Qu, B., 183

Qu, F., S105

Quarantine, and pest risk analysis, role of in food security, S156

Quello, K. L., S183, S189

Quercus spp. (oaks)

Ceratocystis fagacearum on, 979

Phytophthora ramorum on, S15, S136, S167

Raffaelea quercivora on, 747

Quesada-Ocampo, L. M., 619

Quito, D., S106

Quorum quenching, and Burkholderia glumae on rice, S96

Quorum sensing, Acidovorax avenae and, S148

$R$ genes, Pseudomonas syringae on soybean and, S106

Rabenoelina, F., 424

Radwan, G. L., S106

Radwan, O., S106

Raffaelea spp.

R. lauricola

on avocado, $\mathrm{S} 176$

and redbay ambrosia beetle, 1118

on redbay and other species, S177

R. quercivora, on Quercus spp., 747

Rahman, A., S106

Rahman, M., S21, S106

Rahman, M. H., S130

Raid, R. N., S36, S78, S106, S107, S175, S196

Raikhy, G., S107

Rajashekara, G., S13, S140

Rakhshandehroo, F., S4, S31, S84, S87

Ralstonia solanacearum

CANARY biosensors for rapid detection of, S73

on ginger, screening for biological control agents for, $\mathrm{S} 141$

PAMDB and, 208

on potato, phenotypic diversity of strains, 1250

race 3 biovar 2

DNA-based diagnostics for detection of, S66

education and outreach program for best management of, S22

effective international education program for management of, S173

novel detection using magnetic capture hybridization and real-time PCR, S45

temperature fluctuations and viability reduction, $\mathrm{S} 115$

on tobacco, S14, S100

on tomato, S15, S55, S88, S109

type III secretion system of, S55

Ramadugu, C., S46, S77, S107

Raman spectroscopy, for identification of

Xanthomonas spp., S96

Rambutan. See Nephelium lappaceum

Ramirez, A. L., S110

Ramírez, C., S170, S171

Ramírez, M., S171

Ramos, A. T., S21

Randoux, B., 1352

Rao, S., S107

Raper, R. L., S16

Rapeseed. See Brassica napus

Rapid Cycling Brassica Collection (RCBC),

Plasmodiophora brassicae on, S59

Rappaport, K., S73

Rascon, A., S62

Rascon, A. A., S107

Rasmussen, J., S151

Rasmussen, J. B., S185

Raspberry latent virus, and new genus of dicot

infecting reoviruses, $\mathrm{S} 106$

Rathburn, H. B., S88

Ratoon stunting disease, of sugarcane, S21 
Rauscher, G., S107, S108

Rav David, D., 225, S33

Ravanlou, A., S108

Ravnikar, M., S81

Rayamajhi, M. B., S108

Rayapati, N. A., S90

RcsC sensor kinase, of Erwinia amylovora, comparative analysis vs. other enterobacteria, S133

Reactive oxygen species

Alternaria alternata in Japanese pear and, 840

Botyrtis cinerea and, S151

coronatine from Pseudomonas syringae pv. tomato and, S54

FvNoxR gene of Fusarium verticillioides and, $\mathrm{S} 44$

Mycosphaerella graminicola pathogenicity and, S25

opine wood nematode and, 1289

Sclerotinia sclerotiorum, S58

Trichoderma harzianum seed treatment and, 1213

Rebello, G., S108

Rebollar-Alviter, A., S6

Recknor, J., S58

Records, A. R., S136

Red flour beetles. See Tribolium castaneum

Redbay. See Persea borbonia

Redbay ambrosia beetle. See Xyleborus glabratus

Redbud yellow ringspot-associated virus

(RYRSaV), S67, S201

Reddy, M., S65, S146

Reddy, M. S., S170

Redinbaugh, M., S105

Redinbaugh, M. G., 1138, S27, S184

Reed, A., 493

Reed, S., S71

Reese, B. N., S108, S138

Reeves, P. A., S164

Rehman, M., S172

Reignault, P., 1352

Reiners, S., S20

Remote sensing applications for plant pathology using latex weather balloons, S188

Rémus-Borel, W., S196

Ren, H., 573

Renard, M.-E., 474

Renard-Merlier, D., 1352

Replicase proteins, of Grapevine rupestris stem pitting-associated virus, $\mathrm{S} 104$

Replogle, A., S108

Repshare, J. M., S115, S116

Rer (resistance to rust) mutants, Phakopsora pachyrhizi on Medicago trunculata and, S54

Resistance

against Alternaria solani, of potato, biochemical evaluation of, 454

of Alternaria spp., against fungicides, S14, S55, S130

of annual bluegrass, against Xanthomonas translucens pv. poae, systemic acquired resistance and, S23

against Aspergillus flavus, of corn, S4, S37

of barley

against Blumeria graminis f. sp. hordei, $\mathrm{S} 158$

against Cochliobolus sativus, $\mathrm{S} 110$

against Puccinia graminis f. sp. tritici, S157

against septoria speckled leaf blotch and net form net blotch, 80

of bean

evaluation of germplasm for virus resistance, S99

against Pythium ultimum, 1315

against Sclerotinia sclerotiorum, S122

against Uromyces appendiculatus, $\mathrm{S} 98$

against Beet necrotic yellow vein virus

and host effect on genetic diversification

of single-plant populations, 1204 of sugar beet, 127, S2, S120

viral evolution for overcoming, S149

against benzimidazole, of Botyrtis cinerea S62

against Bipolaris oryzae, of rice, mapping genes for resistance to, $\mathrm{S} 11$

of blueberry, against Colletotrichum spp., screening for resistant lines, S83

against Blumeria graminis f. sp. hordei, of barley, molecular basis of broad-spectrum resistance, $\mathrm{S} 158$

against boscalid, of Didymella bryoniae, S201

against Botrytis cinerea, and IVR gene, 225, 400

of Botrytis cinerea

against benzimidazole, $\mathrm{S} 62$

against fungicides, S63, S134, S143

of Brassica spp., against Leptosphaeria maculans, screening for resistant lines, S77

broad-spectrum

against oomycetes and fungi, conserved effectors and effector motifs for, $\mathrm{S} 158$ against Phytophthora infestans on potato, S46

using oligoadenylate system, S38

of canola, recombinant antibody-mediated multiple disease tolerance, S130

against carboxylic acid amide fungicides, of

Peronophythora litchii, 522

against Cercospora arachidicola, of peanut, S200

of Cercospora arachidicola, against fungicides, S105

against Cercospora sojina, of soybean, $\mathrm{S} 28$

of chestnut, against Cryphonectria parasitica, S10

against Cochliobolus spp.

of barley, S110

of maize, S114

against Colletotrichum spp., of blueberry, rapid screening for resistant lines, S83

against copper, of Xanthomonas citri subsp. citri, S13, S172

of corn

against Aspergillus spp., S4, S37

against Cochliobolus heterostrophus, S114

against foliar diseases, mapping quanti-

tative trait loci for, 72

against Maize streak virus, $\mathrm{S} 113$

against Stenocarpella maydis, S88

against Cronartium ribicola, of Pinus

monticola, S120

against Cryphonectria parasitica, of chestnut, S10

against Cucumber mosaic virus, of Gladiolus spp., S59

of cucurbits (wild), against Meloidogyne incognita, $\mathrm{S} 35$

cuticle in basal and induced defense against bacterial and fungal pathogens, S139

of Didymella bryoniae

against boscalid, S201

against fungicides, S9, S126

against dodine, of Venturia inaequalis on apple, S27

of Douglas fir variety Shuswap, to rhabdocline needlecase, 337

against Elsinoë fawcetti, of grapefruit, S86

of Erysiphe necator, against fungicides, S9

evaluation of world collections of wheat for, S65

against fludioxonil and pyrimethanil, of Penicillium digitatum, natural frequencies of, 738

against fungicides

of Alternaria spp., S14, S55, S130

of Botrytis cinerea, S63, S134, S143

of Cercospora arachidicola, S105

of Didymella bryoniae, S9, S126 of Erysiphe necator, S9

of Fusarium graminearum, S147

model to predict selection for resistance,

S5

mutations in succinate-dehydrogenase in-

hibitor target protein and, S37

of Penicillium expansum, S163

of Phytophthora spp., S74, S147, S183

of Podosphaera spp., S73, S139

postharvest, mechanisms of, S162, S163

and postharvest decays of pome fruits, S163

of Pythium ultimum, $\mathrm{S} 102$

ShCYP51 gene of Sclerotinia homoeocarpa and, S75

of Venturia inaequalis, S23, S69, S100, S189

of Fusarium graminearum, against fungicides,

S147

against Fusarium spp.

$F$. graminearum: of soybean, S33; of wheat, S50, S104, S186

F. oxysporum, of watermelon, S99

F. solani, of pea, S45

of sorghum, alteration of lignin biosynthesis and, 671

of Gladiolus spp., against Cucumber mosaic virus, S59

of grapefruit, against Elsinoë fawcetti, S86

$H$ gene and resistance to Hessian fly, 279

against Hessian fly, $H$ gene and, 279

against Heterodera glycines, of soybean, rhg 1

locus and, S26

of hop, against Podosphaera macularis, S138

of hydrangea, against Pucciniastrum hydrangeae, $\mathrm{S} 71$

against iprovalicarb, of Phytophthora capsici, 1162

of kudzu against Phakopsora pachyrhizi, 941

against Leptosphaeria maculans, of Brassica spp., S77

against Magnaporthe oryzae

Pi34 gene and, S63

Pigm gene and, S49

Pik locus and, S96

QTL in Japonica rice landrace responsible for, 822

against Maize streak virus, of maize, S113

against mefenoxam, of Phytophthora capsici in New York state, S20

against Meloidogyne incognita, of wild cucurbits, S35

and modification of maize chitinase of by Stenocarpella maydis, 645

of Monilinia spp., against fungicides, S50

against Mycosphaerella fijiensis m., on banana and plantain, S5

pattern recognition receptors in plant innate immunity, S157

of pea against Fusarium solani f. sp. phaseoli, S45

of peanut

against Cercospora arachidicola, S200 against Tomato spotted wilt virus, S105

of Penicillium spp.

against fludioxonil and pyrimethanil, natural frequencies of, 738 against fungicides, S163

of Peronophythora litchii, against carboxylic acid amide fungicides, 522

against Phakopsora pachyrhizi

of kudzu, 941

of soybean, S61, S96, S129

against Phomopsis longicolla, of soybean, S70 against Phytophthora spp.

P. capsici: compost water extracts for, 774; of tomato, in domestic and wild relatives, 619, Cover photo June

P. clandestina, of subterranean clover, 551 
P. infestans: broad-spectrum partial, $\mathrm{S} 46$ effects of spatial scale and weather, 1146; of potato, S46, S77, S87, S101; of tomato, S29

$P$. sojae, of soybean: calmodulin gene and, S107; mapping multiple novel resistance genes against, S192; modified method to screen for partial resistance, $\mathrm{S} 123 ;$ Rps 8 gene and, S189

of Phytophthora spp. against fungicides

P. capsici, 1162, S20, S74

P. erythroseptica, $\mathrm{S} 183$

P. infestans, $\mathrm{S} 147$

of Pinus monticola, against Cronartium ribicola, $\mathrm{S} 120$

of plantain and banana, against $\mathrm{Myco}$ sphaerella fijiensis $\mathrm{m}$. on, S5

against Podosphaera spp.

$P$. aphanis, of strawberry, $\mathrm{S} 8$

P. macularis, of hop, $\mathrm{S} 138$

of Podosphaera spp. against fungicides

P. clandestina, $\mathrm{S} 73$

P. xanthii, $\mathrm{S} 139$

of Populus spp., against Septoria musiva, S196

of potato

against Alternaria solani, biochemical evaluation of, 454

against Phytophthora infestans, S46, S77, $\mathrm{S} 87, \mathrm{~S} 101$

against potato virus $Y$ in wild relatives of potato, S19

proteomics for identification of markers for, S164

against Pseudomonas syringae, of soybean,

RPG1-B and, S117

against Puccinia spp.

P. coronata: broad-spectrum resistance sources, S21; of wheat, QTL in Ogle/TAM O-301 mapping population, 484

P. emaculata, of soybean, $\mathrm{S} 129$

$P$. graminis f. sp. tritici, of barley, S157

P. polysora, Rpp genes and, $\mathrm{S} 98$

against Pucciniastrum hydrangeae, of

hydrangea, S71

against Pyrenophora tritici-repentis, of wheat, 460, S45

against pyrimethanil and fludioxonil, of

Penicillium expansum, S2

against Pythium spp.

of bean, mapping QTL for, 1315

of soybean, $\mathrm{S} 184$

of Pythium ultimum, against metalaxyl, S102

against QoI fungicides, of Alternaria solani, S55

QTL for genes that contribute to, S157, S164

of rapeseed, against Sclerotinia sclerotiorum, S18

against rhabdocline needlecase, 337

against Rhizoctonia solani

of rice, S136, S146

of St. Augustine grass, S36

of Rhynchosporium secalis on barley, against

triazole, S49

of rice

against Bipolaris oryzae, $\mathrm{S} 11$

against Magnaporthe oryzae, S49, S74, S96

against Rhizoctonia solani, S136, S146

against rice bacterial blight, D-allose and, 85

saccharine and induction of systemic acquired

in soybean, $\mathrm{S} 122$

of Sclerotinia homoeocarpa, against fungi-

cides, S75

against Sclerotinia sclerotiorum

of bean, $\mathrm{S} 122$

of rapeseed, $\mathrm{S} 18$

against Septoria musiva, of Populus spp., breeding for, S196

against septoria speckled leaf blotch and net

form net blotch, of barley, 80

of sorghum, against Fusarium spp., 671

of soybean

against Cercospora sojina, S28

against Fusarium graminearum and

Pythium irregulare, S33

against Phakopsora pachyrhizi, S61, S96,

S129

against Phomopsis longicolla, S70

against Phytophthora sojae, S107, S123,

S189, S192

against Pseudomonas syringae, $\mathrm{S} 117$

against Pythium spp., S184

saccharine and induction of systemic acquired, S122

against soybean cyst nematodes, S26, S58, S190

against soybean cyst nematodes, of soybean,

S26, S58, S190

of St. Augustine grass, against Rhizoctonia solani, S36

against Stenocarpella maydis, chiA genes as marker for, $\mathrm{S} 88$

of strawberry, against Podosphaera aphanis, S8

against stripe rust, of wheat, 313

of subterranean clover, against Phytophthora clandestina, 551

of sugar beet, against Beet necrotic yellow vein virus, $127, \mathrm{~S} 2, \mathrm{~S} 120$

systemic, and biochar, 913

against tebuconazole,

Cercospora

arachidicola on peanut, $\mathrm{S} 105$

of tomato

against Phytophthora capsici, 619, Cover photo June

against Phytophthora infestans, S29

against Tomato chlorosis virus, 582

against Tomato chlorosis virus, of tomato, 582

against Tomato spotted wilt virus, of peanut,

S105

against triazole, of Rhynchosporium secalis on

barley, S49

in turfgrass against diseases, fifty years of breeding for, $\mathrm{S} 193$

to Turnip crinkle virus, HRT protein and photoreceptors, S56

against Uromyces appendiculatus, of bean, S98

$\mathrm{UV}-\mathrm{C}$ induced disease resistance in carrots, S65

of Venturia inaequalis, against fungicides,

S23, S27, S69, S189

of watermelon, against Fusarium oxysporum $\mathrm{f}$. sp. niveum, $\mathrm{S} 99$

of wheat

against Fusarium graminearum, S50, S104, S186

pathogen hijacking of mechanisms, S151

against Puccinia coronata, 484

against Pyrenophora tritici-repentis, 460, S45

against stripe rust, 313

against Xanthomonas campestris, S59

against Xanthomonas translucens, S3

against Xanthomonas anxonopodis, of

calamondin and kumquat, S24

against Xanthomonas campestris, of wheat, S59

against Xanthomonas citri subsp. citri, S37, S42

of Xanthomonas citri subsp. citri, against copper, S13, S172

against Xanthomonas translucens, S3, S23

Restom Gaskill, D. A., S175

Restrepo, S., S7, S8, S19, S21, S22, S29, S39,

S86, S127, S129
Restriction-associated DNA (RAD) tags, for Colletotrichum spp., S27

Revus, for Bremia lactucae on lettuce, S66

Reyes Gaige, A., S118

Reynaldi, S., S40

Reynolds, K., S74

Reynoutria sachalinensis, Regalia from, for control of cucumber powdery mildew and lettuce downy mildew, S123

Rezaee, S., S13, S83, S101

Rezende, J. A., S87

Rezzonico, F., S120

RFP (red fluorescent proteins), in Ophiosphaerella herpotricha on bermudagrass, 415

Rhabdocline oblonga and $R$. oblonga, on Douglas

fir variety Shuswap, 337, Cover photo April

Rhg genes, and resistance against soybean cyst nematodes, S26, S58

Rhizoctonia spp.

biology and management of similar diseases in turfgrass, S152

on cereal crops, S85

$R$. fragariae, on strawberry, S195

isolation of from soil, evaluation of selective media and chemicals for, S121 on lettuce, $\mathrm{S} 13$

$R$. oryzae, on bermudagrass, $\mathrm{S} 152$

$R$. oryzae-sativae, on rice, 493

R. solani

anastomosis group 3, S32

Bacillus subtilis MBI 600 for control of, S65

on canola, S89

ITS-RFLP for identification of, S113

on maize, $\mathrm{S} 4$

on miscanthus, $\mathrm{S} 17$

on rice: in Arkansas, multilocus analysis, $\mathrm{S} 22$; ethylene and abscisic acid in mediating resistance against, S146; OsPROPEP1-7 (elicitor precursor genes) and, S73; phenotyping the components of resistance, S136; plant growthpromoting rhizobacteria and, S170; screening for bacterial antagonists, S146; suppression of by cow urine, S56

on rice and maize, divergence among populations infecting, 172

on St. Augustine grass, screening for resistance, S36

on sugar beet: AG 2-2 isolate, aggressiveness of, S16; Azoxystrobin for, S102; cultivar selection for resistance, S123; in Michigan, S47; in Nebraska, azoxystrobin for management of, S48; temperature, moisture, and fungicide effects in managing, 689, Cover photo July

on tall fescue, S80, S205

on tomato, 493

on wheat, S142

on zoysiagrass, S91, S203

on tall fescue, S28, S80, S205

on turfgrass in Maryland and Virginia, S6

$R$. zeae, on bermudagrass, $\mathrm{S} 152$

Rhizopus stolonifer, on tomato, S33

Rhododendron spp., Phytophthora spp. on, in Ireland, S17

Rhynchosporium secalis, on barley, S49

Ribes missouriense, Cronartium ribicola on, 986

Rice. See Oryza sativa

Rice, J. T., 404

Rice, K. A., S88

Rice blast. See Magnaporthe oryzae

Richard, J., S108

Richardson, K., S108

Richardson, P., S51, S207

Richwine, N., S42

Ridenour, J. B., S109

Rideout, S. L., S48, S207 
Ridout, C. J., S157

Riegel, D. G., S136

Riley, D. G., S122

Riley, R. T., S147

Riley, T., S172

Rinehart, T., S71

Rinehart, T. A., S45

Rines, H. W., 511

Rintoul, T. L., S153

Rioux, D., S197

Rioux, S., S193

Risede, J., S58

Risk assessment, role of in food security, S156

Ristaino, J. B., 997, S52, S68, S161

Ritenour, M. A., S12

Ritson, R., S182

Rivard, C., S73

Rivard, C. L., S109

Rivera, L. I., S176

Rivera, M. C., S21

Rivera-Varas, V. V., 290

Rizzo, D., S167

Rizzo, D. M., 871

Roane, C. W., S206

Robbins, R. T., S114

Roberts, J. A., S109, S197

Roberts, M., S162

Roberts, P., S52

Roberts, P. C., 21

Roberts, P. D., S52, S175

Robertson, A., S183

Robertson, A. E., 931, S14, S109, S123, S182, S190

Robertson, C. L., S134, S203

Robertson, J., S59

Robertson, N. L., S109

Robideau, G. P., S150, S153

Roca, M., S99

Roca, M. M., S176

Rocateli, A. C., S16

Rockhold, D. R., S101

Rodrigues, J. V., S110

Rodriguez, S., S110, S118

Rodríguez-Alvarado, G., 1176

Rodriguez-Burgos, P., S176

Rodriguez-R, L. M., S8

Rodriguez-Salamanca, L., S176

Roenhorst, A., S81

Rogers, C. A., S208

Rogers, E. E., S68, S110

Rogers, S., S110

Rogers, S. L., S12, S35

Rohfritsch, O., 279

Roig, J., S41

Rojas, P. F., S110

Rojas-Bertini, C., S110

Roldán, A., 682

Rollins, J., S151

Rollins, J. A., S201

Roman, F., S34

Romer, P., S36

Rommens, C. M., S101

Rong, X., S159

Roose, M., S107

Root-knot nematodes. See Meloidogyne incognita

Roper, C. M., S85

Rosa spp.

Arabis mosaic virus and Prunus necrotic ringspot virus in, $\mathrm{S} 84$

Botrytis cinerea on, $\mathrm{S} 62$

Xanthomonas sp. on, S129, S177

Rosales Villavicencio, I., S99, S110

Rose rosette-associated virus (RRaV), S67

Rosellinia necatrix, mycoviruses from, 922

Rosenberger, D. A., 345, S197

Ross, D., S51

Ross, R. E., S18, S205

Ross, S., S208

Rossard, S., 1352
Rossi, L., S166

Rossi, V., 1321, S19, S194

Rossing, W. A. H., 1146

Rosskopf, E., S176

Rosskopf, E. N., S19

Rostagno, L., 1100

Rothrock, C., S31, S75, S111, S129

Rothrock, C. S., S121, S153, S203

Rothwell, N. L., S9

Rott, P. C., S111

Rotylenchulus reniformis

on cotton, nematicides for management of, S86

detection by conventional and real-time PCR, S114

Roubtsova, T. V., 871, S104

Rough lemon. See Citrus jambhiri

Rouse, D. I., 986

Rouxel, T., S158

Rowhani, A., 830, S3, S5

Roy, A., 1077, S111

Roy-Chowdhury, M., S202

Royer, M., S111

Rpf genes

and Xanthomonas axonopodis pv. glycines on soybean, $\mathrm{S} 103$

and Xanthomonas oryzae pv. oryzae virulence, S25

RPG1-B, and Pseudomonas syringae on soybean, S117

rpoN and, and Brenneria rubrifaciens on walnut, $\mathrm{S} 80$

Rpp genes

Phakopsora pachyrhizi on soybean, S61, S96 resistance against Puccinia polysora and, $\mathrm{S} 98$

Rps genes

and Phytophthora sojae on soybean, S189 and Phytophthora-like root rot, S186

RT-PCR. See PCR methods

Ruaro, L., S111

Rubus occidentalis (black raspberry), Black raspberry necrosis virus in, S56

Rudolph, K., S111

Rugh, A. L., S197

Ruhl, G., S69

Ruhl, G. E., S168

Ruhl, G. S., S32

Rumohra adiantiformis (leatherleaf fern), fern

distortion syndrome on, S63, S170

Rupe, J., S26, S31, S111, S129

Rupe, J. C., S70, S203

Rush, C., S50, S68

Rush, C. M., 127, 1204, S2, S103, S120, S138, S149, S203

Russell, P., S15

Russell, S. A., S136

Russell, T., S131

Russo, J., S46, S179

Russo, V. M., 33

Ryegrass, perennial. See Lolium perenne

Ryegrass bunt, and Tilletia spp., 645

Rynchosia minima, bean-infecting begomovirus from, $\mathrm{S} 172$

Ryu, C., S54, S160

$R z 2$ gene, and Beet necrotic yellow vein virus in sugar beet, S120

S1Pf1Rif, from Pseudomonas putida, 805

Saad, A. T., S111

Saalau Rojas, E., S26, S112, S189

Sabanadzovic, S., S2, S103, S112, S123

Saberi-Riseh, R., S84

Saborío, F., S63

Saccharin, and induction of systemic acquired resistance in soybean, $\mathrm{S} 122$

Saccharrum spp. (sugarcane)

Leifsonia xyli subsp. xyli on, S21

Puccinia kuehnii on, S78, S106, S173, S175

Puccinia melanocephala on, S12

Sugarcane streak mosaic virus in, S140
Sugarcane yellow leaf virus in, S43

Xanthomonas albilineans on, S39, S78

Safety

and biotechnology regulation, $\mathrm{S} 176$

food security and, S156

fresh produce and, S155

human pathogens on plants and, S168

Salmonella outbreaks associated with vegetables and, S177

Saffarian Abbas Zadeh, M., S113

Saha, S., S72

Sahebani, N., 454

Sainju, U. M., S68

St. Augustine grass. See Stenotaphrum secundatum

Sakthikumar, S., S156

Salama, N., 814

Salas, G., 58

Salaudeen, M. T., S113

Salazar, J. J., S4

Salgado, J. D., S113

Salicylate hydroxylase, of Candidatus Liberibacter asiaticus, S127

Salicylic acid

Cucumber mosaic virus 2b RNA silencing suppressor and, S70

Fusarium oxysporum on melon and production of, 682

plant immunity and, S160

and potato purple top (PPT) phytoplasma in tomato, S208

Salih, M. M., S4

Salinas Valley, food safety research in, S155

Saliva, as vector for Xylella fastidiosa inoculation, S9

Salmonella enterica

outbreaks of, vegetables and, S177

STM0978 and STM0693 genes of, S47

Salsola tragus (tumbleweed)

Colletotrichum gloeosporioides f. sp. salsolae for, $\mathrm{S} 205$

searching for fungi as possible biological control agents of, S64

Salt stress, and Phytophthora spp. on tomato and chrysanthemum, 871

Sampangi, R., S113

Sanchez, K., S113

Sanchez, K. R., S27

Sanders, Jr., F., S113

Sanderson, J. P., 1307

Sanderson, K. R., S100

Sanderson, P. G., S163

Sanderson, R., 21

Sandoval, C., S110

Sang, M. K., 774

Sangchote, S., S121

SanMiguel, P. J., S17

Sano, T., S95

Sanogo, S., S114

Sanssené, J., 1352

Santa-Cruz, J., S114

Santhanam, P., S64

Santos, M., S39, S95

Santos, V. C., S77

Saponari, M., 319

SARRITOR, commercialization of, S162

Sarver, B. A. J., 58

Sasaki, A., 922

Sastoque, L., S42

Satoh, M., 85

Sattler, S. E., S37, S185

Saurat, C., 105

Savary, S., S136, S156

Saville, B. J., S87

Sayler, R. J., S114

SBFS. See Sooty blotch and flyspeck; Sooty blotch and flyspeck (SBFS) complex

$\mathrm{Scab}$, on potato, fish emulsion for suppression of, S1 
Scandiani, M. M., 58

Schaad, N., S114, S116, S207

Schaad, N. W., 208

Schaafsma, A. W., S180

Schell, M. A., S45, S66

Schena, L., S76

Scherf, J. M., S115

Scherm, H., S55, S81

Schilder, A. M. C., S9, S83

Schlehuber, S., S37

Schlub, K. A., S115

Schlub, R. L., S82, S115

Schmale, D. G., S208

Schmidt, D., S115

Schmidt, F. J., 1111, S43

Schmidt, L. S., S115

Schneider, B., 863

Schneider, K. L., S78

Schneider, R. W., S22, S115, S134, S203

Schneider, W., S117

Schneider, W. L., S126, S149, S209

Schoelz, J. E., 1111

Scholar, for Penicillium expansum on pome fruit, S163

Scholez, J. E., S43

Scholthof, H. B., S76

Scholthof, K.-B. G., 14

Schreiber, H. L., S115, S116

Schroeder, B. K., S31, S53

Schroeder, K. L., S142

Schubert, T., S116, S172

Schuenzel, E., S116

Schuenzel, E. L., 208

Schultheiss, H., S54, S129

Schultz, P. B., S205

Schumacher, R., S114

Schwab, E. B., S16

Schwandt, J., S166

Schwartz, D., S75

Schwarz, P. B., 290

Schweri, K. K., S116

Sciumbato, G. L., S153

Sclerotinia spp.

S. homoeocarpa (dollar spot) demethylation inhibitor fungicides for S75, S197

early-season fungicide programs for control of, S137

effect of temperature on growth of, S137

genetic diversity of, in Florida, S201

propiconazole for control of, $\mathrm{S} 102$

resistant to fungicides and plant growth regulators, $\mathrm{S} 92$

weather variables for prediction of, S120

S. minor

on lettuce, S91

on peanut, S204

S. sclerotiorum

on bean, $\mathrm{S} 122$

on canola, $\mathrm{S} 184$

on carrots, S65, S100

Coniothyrium minitans for control of, S5

on Dahlia, S5

effect of sclerotial moisture content on

carpogenic germination of, S189

from four crops, genetic variation of, $\mathrm{S} 4$

on lettuce, S24, S91

oxalic acid and redox changes in host cellular environment, S58, S151, S160

population study on Western Australian strains of, S39

predictive model for carpogenic germination of, $\mathrm{S} 89$

on rape, $\mathrm{S} 18, \mathrm{~S} 23$

Sclerotium cepivorum, on garlic, in Maine, S194

Sclerotium rolfsii

characterization of isolates affecting vegetable and row crops in southern U.S., S140

on peanut, S40, S199 on Phalaenopsis orchids, S22

poultry litter for control of, $\mathrm{S} 103$

Scocco, E. A., S116

Scorza, R., S209

Scott, R., S136

Scully, B., S37, S57

Sechler, A., S114, S116, S207

Secor, G. A., 290

Security. See Food security

SecY gene, differentiation of phytoplasma genes

based on phylogenetic analysis of, S69

Seebold, K. W., S153

Seed industry, crop biosecurity and, S155, S181

Seeland, T. M., 33

Seem, R. C., 246, 1240, S8, S38, S88

Seemüller, E., 863

Sekar, J., S116

Selote, D., S117

Semenov, A. M., 593

Semer, C. R., S40

Sengodagounder, V., S88

Seo, Y.-S., 1089

Sep-lveda, P., S99, S110

Septoria spp.

S. musiva, on Populus spp., breeding for resistance, $\mathrm{S} 196$

S. passerinii, on barley, resistance loci for, 80

predicting activity of experimental fungicides for using multiple regression modeling, on wheat, S63

S. tritici, on wheat, S36, S51

Sequence-based identification

of fungi and oomycetes, promise and pitfalls of, 732

viruses and, S154

Serdani, M., S104

Serine proteases, Clavibacter michiganensis on tomato and, 252

Serratia marcescens, for control of root-knot nematode on tomato in Egypt, S1

Serrato, L. M., S176

Sessa, G., 252, S22

Sétamou, M., S66

Sether, D. M., S82

Setubal, J. C., 208

Severinia buxifolia, Candidatus Liberibacter asiaticus on, $\mathrm{S} 107$

Severity of disease. See Disease severity

Sexton, P. J., S194

Shabana, Y., S176

Shah, K. H., S117

Shah, S., S130

Shahbazi, H., 454

Shamsbakhsh, M., S31

Shan, W., S158

Shao, J., S29, S95

Sharma, K., S117

Sharma, S. K., S96

Shatters, R. G., S6

Shaw, B. D., S62, S133

Shaw, J. N., S86

Shaw, M. W., S49

Shennan, C., S19

Sherman, D., S117

Sherman, D. J., S209

Shi, X., 822, S118

Shim, W., S62, S76, S94, S109, S133

Shimabuku, R., S82

Shinogi, T., 840

Shinya, R., 1289

Shirai, M., 436

Shiraishi, A., S118

Shishkoff, N., S136

Shock, C., S113

Shoemaker, R., S189

Shokes, F. M., S153

Shrestha, B., S47

Shtienberg, D., 97

Shu, X., S38
Shuai, B., S118

Shyu, C., S11

Sick Plants and a Hungry World, online course for master gardeners, S33

Sieburth, P. J., 319

Sierotzki, H., S49, S162

Signaling, activation of secondary metabolites with multiple roles in biological control, S159

Sikora, E., S30

Sikora, E. J., S118

Silber, A., 913

Silicon

for Colletotrichum orbiculare on cucumber, S174

for Cylindrocladium spathiphylli and Mycosphaerella fijiensis on banana, S58

for Fusarium oxysporum on tomato, S52

for Fusarium spp. on cucurbits, S18, S205

for powdery mildew on zinnia, S74

for Ralstonia solanacearum on tomato, S88

for Tobacco ringspot virus, S144

transporters of in wheat, S196

for Xanthomonas perforans on tomato, S178

Silva, P., S110, S118

Silva, V., S187

Silva Junior, G. J., S118, S119

Silva-Rojas, H., S6

Silva-Rojas, H. V., S119

Silveira Baggio, J., S119

Silver, oxidized, as safe, effective seed treatment, S48

Simard, M., S197

SIMBLIGHT1 and SIMPHYT1 models, for Phytophthora infestans outbreaks, S92

Simmons, A., S103

Simon, A., S105

Simon, J., S198

Simon, L., S121

Simonson, A., S59

Simplicillium lanosoniveum, for control of Phakopsora pachyrhizi on soybean, S134

Simpson, C. E., S204

Singer, S., S50

Singh, A., S119

Singh, D., S93

Singh, R., S85

Single nucleotide polymorphisms (SNPs)

for genetic diversity of Phytophthora capsici, S47

for relationships among Wheat streak mosaic virus isolates, $\mathrm{S} 110$

in Sirococcus clavigignenti-juglandacearum, S17

in Wheat streak mosaic virus, $\mathrm{S} 18$

Sink, S., 58

Sinn, J. P., 539

Sirococcus clavigignenti-juglandacearum, reclassification of into genus Ophiognomonia, S17

Sistani, K., S30

Sisterson, M., S119

Sivasithamparam, K., 551, S35, S39, S60

Skaltsas, D., S119

Skaria, M., S66

Skatenok, O. O., S64

Skelsey, P., 1146, S120

Skelton, L. L., S155

Skipper, C. E., S115, S116

SkyBit, agreement between apple scab and fire blight forecasts of, S46

SLB. See Southern leaf blight

Sliva, D., S131

SM3, from Trichoderma virens, biological control and, S27

Smart, C. D., S20

Smart phone technology, turfgrass disease identification and management using, S78

Smeda, J., S108

Smiley, R. W., 216

Smith, A. G., S70 
Smith, A. J., S120

Smith, B. J., S83, S134

Smith, C. A., S196

Smith, D., S137

Smith, D. L., S98, S120

Smith, D. S., S69

Smith, J., 848, S16

Smith, J. A., S82, S174, S176, S177

Smith, J. E., S120

Smith, J. T., 127

Smith, K. P., 80

Smith, L., S44

Smith, M. J., S120

Smith, R. J., S3

Smith, T. R., S175

Smither, M. R., S1

Smits, T. H., S54, S59, S120

Smooth cordgrass, S195

Snails. See Helix aspersa (brown garden snail)

Snap bean. See Phaseolus vulgaris

Snelling, J., S157

snf1 gene, of Ustilago maydis, as dual regulator of

cell wall degrading enzymes, 1364

Sniezko, R. A., S120, S167

Snook, M., S10

Socha, C., S19

Soil

anaerobic soil disinfestation, $\mathrm{S} 19$

Aspergillus flavus in, $\mathrm{S} 124$

biodisinfection of, S39

electrical conductivity for management of

Rotylenchulus reniformis in, S86

Fusarium spp. in, S73, S80

microbial aspects of accelerated degradation

of metam sodium in, 367

microbial communities of, $\mathrm{S} 41$

Pythium spp. in, 593, S73

Rhizoctonia spp. from, $\mathrm{S} 121$

steaming of, S18

and Verticillium dahliae on strawberry, S193

Xanthomonas citri subsp. citri in, S42

Yigo Experiment Station, S82

Soil phytophathometry, for detection of Fusarium oxysporum on tomato, S29

SoilGard 12G, for nematodes and soil borne

diseases in fruiting vegetables, S50, S200

Sokhandan, N., S87

Sokhandan Bashir, N., S121

Solano, F., S62

Solanum spp.

S. lycopersicum (tomato)

14-3-3 protein of, $\mathrm{S} 92$

Alternaria solani on, in North Carolina, S55

arbuscular mycorrhizal fungi on, S173

biofungicides for disease control on, S196

Botrytis cinerea on, 225, 400

Candidatus Liberibacter solanacearum on, S50, S173

chilling injury in, S12

Clavibacter michiganensis on, 252, S13, S22, S140

effects of grafting on, S20

Fusarium spp. on, S29, S52, S73, S101, S135

grafting for management of Ralstonia solanacearum, $\mathrm{S} 109$

Groundnut ringspot virus on, S134

late blight crisis of, S161

mulches with biofungicides for managing diseases in, S91

new topsovirus of to North America, S100 nutsedges in, S176

pathogens, biological control agents, climate change and, S33

Pelargonium zonate spot virus in, 798

Pepper golden mosaic virus in, S50

Phytophthora spp. on, 97, 619, 871, Cover photo June, S29, S147 postharvest decays of, S33

potato purple top (PPT) phytoplasma in,

S135, S207, S208

Potato spindle tuber viroid in, S95

Pseudomonas solanacearum on, S34

Psudocercospora fuligena on, S82

Pythium spp. on, S73

Ralstonia solanacearum on, S15, S55, S88

Rhizoctonia solani on, 493

Tobacco mosaic virus in, in Tehran, S4

Tomato chlorosis virus in, 582

Tomato yellow leaf curl virus in, $\mathrm{S} 82$

Trichoderma hamatum 382 for control of

Xanthomonas euvesicatoria on, $\mathrm{S} 124$

viral diseases of in Chile, S110

Xanthomonas spp. on, S34, S145, S178

S. phureja (diploid potato)

Phytophthora infestans on, S87

Potato yellow vein virus in, S176

Spongospora subterranea f. sp. sub-

terranea on, S40

Phytophthora infestans in, genetic structure of populations in eastern North America 20022009, S52

resistance to potato virus $Y$ in, $\mathrm{S} 19$

S. tuberosum (potato)

Alternaria solani on, 454, S14

and Bacillus spp. in potato rhizosphere as PGPR inoculant, S20

Candidatus Liberbacter solanacearum on, S138

Clavibacter michiganensis subsp. sepedonicus on, $\mathrm{S} 124$

Colletotrichum coccodes on, $\mathrm{S} 93$

Dickeya sp. in, 134, 1128

Fusarium graminearum on, 290

late blight of, S26, S161

modeling climate change and late blight risk, S121

Pectobacterium spp. on, S31, S70

Phytophthora erythroseptica on, S183

Phytophthora infestans on: in Colombia, S21, S22; dihydroorotase dehydrogenase from, S39; intragenic technology for disease resistance, $\mathrm{S} 101 ;$ MES1 gene and systemic acquired resistance, S77; molecular interactions determining broadspectrum partial resistance, S46

Potato virus $S$ in, $\mathrm{S} 1$

Potato yellow vein virus in, S176

Pratylenchus penetrans on, S180

Pseudomonas syringae pv. tomato on, S23

Ralstonia solanacearum on, 1250

Rhizoctonia solani on, S32

Spongospora subterranea f. sp. subterranea on, $\mathrm{S} 40$

Streptomyces spp. on, 460, S82

Trichoderma asperellum and Spongospora subterranea on, $\mathrm{S} 40$

Verticillium spp. on, S67

zebra chip disease of, $\mathrm{S} 203$

Soler, J., S40

Soltani Nejad, S., S113

Somatic cell selection, using thaxtomin A, potato resistance to common scab, 460

Somatic cybridization, in citrus, Xanthomonas citri subsp. citri resistance and, S37

Sommerhalder, R. J., 855

Sone, T., 612

Song, B., 183

Song, W., S97

Sonoda, R., 612

Sooty blotch and flyspeck (SBFS) complex of apple

diversity and biogeography in eastern and midwestern U.S., 345

in Iowa, phenology of natural inoculation, S54

lime-sulfur for, S197

in Turkey, S15
Sopee, J., S121

Sorghum

allelopathy against wheat, S2

as bioenergy crop in Alabama, S16

Fusarium thapsinum and Curvularia lunata on, S90

Peronosclerospora sorghi on, S106 plant diseases in, S180

Pseudomonas spp. on, S37, S106

Sorgoleone, and sorghum allelopathy against wheat, S2

Soto-Arias, J., S148

Sour cherry, Aureobasidium pullulans for controlling brown rot blossom blight of, S51

Southern leaf blight (SLB), in maize, mapping quantitative trait loci for, multiple disease resistance and, 72

Southern rice black-streaked dwarf virus

(SRBSDV), in rice, in China, S146

Souza, A. G., S121

Sowa, D. A., S48

Soybean. See Glycine max

Soybean cyst nematode. See Heterodera glycines

Soybean dwarf virus (SbDV), effect of new aphid vectors on evolution of, S126

Soybean mosaic virus (SMV)

pipo gene of, $\mathrm{S} 135$

prevalence, incidence, and spatial dependence in Iowa, 931

seed transmission of, genes involved in, S57

vector systems from for exploration of soybean cyst nematode-plant interactions, S187

Soybean rust. See Phakopsora pachyrhizi

SPACES site, update on, S94

Spadafora, V. J., S166

Spaine, P. C., S94

Spaine, P. O., S82

Spanu, P., S56

Sparks, A., S121

Spartina alterniflora (smooth cordgrass),

Fusarium aestuarinus on, S195

Spathiphyllum, Phytophthora nicotianae on, S125

Specialization, lack of in Fusarium graminearum

and $F$. pseudograminearum, 1057

Speers, C., S69

Sphaerotheca spp.

Regalia for control of, synergistic effect with other fungicides, S123

on squash, evaluation of biological control agents for, $\mathrm{S} 145$

Spiers, J., S71

Spinach

BAC library from, S35

Verticillium dahliae on

effect of limestone on, S142

qPCR assay for detection and quanti-

fication of in seed, $\mathrm{S} 107$

seed as source of on lettuce, S8

virulence and molecular characterization of, $\mathrm{S} 53$

Spolti, P., S121

Spongospora subterranea, on potato, S40

Spooner, D., S19

Sporisorium holci-sorghi, on corn, S36

Spósito, M. B., S118, S119

Spring dead spot (SDS), Ophiosphaerella

herpotricha on bermudagrass, 415

Springfield, T. N., 493

Spring-Pearson, S., 601

Spurlock, T. N., S121, S203

Squash. See Cucurbita pepo

Squash vein yellowing virus (SqVYV) in watermelon

ELISA and qPCR for detection of, S134

viruses in single and mixed infections, 1194

Sr9e and Sr13, and virulence of Puccinia graminis f. sp. tritici on wheat, S93

Sreedharan, A., S122 
Srinivasachary, A, S136

Srinivasan, R., S122

Srivastava, P., S122

St. John, R., S91

St. Martin, S., S189

St. Martin, S. K., S190, S192

Stacey, G., 1111, S68

Stack, J., S181

Stadnik, M. J., S122

Stafford, C. A., S122

Stagonospora nodorum on wheat

effect of temperature on latent period, S144, S204

effector-induced host susceptibility pathways, $\mathrm{S} 151$

in Norway, S36

survey of toxins and sensitivity genes in southeastern U.S., S144

Stammler, G., 522, S37

Stanghellini, M., S122

Stansly, P. A., S77

Starch granules, and remnants of host-pathogen molecular interactions, 848

STAR-D (System for True, Accurate, and

Reliable Diagnostics), overview of, S177

Starr, J., S123

Starr, J. L., S199

State regulatory inspection service, potato and tomato late blight crisis and, S161

Steadman, J., S122

Stebbins, T. C., S169

Steddom, K., S123

Steffenson, B., 80, S157

Steger, A., S26, S31

Stein, J. M., S15

Steiner, B., 367

Stenger, D. C., S68

Stenocarpella macrospora, on corn in Brazil, ITS sequence analysis of, S36

Stenocarpella maydis chiA as a potential genetic marker for resistance against, $\mathrm{S} 88$ on corn in Brazil, S36 modification of maize protein by, 645

Stenotaphrum secundatum (St. Augustine grass),

Rhizoctonia solani on, S36

Stensvand, A., 246, S8

Stephenson, R. C., S112, S123

Stevens, M., S147

Stevenson, K. L., S9, S105, S126

Stewart, P., S60

Stewart, S. M., S123, S190

STM0978 and STM0693 genes, of Salmonella

enterica, and plant colonization, S47

Stockwell, V. O., 1330, S59, S120

Stolz, M., S23

Stomata, of Arabidopsis, and defense against

bacterial infection, $\mathrm{S} 24$

Stone, A. L., S42, S209

Stone, C. L., S37

Stone, E. A., S85, S92, S157

Stouthamer, R., 601

Stover, E., 239

Stowell, L., S152

Stoxen, S., S156

Strausbaugh, C. A., S123

Strawberry. See Fragaria spp.

Strawberry latent ringspot virus, in mint, S109

Strawberry mild yellow edge virus, in ecotypes of

Chilean native strawberry, S110

Streptomyces spp.

and bacteriophage, for biological control of Pseudomonas solanacearum and Xanthomonas campestris on tomato, S34

S. lydicus, for management of Fusarium oxysporum f. sp. niveum on watermelon, S51

S. scabiei

on potato, 460

thaxtomin A production by, 91
S. stelliscabiei, on potato, $\mathrm{S} 82$

Striatin, of Colletotrichum graminicola, and mycelial growth, conidiation, and virulence to maize, $\mathrm{S} 133$

Strobilurin fungicides, for Cercospora zeaemaydis on corn, S202

Stubbs, G., S60

Stuchi, E. S., S41

Sturrock, R. N., 356

$\mathrm{Su}, \mathrm{H} ., \mathrm{S} 123$

Suárez, A., S171

Subbarao, K., S53

Subbarao, K. V., 1222, S8, S24, S53, S64, S79, S107

Subedi, N., S124

Suberin, and thaxtomin A production, by Streptomyces scabies, 91

Succinate-dehydrogenase inhibitors mutations in target protein of, fungicide sensitivity and, S37

for Mycosphaerella graminicola, resistance against, $\mathrm{S} 12$

Suciu, D., S117

Sucrose metabolism, and Ralstonia solanacearum on tomato, S55

Sudarshana, M. R., S3

Sudden vegetation dieback, on smooth cordgrass,

Fusarium aestuarinus and, S195

Sugar, D., 1330

Sugar beet. See Beta vulgaris

Sugar beet cyst nematode, resistant catch crops and decline of, S84

Sugarcane. See Saccharum spp.

Sugarcane streak mosaic virus (SCSMV), in sugarcane, multiple infection in single plant, S140

Sugarcane yellow leaf virus (SCYLV) molecular diversity of, S132 on sugarcane, $\mathrm{S} 43$

Sugawara, K., S52

Sugiyama, M., 560

Suh, S., S130

Sui, D. D., S107

Suizu, Y., S90

Sule, S., 863

Sullenger, A. R., S9

Summers, C., S129

Sumner, D. R., S153

Sun, H. Y., 522

Sun, J., S73

Sun, X., 208, 567, S24

Sun, X.-C., 468

Sundaram, S., S104

Sundin, G., S23

Sundin, G. W., 345, S69, S80, S166

Sung, S. S., S94

Sunkar, R., S3

Sunn hemp. See Crotalaria juncea

Surface coat proteins, of pine wood nematode, during host pine infection and in vitro culture, 1289

Surfactant

from Bacillus mojavensis, S10

and germination of Myrothecium verrucaria conidia, S57

Sutherland, A. M., S124

Sutton, T. B., 345

Sweany, R., S28

Sweany, R. R., S124

Sweet cherry. See Prunus avium

Sweet orange. See Citrus sinensis

Sweet potato. See Ipomoea batatas

Sweet potato leaf curl virus (SPLCV), for agroinfection, $\mathrm{S} 95$

Sweets, L., S137, S185

Switchgrass. See Panicum virgatum

Sykes, V. R., S80, S152

Synchytrium solstitiale, for biological control of yellow starthistle, S34, S206
System for True, Accurate, and Reliable

Diagnostics (STAR-D), overview of, S177

Systemic acquired resistance

against Xanthomonas citri subsp. citri, soil application of neo-nicotinoid insecticides and acibenzolar-S-methyl for, S42

against Xanthomonas translucens pv. poae, of annual bluegrass, S23

Syverson, R. L., S124

Szabo, L. J., 432, S27, S156

Taber, S., S174

Taberner, V., S86

Tabor, G., S164

Tada, Y., 85, 120

Tagetes spp. (marigold), Alternaria tagetica on, Heritage 50 WDG fungicide for control of, S46

Tailocin, from Burkholderia cepacia complex, S31

Tajima, S., 85

Takahashi, M., 612

Takahashi, Y., 747

Take-all disease, and Gaeumannomyces graminis var. tritici, 404

Takeuchi, Y., 1289

TAL effectors, Xanthomonas oryzae pv. oryzae and, S159

Talezari, A., S124

Tall fescue. See Festuca arundinacea

Tallapragada, P., S208

Talledo Albujar, M. J., S125

Tally, A. H., S165

TAM O-201 locus, and resistance of wheat against Puccinia coronata, 484

Tan spot, Pyrenophora tritici-repentis on wheat genetic diversity of mating type and toxin production genes, 474 QTL for resistance against, 460

Tanaka, K., 85

Tande, C., S59

Tangerine. See Citrus reticulata

Tanoak. See Lithocarpus densiflorus

Tanzarella, O. A., 390

Tarnowski, T. L., S125

Tatineni, S., 230, S125

Taylor, C. L., 493

Taylor, E., S172

Taylor, R. J., S183

TctE/tctD, and Xanthomonas oryzae pv. oryzae virulence, $\mathrm{S} 25$

Te Beest, D., S125

Tebuconazole adaptation of Fusarium graminearum to, 436 for Cercospora arachidicola on peanut, S105 for Puccinia graminis f. sp. tritici on wheat, S44

Tech, K., S95

Tedford, E., S163

Tegg, R. S., 460

Teichmann, B., S198

Teixeira, D. C., S74

Teliz, D., S89

Tello, J., S95

Tello Marquina, J., S29, S39

Temsah, M., S111

TENGU phytoplasma, and witches' broom and dwarfism, S52

Tenuta, A., S185

Tertuliano, M., S199

Tetrazolium violet, for staining sorghum caryopses, S90

Tewolde, H., S30

Texas Phoenix palm decline (TPPD), of palm, Candidatus Phytoplasma palmae-related strain and, $\mathrm{S} 175$

TFT7, of tomato, and immunity-associated programmed cell death, S92

Thaher, N. H., S125

Thannhauser, T., S100 
Thaxtomin A

somatic cell selection using, 460

Streptomyces scabies production of, 91

Thaxton, P. M., S153

Thermotherapy, for elimination of Black rasp-

berry necrosis virus in, S56

Thielaviopsis basicola, on cotton, quantifying changes in root architecture caused by, S75

Thies, J. A., S65

Thiophanate-methyl, for Botrytis cinerea on strawberry, S6

Thomas, A., S9, S126

Thomas, B. J., 21

Thomashow, L. S., S85, S141

Thomma, B. P., S64

Thompson, D. C., S126

Thonart, P., S158

Thorne, J., S68

Thousand cankers disease, Geosmithia morbida on walnut, status in California, S48

Thowthampitak, J., S103

Thrips tabaci, as vector for Iris yellow spot virus, S122

Thru Ppoyil, S., S190

Thru Ppoyil, S. B., S126

Tian, B., S126

Tian, G., 593

Tilletia spp.

survival of secondary sporidia of, 645 on wheat, S41, S104

Time, I., S126

Timmer, L., S174

Timmer, L. P., S85

Tisserat, N., S153

Tisserat, N. A., S127

TMV inclusion bodies, virus accumulation and S142

Tobacco. See Nicotiana spp.

Tobacco mosaic virus (TMV), in tomato in

Tehran, incidence and variation of, $\mathrm{S} 4$

Tobacco ringspot virus (TRSV)

effects of and accumulation of silicon on, $\mathrm{S} 144$

in mint, detection and analysis of, S109

Todd, J. C., 1138

Tolin, S. A., S173, S205

Tomaso-Peterson, M., S126

Tomato. See Solanum lycopersicum

Tomato bushy stunt virus, expression vectors based on, S76

Tomato chlorosis virus (ToCV), in wild tomato, resistance against, 582

Tomato ringspot virus (ToRSV), in grape in Maryland, S88

Tomato spotted wilt virus (TSWV) complementation between viruses in datura, S10

and feeding behavior of Frankliniella occidentalis, $\mathrm{S} 122$

NSm proteins of, S70

in peanut, $\mathrm{S} 105$

in pepper in Taiwan, S53

Tomato yellow leaf curl China virus (TYLCCNV), AV2 protein of as silencing suppressor, S139

Tomato yellow leaf curl virus (TYLCV)

and helper viruses, betasatellite, and DNA-2 satellite, S53

in tomato in Hawaii, S82

Tom-Cast, for control of tomato disease, S147

Tomlinson, J. A., 143

Tong, L., S77

Tooley, P. W., S208

Torres Puyo, C., S110, S118

Torreya taxifolia (Florida torreya), Fusarium

lateritium on, $\mathrm{S} 174$

Tosa, Y., 436

Toth, I. K., S80

Townley, M. A., S77
Toxoflavin, and Burkholderia glumae on rice, S96

Transposon mutagenesis, of Pantoea ananatis, for mutant with reduced virulence, $\mathrm{S} 144$

Trapero, A., 1340

Trapero-Casas, A., S86

Travadon, R., 708

Travers, S. E., S4

Travis, J. W., 345, 539, S46, S49, S100

Tredway, L. P., S75

Trees. See also Specific trees

eastern Canadian, Phytophthora ramorum on S197

Phytophthora ramorum on, screening Gulf

Coast forest species for susceptibility, S202

structural defense mechanisms in, S197

wetwood/water pocket and, S198

Trelles Di Lucca, A., S125

Tremblay, A., S127

Tremblay, G., S193

Trently, D. J., 493

Triazole, for Rhynchosporium secalis on barley, S49

Tribolium castaneum (red flour beetles),

Aspergillus spp. in, S29

Trichoderma spp.

T. asperellum, Spongospora subterranea and, on potato, $\mathrm{S} 40$

in crop management systems, S165

T. hamatum 382, for Xanthomonas euvesicatoria on tomato, $\mathrm{S} 124$

T. harzianum

for alleviation of biotic, abiotic, and physiological stresses in germinating seeds and seedlings, 1213

for control of root-knot nematode on tomato in Egypt, $\mathrm{S} 1$

and hormone production caused by $F u$ sarium oxysporum on melon plants, 682

for pathogens on French beans in Kenya, S60

T. virens

for control of nematodes and soil-borne disease in vegetable production, $\mathrm{S} 50$

SM3 from, biological control and, S27

in vitro evaluation against fungal trunk disease pathogens in Mexico, S101

Trichodorus primitivus, in Golestan National Park in Iran, $\mathrm{S} 124$

Trichothecene, associated with Fusarium graminearum, 290

Trifloxystrobin

for Cercospora sojina on soybean, S145

for Colletotrichum acutatum on citrus, S118

Trifolium subterraneum (subterranean clover), 551

Trigiano, R., S71

Triky-Dotan, S., 367

Trinidad Chipana, E., S125

Trioza apicalis (carrot psyllid), on carrot, and

Candidatus Liberibacter solanacearum, S88

Tripathy, S., S190

Triplett, L. R., S127

Triticum aestivum (wheat)

Blumeria graminis on, 1352

Cochliobolus sativus on, S45, S76

effect of environment, cultivar, and disease on, in Wisconsin, S67

evaluation of world genetic collections to resistance against harmful pathogens, S65

Fusarium graminearum on aggressiveness of chemotypes with different levels of disease resistance, S189

Bacillus spp. for control of, S87

collection of isolates 40-300 meters above ground, S208

correlation between disease severity and deoxynivalenol, S186

cytochrome p450 gene and resistance, 183 deoxynivalenol and nivalenol accumu- lation in, 763

deoxynivalenol production in North

Dakota, 1007

epidemics in Nebraska, 2007 and 2008,

S191

evaluation of cultivars for resistance, S50, S186

glyphosate effect on DON content and inoculum production, S193

grain yield, cultivar resistance and, S113

monitoring using quantitative real-time

PCR, 49, Cover photo February

in Ohio, El Niño-Southern Oscillation and atmospheric teleconnection patterns, S66

plant height and severity of crown rot, 1276

single-kernel near-infrared technology to sort kernels based on scab and deoxynivalenol levels, S134

spatial heterogeneity in disease incidence, S65

triazole-based fungicides for, 160

validation and haplotyping of resistance genes in diverse germplasm, $\mathrm{S} 104$

Gibberella zeae on

and deoxynivalenol in kernels, 719

influence of mating pheromones and affinity-selected peptides on, S43

leaf blotch disease complex on, in Norway, S36

leaf wetness duration and disease epidemiology, S76

mass spectrophotometric analysis of, 848

Mycosphaerella graminicola on

airborne inoculum of during growing season in Belgium, S26

analysis of populations from multiple states with mating type and SSR markers, S45

pathogen hijacking of disease resistance mechanisms in, S151

Puccinia spp. on

P. graminis f. sp. tritici, $\mathrm{S} 44, \mathrm{~S} 93$

P. striiformis f. sp. tritici, 313, S53, S132

P. triticina, 376

PWT1 avirulence allele of Magnaporthe oryzae, 436

Pyrenophora tritici-repentis on, 460, 474, S45

Rhizoctonia solani on, S142

Septoria tritici on, S51

silicon transporters in, S196

sorghum allelopathy against, S2

Stagonospora nodorum on, S144, S151, S204

Tilletia spp. on, S41, S104

Wheat streak mosaic virus and Triticum mosaic virus coinfection of, 230

Xanthomonas campestris pv. translucens on, S59

Xanthomonas translucens pv. undulosa, S3

Triticum mosaic virus (TriMV), in wheat, and

Wheat streak mosaic virus coinfection, 230

Trititrigia Zhong 4, Puccinia striiformis f. sp.

tritici on, $\mathrm{S} 133$

Trivedi, P., S127

Trogolo, J. A., S61

Tronsmo, A., S8

Tronsmo, A. M., 246

Trouillas, F. P., 1048

Trujillo, C. A., S127

Tsai, C., S184

Tsai, C.-W., 830

Tschaplinski, T., S160

Tsn gene, and pathogen resistance in wheat, $\mathrm{S} 151$

Tsror (Lahkim), L., 271

Tsuge, T., 120

Tubaro, F., 390

Tucker, D., S189

Tucker, D. M., S190

Tudzynski, B., S18 
Tuffen, M. G., S127

Tumbleweed. See Salsola tragus

Turechek, W., S127

Turechek, W. W., 239, 1194

Turfgrass. See also Specific grasses

fifty years of breeding for disease resistance in, S193

isoparaffin-based oil for controlling dollar spot and gray leaf spot in, S208

Labyrinthula terrestris on, S204

macroarray detection of pathogens of, $\mathrm{S} 90$

Rhizoctonia spp. on, S152

Rhizoctonia-like spp. on, S152

Sclerotinia homoeocarpa on, $\mathrm{S} 92$

Waitea circinata on, $\mathrm{S} 152$

Turina, M., 1100

Turner, R. S., S78

Turnip crinkle virus (TCV)

role of capsid protein in viral systemic movement, $\mathrm{S} 105$

R-protein mediated resistance to, S56

Turnip mosaic virus (TuMV), in Arabidopsis,

differential regulation of host mRNA translation initiation, S188

Turoop, L., S128

Tweddell, R., S65

Tweddell, R. J., S193

Twieg, E., S73

Twizeyimana, M., S128, S190

Tychon, B., S32, S76

Tylenko, D. P., S100

Tyler, B., S190

Tyler, B. M., S158

Tyler, D., S30

Tylka, G., S30, S185

Tylka, G. L., S190

Type III secretion systems

of Dickeya dadantii, $\mathrm{S} 144$

of Pantoea stewartii subsp. stewartii, S27, S184

of Ralstonia solanacearum, S55

for screening for effectors of Blumeria graminis f. sp. hordei, S56

small molecule inhibitors of in Gram-negative pathogens, $\mathrm{S} 160$

Xanthomonas oryzae pv. oryzae and, S159

Type VI secretion system, of Xanthomonas axonopodis pv. manihotis, S86

Tzanetakis, I., S67

Tzanetakis, I. E., S103, S112, S128, S201

Tzeng, K., S71

UBL1 gene, and Fusarium verticillioides colonization of corn, S148

Uchida, J., S118, S128

Uddin, W., S106

Udvardi, M., S40

Ueda, M., 1289

Ueng, P., S59

Ullah, H., S128

Ullman, D. E., S122

Ulvan, for Colletotrichum gloeosporioides on apple, S122

Unfolded protein response, Arabidopsis BAG7 gene and, S58

Upe pathogenesis gene, of Ustilago maydis, $\mathrm{S} 24$

Uppala, S., S128

Uppalapati, R., S160

Uppalapati, S., S129

Uppalapati, S. R., S54

Upper, C. D., 986

Ur-3 gene, Uromyces appendiculatus on bean and, $\mathrm{S} 98$

Urashima, A. S., S78

Urbez-Torres, J. R., S129

Urea sprays, for Venturia inaequalis on apple, S196

Uribe, P., S14

Urine, cow, suppression of Rhizoctonia solani on rice by, S56

Uromyces appendiculatus, on bean, Ur-3 gene and, S98

Urrea, K., S129

Urrea, K. E., S203

Urrea, R., S129

USDA-APHIS

diagnosticians and, S168

permitting and regulatory policy changes: impact on stakeholders, S131

plant pest permitting and containment facilities, S61

potato and tomato late blight crisis and, S161

Ustilaginoidea virens, on rice, in Arkansas, S125

Ustilago maydis

on corn, cytokinin biosynthesis and pathogenesis, S87

snfl gene of, as dual regulator of cell wall degrading enzymes, 1364

Upe pathogenesis gene of, $\mathrm{S} 24$

velvetA (veA) homolog in, and hyphal proliferation in maize, S59

Ustilago scitaminea, Herbaspirillumn seropedicae and Azospirillum brasiliense for control of, S111

Uyemoto, J. K., S3

Vaccinium spp. (blueberry, cranberry)

Botryosphaeriaceae on, $\mathrm{S} 138$

Colletotrichum acutatum on, rapid screening for resistant lines, $\mathrm{S} 83$

V. corymbosum (blueberry)

Fusarium sp. on, in Argentina, S21 pathogens of in nursery plants, $\mathrm{S} 99$

$V$. meridionale., Alternaria spp. on, S19

$V$. oxycoccos (cranberry)

Helicobasidium sp. on, $\mathrm{S} 94$

Physalospora (Acanthorhynchus) vaccinii on, S101

phosphoric acid from fungicides and fertilizers, S16

postharvest decays of, $\mathrm{S} 81$

Xylella fastidiosa on, S199

Vadivel, K., S129

Vahling, C., S30

Vaiciunas, J., S94

Vaillant-Gaveau, N., 424

Vaira, A., S71

Valdivia, C., S41

Valenzuela-Solano, C., S87, S101

Vallad, G., S129, S140

Vallad, G. E., 1222, S177

Valverde, R. A., S112, S115

Van Bruggen, A., S177

van Bruggen, A. H. C., 593

van den Berg, F., 1169

van den Bosch, F., 638, 1030, 1169

Van den Bosch, F., S51

Van der Does, D., S160

van der Lee, T., 328

van der Werf, W., 1146

van der Wolf, J. M., 134, 1128

van Kan, J. A., S151

Van Rij, N., S181

van Santen, E., S18

van Schadewijk, T., S81

van Veen, J. A., 1128

Van Wees, S. C., S160

Vanasse, A., S193

Van-Ghelder, C., 384

Vargas, A. M., S7, S22, S29

Vargas, H. A., S40

Vasquez, S., S95

Vaughn, V. L., S76

Vazquez-Mundo, M., S29

$V e A$ homolog, in Ustilago maydis, S59

Vectors, for transient expression of recombinant protein in plants, S117

Vega, B., S130
Vegetative compatibility groups of Aspergillus flavus, S43, S85 of Aspergillus parasiticus, S85 of Colletotrichum coccodes, $\mathrm{S} 182$

Velasquez, N. Y., S130

Velvis, H., 134

Vemulapati, B., S130

Venkata, B., S11

Venturi, V., 262

Venturia inaequalis

on apple

benzimidazole resistance, $\mathrm{S} 189$

dodine resistance and, S27

fungicide resistance in, $\mathrm{S} 183$

post-harvest foliar urea sprays to reduce ascospore production, S196

and resistance to DMI fungicides, $\mathrm{S} 100$

fungicide resistance in, in Indiana and Michigan, S23

QoI inhibitors for, and resistance in Michigan, S69

Vera Cruz, C. M., S11, S157

Vercauteren, A., S42

Verhalen, L. L., S153

Verma, S. S., S130

Vermeire, M., S58

Veronese, P., S64

Verticillium spp.

V. albo-atrum and Verticillium dahliae, S64

V. dahliae

Agrobacterium tumefaciens-mediated transformation of, S79

on cotton, S75, S140

intergenic spacer region of, $\mathrm{S} 79$

on mint, S77

mitochondrial haplotype analysis for differentiation of races, $\mathrm{S} 78$

molecular variation among, mitochondrial haplotype analysis for differentiation of races, 1231

molecular variation among, PCR-based differentiation of races and, 1222

on peanut, pod yield and, S204

quantification and rapid detection of in soil, S14

on spinach: effect of limestone on, S142; in seed, qPCR assay for detection and quantification, S107; seed as source of in lettuce in California, S8; virulence and molecular characterization of, S53 on strawberry, $\mathrm{S} 193$

and Verticillium albo-atrum, S64

on potato, management with crop rotations, S67

species limits and evolution of, S53

Vesicle-associated penetration resistance, $H$ gene and resistance to Hessian fly and, 279

Vicente, M., S86

Vico, I., 42, S56, S58

Victoriocin

characterization of as novel broad-spectrum antifungal protein from Helminthosporium victoriae, 880

overexpression of gene for enhanced antifungal properties, 890

Vidaver, A. K., S38, S187

Vidic, U., S81

Vigaya Satya, R., S117

Vigna radiata (mung bean), Annamalai mixture for control of pathogens in, S129

Vijay Krishna Kumar, K., S170

Villamor, D. V., S130

Villani, S., S27

Villanueva, L. M., S130

Vinatzer, B. A., 208

Vincelli, P., S6

Vincent, M., S80

Vining, K. J., S77

Viroids 
evolution of, S149

multiplex real-time RT-PCR assay for simultaneous detection of, S72

Virulence factors, of Xylella fastidosa, role of cdi-GMP biosynthesis genes, S7

Viruses

bioinformatic analysis of microarray and next generation sequencing data, S154

broad-spectrum resistance against, oligoadenylate system and, S38

in cowpea, effect of multiple infections on seed transmission in, $\mathrm{S} 92$

evolution of geminiviruses vs. RNA viruses, S149

evolutionary and systems biology of emerging, S149

filamentous, structural studies of by X-ray fiber diffraction and cryo-electron microscopy, S60

genomic sequencing for population analysis, S154

and high-throughput sequencing, S154

immunocapture RT-PCR for detection of, S139

microarray-based detection and identification, S10

national standard for certification of ornamental and fruit tree nursery stock and, S135

Nepoviruses, characterization of by integrated approach, S81

next-generation sequencing and virus ecology, S154

overview of evolution of, S149

and Phomopsis longicolla on soybean, interactions between, S148

of plants in Great Smoky Mountains National Park, S112

population processes and evolution of, S149

real-time PCR for sensitive detection of panel of, S72

simple extraction method for detection of, S101

in soybean, in Nigeria, S126

TMV inclusion bodies and, S142

universal plant virus microarray development and validation, S154

Virus-induced gene silencing (VIGS)

Fusarium virguliforme inoculation methods for VIGS study of soybean sudden death syndrome, S187

in Nicotiana tabacum with Tobacco curly shoot virus, S52

novel bipartite launch system for a potexviral vector for, S71

and soybean resistance against Phakopsora pachyrhizi, S96

Vitis spp. (grape)

Aspergillus spp. on, S95

Erysiphe necator on, S38

Grapevine virus A on, in Washington, S81

Phaeomoniella chlamydospora on, in Mexico, S87

Phomopsis viticola on, S6

Plasmopara viticola on, S194

Tomato ringspot virus in, $\mathrm{S} 88$

$V$. vinifera

Arabis mosaic virus on in Iran, S31

Botrytis cinerea on, $\mathrm{S} 49$

co-occurrence of viruses, S90

Erysiphe necator on: density-dependent latency of, S38; from different species and geographic origins, 1185; dynamics of ascospore maturation and discharge 1321; effect of acute low-temperature events on, 1240; environmental conditions and primary infection in Michigan, S9; new biocontrol strategy for, S19 esca disease of, early events prior to visual symptoms, 424
Grapevine leafroll viruses in, S45, S90 grapevine necrotic union on, $\mathrm{S} 3$ mycoviruses in, S5

phosphoric acid from fungicides and fertilizers, S16

Xylella fastidiosa on: biological control of, S52; management strategies for, S201; nutritional treatments and, S16; Pierce's disease and, 1089, Cover photo October

Vitoreli, A., S34

Vitoreli, A. B., S177

Vitoreli, A. M., S110

Vittal, R., S131

Vivancos, J., S196

Vodkin, L., S106

Voisin, R., 384

Voss, H.-H., 904

Vowell, T., S96

Vu, A. L., S131

Vunsh, R., 225

Vy, T. T. P., 436

Waalwijk, C., 328

Wach, M., S163

Wade, L., S166

Wadl, P. A., S45

Wager-Page,' S. A., S131

Waitea circinata, on turfgrass, S152

Wakefield, L. M., S38

Walcott, R., S200

Walgenbach, P. J., S131

Walker, D. R., S122

Walker, G. P., S122

Walker, K., S63

Walker, K. A., S131

Walker, N., S131

Walker, N. R., 415

Walkinshaw, C., S203

Walkinshaw, C. H., S131

Wall, G. C., S178

Wall, M. L., 848

Wallace, R. W., S173

Waller, L., S190

Wallhead, M. W., S113, S132

Wallis, C., S132

Walnut. See Juglans spp.

Walnut twig beetle. See Pityophthorus juglandis

Waltz, C. F., S78

Wan, A., S132

Wang, B., S133

Wang, C., S62, S133

Wang, D., 192, S10, S104, S133, S154

Wang, G., S31

Wang, H., S132, S190

Wang, H. C., 522

Wang, J., 822, S23, S71, S108, S132

Wang, K., S133

Wang, L., S24

Wang, M., S53, S105, S132

Wang, N., S7, S44, S55, S122, S127, S141

Wang, Q., S49, S73, S74, S146

Wang, S., S133

Wang, X., 573, S45, S132, S133, S135

Wang, Y., 573

Wang, Y. G., 1276

Wangdi, T., S54, S160

Ward, L., S70

Ward, L. I., 1282

Ward, N. A., S134, S203

Ward, T., S157

Water extracts of compost. See Compost water extracts

Water pocket, overview of, S198

Watermelon. See Citrullus lanatus

Watermelon mosaic virus (WMV), emerging populations of in southeastern France, 1373

Watson, A., S162

Watson, A. K., S197

Watt, B., S194
Weather balloons, for remote sensing applications for plant pathology, S188

Webster, C., S134

Webster, R. K., 502

Wedge, D. E., S134

Weems, J. D., S191

Weerakoon, M., S134

Wegulo, S., S134, S147, S186, S191

Wegulo, S. N., 230, S50

Wei, W., S135, S206, S207, S208

Wei, Y. M., 1276

Weil, C., S11

Weiland, J., S153

Welch, K. D., S135

Welham, S., 1030

Welker, R., S73

Welker, R. M., S109

Weller, D. M., 404, S85, S141

Welliver, R., S42, S135

Welser, M. J., 246

Wen, A., S135

Wen, J., S146

Wen, R., S135

Weng, Z., S154

Werres, S., S42

Westecott, R., 1057

Westerdahl, B. B., S135

Westerman, R. P., S17

Western Weather Workgroup, forecasting weather and climate for plant disease models, S179

Westphal, A., S136

Westwood, J., S70

Westwood, J. H., S147

Wetwood, overview of, S198

Whalen, M. C., S101

Wharton, P. S., S14

Wheat. See Triticum aestivum

Wheat streak mosaic virus (WSMV) new method for collection and detection of within host, S103 relationships among isolates, $\mathrm{S} 110$ tag-array minisequencing-based system for detecting and genetic fingerprinting, S18 transient expression vector based on, S125 in wheat, and Triticum mosaic virus coinfection, 230

Wheeler, G., S108

Wheeler, H. L., 848

Wheeler, M. J., 345

Wheeler, T., S200

Wheeler, T. A., S136, S138, S153, S173

Whitaker, B., S58

Whitaker, B. D., 42

White, F., S159

White, J., S75

White, T. L., S145, S178

Whitebark pine. See Pinus albicaulis

Whiteflies. See Bemisia tabaci

Whitehead, J., S28

Whitfield, A. E., S184

Whitham, S., S187

Whitham, S. A., S96

Wick, R., S32

Wick, R. L., S195, S196

Wicklow, D. T., 645

Widholm, J. M., 897

Widmer, T. L., S34, S136, S202, S206

Wiemann, P., S18

Wiest, A., S80

Wiglesworth, M., S166

Wilcox, W. F., 1240, S38, S88, S136

Williams, B., S58, S160

Williams, D., S60

Williams, H. L., 356

Williams, J., S38

Williams, J. L., S136

Williams, W. P., S137

Willie, K, S105

Willocquet, L., S136, S156 
Willyerd, K. T., S137

Wilson, A. J., 460

Wilson, C., S137

Wilson, C. R., 460

Wilson, R., S137

Windels, C. E., S16

Windham, A., S71

Windham, G. L., S137

Windham, M., S71

Window-pane methodology, for relationship between yearly fluctuations in Fusarium head blight intensity and environmental variables, 784

Wingo, R. M., S124

Winterhagen, P., S38

Wintermantel, W. M., S103, S128, S138

Winters, S. A., S153

Wirsel, S. G. R., 444

Wise, K., S50

Wise, R., S56, S157

With, K. A., S120

Woeste, K. E., S17

Wolf, J., S208

Wolfe, D. W., S26

Woloshuk, C. P., S62, S108, S109, S138

Woltjen, C. D., S191

Wong, A. W., 345

Wong, F. P., S152, S168

Wood, A., S182

Wood, E., S14

Woodruff, W., S94

Woods, J. L., S138

Woodward, J. E., S136, S138, S200, S204

Woodward, S., S95

Workneh, F., S50, S138, S203

Worley, E., S40

Worthington, C. J., S157

Wraight, S. P., 1307

Wrather, A., S70

Wright, A. F., S138

Wright, D., S181

Wright, D. L., 941, S122, S143, S178, S186, S204

Wright, E. R., S21, S99

Wright, R., S183

WRKY proteins

in low 18:1-derived defense signaling pathway, S38

and response of Arabidopsis spp. to stresses, S47

Wu, B., S24

Wu, B. M., S139

Wu, J., S139

$\mathrm{Wu}, \mathrm{R} ., 91$

$\mathrm{Wu}, \mathrm{T}$., $573, \mathrm{~S} 173$

Wu, W., S135, S206, S207, S208

Wulff, N. A., S74

Wyenandt, A., S198

Wyenandt, C. A., S139, S196

Xanthomonas spp.

$X$. albilineans, on sugarcane, S39, S78, S111

$X$. anxonopodis pv. citri, on calamondin and kumquat, S24

$X$. arboricola pv. pruni, on peach and nectarine, $\mathrm{S} 11$

$X$. axonopodis

on bean, $\mathrm{S} 185$

on cassava, S8, S127

ColS/ColR two-component system and virulence of, $\mathrm{S} 141$

comparative genomic analysis of strains $\mathrm{A}^{\mathrm{w}} 12879$ and 5208, S55

on grapefruit, S71

HrpG and HrpX regulons of, S44

lipopolysaccharide biosynthetic genes of, S71

on soybean, S8, S103

type VI secretion system of, S86

$X$. campestris on Brassica spp., S207

on pumpkin, $\mathrm{S} 108$

on tomato, S34

on wheat, S59

X. citri

copper and streptomycin for, S172

copper resistance in, $\mathrm{S} 13$

on cybrid citrus, S37

on grapefruit, S15, S36, S116

$h r p$ system and pthA and pthB from, S108

soil application of neo-nicotinoid insec-

ticides and acibenzolar-S-methyl for, S42

survival on symptomatic fruit in storage, S172

X. euvesicatoria, Trichoderma hamatum 382

for, on tomato, S124

$X$. fragariae, on strawberry, S64, S83, S174

$X$. hortorum pv. carotae, S139

identification of using Raman spectroscopy, S96

$X$. juglandis, kasugamycin and, S166

$X$. oryzae

AroQ $\gamma$ chorismate mutase and rice virulence, 262

and AvrBs3-related family of transcription activation-like (TAL) type III effectors, S159

genotypic and pathotypic diversity in China, S96

resistance to rice bacterial blight, D-allose and, 85

rpfC control tctE/tctD expression and mutations, reduced virulence and, S25

sequence divergence from oryzicola pathovar, S127

PAMDB and, 208

$X$. perforans

on pepper, $\mathrm{S} 103$

on tomato, S178

on shrub rose, S129, S177

on tomato, evaluation of biological control agents for, S145

$X$. translucens

on annual bluegrass, S23

on wheat, $\mathrm{S} 3$

type III secretion system of for screening for effectors, S56

Xia, J., S139

Xia, J. Q., S72, S139

Xia, X. C., 313

Xia, Y., S139

Xiang, Q., S140

Xiao, C., S63, S143, S163

Xie, C., S140

Xie, L., 822

Xie, Y., S47

Xing, J., S204

Xiong, Z., S154

Xiphinema index and Grapevine fanleaf virus, 384, S93

Xiphinema pachtaicum, in Golestan National Park in Iran, S124

$\mathrm{X}$-ray fiber diffraction, for studies of filamentous plant viruses, $\mathrm{S} 60$

Xu, D., S132, S140, S146

$\mathrm{Xu}$, D.-G., S96

Xu, H. Q., 183

Xu, J., 328, S52, S151

$\mathrm{Xu}$, J. S., 328

$\mathrm{Xu}, \mathrm{L} ., \mathrm{S} 140$

$\mathrm{Xu}, \mathrm{S} ., \mathrm{S} 93, \mathrm{~S} 151$

$\mathrm{Xu}, \mathrm{X} ., \mathrm{S} 13, \mathrm{~S} 140$

$\mathrm{Xu}, \mathrm{X} .-\mathrm{M} ., 814$

Xue, B., S116, S141

Xyleborus glabratus (redbay ambrosia beetle) and

Raffaelea lauricola

on avocado in Florida, S176

on redbay, 1118, S177

Xylella fastidiosa on almond, S119

from almond and grape in California, S24

on Arabidopsis thaliana, S110

biofilm formation and, S28, S72

on blueberry, in southeastern U.S., S199

c-di-GMP biosynthesis genes of, regulatory role, $\mathrm{S} 7$

chitin and virulence and transmission of, S62

differentiation between strains using analysis

of environmentally-mediated genes, S97

disease intensity and yield reduction, in Brazil, S41

expression rate of zot and gyr genes in, S116 genotyping using multiplex PCR, S88

glassy-winged sharpshooter saliva as vector for inoculation, $\mathrm{S} 9$

on grapevine

biological control of, S52

biomarkers for diagnosis of, 1089, Cover photo October

nutritional treatments and, S16

in Washington, management strategies for, S201

LAMP and RT-PCR for rapid detection of, 1282

multilocus sequence typing for, 601

in petioles, detection of, S6

in Pierce's disease, 601, 1089, Cover photo October

plasmid replication and stability factors of, S68

role of c-di-GMP biosynthesis genes in, S7

selection of single chain variable fragments against by phage display, S143

subspecies identification using zot and $g y r$ genes, S115

on tobacco, S29

virulence mechanism in xylem fluid, S118

Yadagiri, K., S204

Yaghmour, M. A., S141

Yajima, W., S130

Yakabe, L. E., S141

Yamamoto, M., 120

Yamaoka, N., S90

Yamasaki, S., 560

Yamasaki-Kokudo, Y., 85

Yan, G. J., 1276

Yan, G. P., 216

Yan, N. F. Almeida, S., 208

Yan, Q., S141

Yang, B., S159

Yang, C., S96, S144

Yang, D., S198

Yang, J., S40, S141

Yang, K., S158

Yang, L., 328

Yang, M., S141

Yang, W., S141, S142

Yang, X., S89, S132, S142, S144

Yang, X. B., 58

Yang, X. M., 1276

Yang, Y., S49, S73, S74, S146

Yao, C., S63, S142

Yao, J. B., 1276

Ye, X., S105

Yellow shoot disease. See Huanglongbing

Yigo Experiment Station, S82

Yin, C., S142

Yin, J., S55, S57, S142

Yin, Y., S63, S143, S163

Yoder, K. S., 345

Yokomi, R. K., 319

Yokota, K., S143

Yoshida, M., 763

Young, C., S7

Young, H., S37

Young, H. M., S143, S178, S204

Young, R. F., S31 
Young, S., S64

Younkins, A., S209

Yu, D., 328

Yu, J., S191

Yu, K., S139

Yu, X., S136

Yuan, L., S204

Yuan, Q., S143

Yuan, X., 601

Yuan, Z. Q., 460

Zablotowicz, R. M., S1

Zacaria, J., 199

Zaccaron, M. L., S144

Zaid, A. M., S144

Zala, M., 172

Zale, J., S131

Zamanizadeh, H., S4, S6, S32, S62, S84, S101, S124

Zampro

for control of oomycete diseases of vine and vegetable crops, S131

for control of Phytophthora capsici on vegetable crops, S57

Zea mays (corn, maize)

aflatoxin in, S1, S8

Aspergillus flavus on

and Acremonium zeae interactions, S137

kernel maturation and transcriptional activity, S108

resistance against, S37

selection indexes to improve resistance to,

soil vs. corn kernel populations, S124

at-tassel fungicide application and, S49

variation in competitive ability among isolates, 150

in vivo vs. in vitro aflatoxin production, S103

Aspergillus section Nigri on, S10

Bacillus thuringiensis (Bt) proteins in, $\mathrm{S} 183$

Cercospora spp. on, S117, S202

Cochliobolus heterostrophus on, S114

Colletotrichum graminicola on, S19

distillers wet grains, microbial characterization of, S181

drought stress of, S57

for ethanol production, Fusarium toxins in, S180

foliar diseases of, multiple disease resistance and, 72
Fusarium spp. on

F. moniliforme, $\mathrm{S} 4$

$F$. verticillioides: characterization of genes regulating colonization, S148; FB1 translocation in seedlings infected with, S147; FvNoxR gene of, S44; in Nigeria, S117; nitric oxide detoxifying flavhemoglobin and, S10; polyketide biosynthetic gene clusters in, S18

hail-damaged, S34, S109

hypersensitive response of, S11

impact of cropping sequence on, S20

influence of foliar fungicides on components of grain yield in, $\mathrm{S} 132$

Maize streak virus in, 1138, S113

modification of chitinase of by Stenocarpella maydis, 645

nematodes in, in Nebraska, S182

Pantoea agglomerans on, S119

Pantoea stewartii on, S27, S85, S188

plant-parasitic nematodes in, S180

Pratylenchus penetrans on, S184

Puccinia polysora on, S27

Rhizoctonia solani on, 172, S4

Sporisorium holci-sorghi on, S36

Stenocarpella spp. on, in Brazil, S36

at-tassel fungicide application on, S5, S49

Zearalenone, in corn for ethanol production, S180

Zearfoss, A. D., S144, S204

Zebra chip

Candidatus Liberibacter solanacearum on

potato and, S50, S135

overview of, S203

Zelaya-Molina, L. X., S191

Zelenev, V. V., 593

Zellermann, E., S22

Zellner, W. L., S144

Zenbayashi, K. S., S63

Zeng, Q., S64, S68, S75, S144

Zernova, O. V., 897

Zhai, L., S145

Zhan, J., 855

Zhan, S.-W., 436

Zhang, A. B., S89

Zhang, C., S96, S164, S187

Zhang, G., S145, S182, S191

Zhang, H., 328, 822

Zhang, J., S139, S146

Zhang, J. B., 183

Zhang, L., S138

Zhang, M., S145
Zhang, M. Q., 239

Zhang, N., S90

Zhang, P., S73

Zhang, S., S145, S146, S178

Zhang, X., S68

Zhang, Z., 328, S38, S151, S192

Zhao, D., 573

Zhao, W., S23

Zhao, Y., 192, 573, S29, S69, S80, S104, S133,

S135, S206, S207, S208

Zheng, D., S107

Zheng, Y., S3, S53, S146

Zheng, Y. L., 1276

Zhong, S., 1007, S4, S69, S104, S189

Zhou, C., S146

Zhou, G., 313, S132, S140, S146

Zhou, J., S128

Zhou, L., S41, S190

Zhou, L. J., 239

Zhou, M., S23

Zhou, M. G., 522

Zhou, S., S75

Zhou, X., S52, S139, S146

Zhou, X. C., 313

Zhu, S. S., 1162

Zhu, X.-Q., 997

Ziebell, H., S70, S147

Ziems, A. D., S187

Zimba, P. V., S43

Zimmerman, B. H., S39

Zinnia, powdery mildew on, S74

Ziska, L., S179

Ziska, L. H., S208

Zitomer, N. C., S147

Zitter, T. A., S147

Ziv, G., 97

Zot gene

expression rate of in Xylella fastidiosa, S116 for identification of Xylella fastidiosa subspecies, S115

Zou, W.-C., S96

Zoysia spp. (zoysiagrass)

Exserohilum sp. on, in Texas, S57

Rhizoctonia solani on, S91, S203

Zuñiga-Davila, D., S20

Zucchini lethal chlorosis virus (ZLCV), in cucurbits, S87

Zuluaga, A., S147

Zwingman, M., S147

Zwonitzer, J., S114

Zwonitzer, J. C., 72 